\title{
A Libertarian Critique of University Restrictions of Offensive Speech
}

\author{
David F. McGowan $\dagger$ \\ Ragesh K. Tangrił
}

This Comment examines the constitutionality and desirability of university restrictions of offensive speech. The Comment first looks at the turmoil that has prompted campuses to seek ways to maintain a level of civility which will protect students from offense. The Comment then analyzes current theories of protecting speech and, with a few modifications, advocates the use of the skepticism embodied in the metaphor of a marketplace of ideas as a basis for judging both the constitutionality and the desirability of campus speech regulations. The reliance on marketplace skepticism is justified by the relative risk of ceding power to determine truth to the government rather than allowing each individual to make such determinations. The Comment then examines three analytical structures adopted by universities in an effort to maintain civility in speech on campus: regulations designed to prevent violence, regulations designed to prevent offense, and regulations designed to protect the objects of derisive speech from being "stigmatized" by the derision. The Comment concludes that only regulations designed to prevent violence are both permissible under the Constitution and good policy for universities to pursue.

\section{INTRODUCTION}

Thirty-seven years after Brown v. Board of Education, ${ }^{1}$ the country contimues to battle racism. The unanimous edict of the Supreme Court could not erase it from the national conscience. Instead we are forced daily to ask whether we really have made progress in resolving the

$\dagger$ Law clerk, Judge A. Raymond Randolph, United States Court of Appeals for the District of Columbia Circuit. B.A. 1986, University of California, Los Angeles; J.D. 1990, Boalt Hall School of Law, University of California, Berkeley. The views expressed here are the author's alone, and do not necessarily represent the views of Judge Randolph or any other person.

$\ddagger$ B.A. 1986, University of California, Berkeley; J.D. candidate 1991, Boalt Hall School of Law, University of California, Berkeley.

The authors wish to thank Professors Paul J. Mishkin and Robert C. Post for their efforts to educate us about the first amendment. We would also like to thank Ms. Laura M. Craska and Mr. Miehael Mundaca for efforts to bring clarity and support to our arguments. Failings that remain in any of those areas are ours alone. Finally, we would like to thank Messrs. Page and Goldberg for their heroic efforts to reduce this Comment to one final, printed, and timely forn.

1. 347 U.S. 483 (1954). 
American dilemma, or whether we are fooling ourselves through selective observation of our social condition. And who is to say? Twentyeight years later, Mississippi is still trying to convict Medgar Evers' assassin. $^{2}$

Those who are optimistic about progress in race relations have been confronted of late with soine especially disturbing news. Colleges and universities around the country have seen a startling increase both in reported student use of racist, sexist, homophobic, and other spiteful speech, and in the offensiveness of such speech. ${ }^{3}$ Student claims that speech deineaning certain groups harms group ineinbers so severely that its use inust be purished, coinbined with the schools' almost palpable outrage at the use of invective by the relatively well-educated, have proinpted many colleges and universities severely to restrict the use of offensive speech. These institutions have thus becoine the proving ground for new challenges to the first ainendinent.

The censor's role sits ill with inany in the acadeiny, however, and colleges and universities sometimes seem to have no idea how to remain true to their ideals while still addressing the problem. The result has been a variety of codes and regulations based upon an even wider variety of thought. Some campuses have adopted regulations that prohibit students from using "fighting words," a term of art that originated in Chaplinsky v. New Hampshire, ${ }^{4}$ and denotes speech outside the realm of first amendinent protection. Originally ambiguous in scope, the doctrine as narrowed by the Supreine Court covers only speech that is likely to cause the histener to do violence (or at least want to do violence) to the speaker. ${ }^{5}$ The University of California's offensive speech regulation typifies this approach. ${ }^{6}$ The fighting words prohibition is necessarily narrow, however, ${ }^{7}$ and soine campuses have sought to broaden its scope to include references to certam specified characteristics such as ethinicity or sexual orientation. This approach seeks to punish a broader array of speech while maintaining the face-to-face limitation of the fighting words doctrine. A regulation recently adopted at Stanford typifies this

2. See Mississippi Turning; Bizarre Events, Twists May Culminate in Revival of the Medgar Evers Murder Case, L.A. Times, Jan. 16, 1991, at E1, col. 2.

3. See infra text accompanying notes 16-24.

4. 315 U.S. 568,572 (1942).

5. See Lewis v. City of New Orleans, 415 U.S. 130, 132-34 (1974); Gooding v. Wilson, 405 U.S. 518, 522-23 (1972). Both cases involved the use of profanity by African American defendants against police officers. Some have argued that the race of the speaker should immunize the defendants' speech in such circumstances. See infra notes 290-91 and aceompanying text.

6. See Office of the President, University of California, Universitywide Student Conduct: Harassment Policy (Sept. 21, 1989) [hereinafter U.C. Harassment Memorandum] (amending Policies Applying to Campus Activities, Organizations, and Students, pt. A, § 51). For a discussion of this regulation, see infra text accompanying notes 94-97.

7. See infra text accompanying notes 11430 . 
approach, ${ }^{8}$ as does the regulation adopted by the University of Wisconsin. ${ }^{9}$ The ACLU of Northern Califorma also advocates a form of this broader approach. ${ }^{10}$ Some universities have tried an even broader approach that seeks both to regulate speech that tends to "stigmatize" niembers of specified groups and to prohibit speech that offends a histener or incites a violent response. This approach was advocated and abandoned at Stanford. ${ }^{11}$ The University of Michigan adopted this approach and enforced a regulation based upon it until a district court held that the regulation was unconstitutionally vague and overbroad. ${ }^{12}$

This Comment argues that only two very narrow forms of offensive speech regulations are constitutional. ${ }^{13}$ These regulations are of the first type and track generally the fighting words exception, though we argue that offensive nonpublic speech also nray be regulated, even if it does not threaten to cause violence (an issue Chaplinsky did not address). We believe that regulations of the second and third types are unconstitutional.

\section{I}

\section{The Nature of The Problem}

I issue a solemn warning that it is the policy of my adninistration to take action against those who imcite hatred.... It is my intention to prosecute vigorously, and to expel immediately, such individual or nidividuals for any atteinpt to inject or proinote racism and thus insult the dignity of our

8. See Stanford University Student Conduct Legislative Council, Fundamental Standard Interpretation: Free Expression and Discriminatory Harassment (Apr. 19, 1989) [hereinafter Fundamental Standard Interpretation] (Proposed interpretation of Stanford's Fundamental Standard), reprinted in Stanford U. Campus Rep., Apr. 19, 1989, at 22. The proposal was enacted May 24, 1990, effeetive June 11, 1990. Stanford News, Press Release (May 30, 1990). For a defense of the Stanford regulation by its drafter, see T. Grey, Civil Rights vs. Civil Liberties: The Case of Discriminatory Verbal Harassneent 15-16 (1990) (unpublished manuscript) (on file with authors).

9. See UW News, UW Racism Rules Expected to Take Effect in Septenber, Press Release (July 21, 1989) [heremafter U.W. Racism].

10. See American Civil Liberties Union of Northern California, ACLU-NC Policy Concerning Racist and Other Group-Based Harassnent on College Campuses (approved Dec. 14, 1989 and amended Jan. 11, 1990).

11. See Scholars See Flaws in Amendment to Code of Conduct, Stanford U. Campus Rep., Mar. 15,1989 , at 1 .

12. See Doe v. University of Mich., 721 F. Supp. 852, 866-67 (E.D. Mich. 1989).

13. This Comment will limit its scope to the regulation of speech at universities subject to the first amendment; namely, public universities. Many private universities attempt voluntarily to conply with the first amendment. See, eg., Council Proposes Fundamental Standard Additions, Stanford U. Campus Rep., Apr. 19, 1989, at 21 (discussing Stanford's policy on limiting free speech) [hereinafter Council Additions]. Illinois Representative Henry Hyde has introduced a bill in Congress that would require private universities to comply with the requirements of the first amendment. $A C L U$ Joins Hyde in Free-Speech Fight, Chicago Tribune, Mar. 12, 1991, at 6, col. 1 [hereinafter Free-Speech Fight]. 
students as citizens of Brown. ${ }^{14}$

-Vartan Gregorian, President, Brown University

I think it was just a pohtical statenient by the University. ${ }^{15}$

-Douglas Hann, commenting on his expulsion by Brown University

Douglas Hann used to play football and attend classes at Brown. He celebrated his twenty-first birthday in part by yelling racial insults and obscenities at no one in particular, apparently simply for the sake of donig so. When sonie students objected to his behavior, he seized the opportunity for a inore specific use of nivective. ${ }^{16} \mathrm{Mr}$. Hann no longer attends Brown, having the dubious privilege of being the first student in the country expelled for the stated reason that his speech was intolerably bad. ${ }^{17} \mathrm{Mr}$. Hann is alone only in his fate, however. In Fall 1988, three Stanford students had an argunient in which one clainied that Beethoven had African ancestors. ${ }^{18}$ Two of the students, later described by the New York Times as "drunken freshmen,"19 defaced a synıphony recruiting poster into a black-face caricature of Beethoven and placed it near the dormitory room of the African American student with whon they had been arguing. ${ }^{20}$

The incident received national attention, and drew attention to racist incidents at inany campuses across the country. ${ }^{21}$ Other incidents

14. Student at Brown is Expelled Under a Rule Barring 'Hate Speech'' N.Y. Times, Feb. 12, 1991, at A17, col. 1.

15. Id.

16. See Speech Code at Issue in Brown Case, Wash. Post, Feb. 13, 1991, at A4, col. 2.

17. President Gregorian wrote an editorial during the final stages of editing on this Comment denying that Hann was expelled for his speech. See Gregorian, Free Speech? Yes. Drunkenness? No., Wash. Post, Apr. 3, 1991, at A23, col. 2. President Gregorian pointed out that Brown has no speech policy as such. Hann, he said, was expelled for violating the university's general code of conduct. The editorial leaves unanswered, however, the key question: whether Hann would have been expelled had his speech been less offensive. President Gregorian characterized Hann's speech as "obscenities," which, at least in the legal meaning of the word, they were not (unless one assumes epithets appeal to a prurient interest). President Gregorian also enuphasized that Hann's behavior was "harassimg" and "imtimidating" and thus in violation of Brown's Tenets of Community Behavior.

All this nay well be true, but it says nothnig about the frec speech issue. One inay intimidate or harass by giving a confroversial speech on the front lawn or by throwing garbage on the neighbor's roof. The effect inay be the same-the neighbor is intinidated or annoyed-but only in the former case is there a constitutional question. Referring solely to the annoyance listeners feel simply begs the question.

18. Stanford U. Campus Rep., Apr. 12, 1989, at 1.

19. Barringer, Campus Battle Pits Freedom of Speech Against Racial Slurs, N.Y. Times, Apr. 25, 1989, at A1, col. 1. [hereinafter Campus Battle] (detailing the Stanford incident).

20. Id.

21. See Smolla, Rethinking First Amendment Assumptions About Racist and Sexist Speech, 47 WASH. \& LEE L. REv. 1, 7-8 (1989) (detailing several racist incidents); see also Matsuda, Public Response to Racist Speech: Considering the Victim's Story, 87 MicH. L. REv. 2320, 2333 n.71 (1989) (collecting incidents that occurred in 1987-88); College Campuses Reinforce Rules Barring Racism, 
ranged in severity from the on-air use of racial jokes at the University of Michigan campus radio station to an interracial brawl at the University of Massachusetts. ${ }^{22}$ Prior to Mr. Hann's expulsion, racist graffiti at Brown was cited as a partial cause of several assaults on whites. ${ }^{23}$ At the Umversity of California at Berkeley, a drunken "freshman fraternity pledge uttered a series of offensive racial and sexist epithets at four fresman [sic] residents . . p passing by his wimdow," and a disc jockey at a residence hall party responded to requests to play rap music by announcing that those wishing to hear such inusic should "go back to

San Francisco Chron., Sept. 18, 1989, at A1, col. 1 (detailing racist incidents at U.C. Berkeley and Stanford).

At the risk of persuading the reader persistent enough to delve into so foreboding a footnote that we could not possibly have anything new, much less worthwile, to say, candor coinpels us to acknowledge that oceans of ink have been spilled in this debate. Readers wishing further material on the topic may see, for example, Arkes, Civility and the Restriction of Speech: Rediscovering the Defamation of Groups, 1974 SUP. CT. REV. 281 (reviewing Supreme Court decisions regarding group libel); Byme, Racial Insults and Free Speech Within the University, 79 GEo. L.J. 399 (1991); Delgado, Campus Antiracism Rules: Constitutional Narratives in Collision, 85 Nw. U.L. REv. 343 (1991) [hereinafter Delgado, Constitutional Narratives]; Delgado, Words That Wound: A Tort Action for Racial Insults, Epithets, and Name-Calling, 17 HARV. C.R.-C.L. L. REV. 133 (1982) [hereinafter Delgado, Words That Wound] (arguing for a tort action to redress racial insults); Heins, Banning Words: A Comment on "Words That Wound," 18 HARv. C.R.-C.L. L. REv. 585 (1983) (arguing against a tort action for racial insults as contrary to the first amendinent); Kretzmer, Freedom of Speech and Racism, 8 CARDozo L. REV. 445 (1987) (arguing for regulation of racist speech); Lasson, Group Libel Versus Free Speech: When Big Brother Should Butt In, 23 DuQ. L. REv. 77 (1984) (arguing that racial defamation does not merit first amendunent protection); Walker, The First Amendment and Current Proposals to Outlaw Racist Speech and Organizations: What Would Engels and Lenin Say?, 44 GuILD PRAC. 124 (1987) (arguing from a Marxist perspective for regulation of genocidal speech but rejecting any undermining of the first amendment); Note, $A$ First Amendment Justification for Regulating Racist Speech on Campus, 40 CASE W. RES. L. REV. 733 (1990) (authored by Deborah R. Schwartz); Note, Racist Speech, the First Amendment, and Public Universities: Taking a Stand on Neutrality, 76 CORNELL L. REV. 549 (1991) (authored by David Rosenberg); Note, A Communitarian Defense of Group Libel Laws, 101 HARV. L. REV. 682 (1988) [hereinafter Note, Communitarian Defense] (arguing that group hibel laws do not violate the first amendment); Note, The Call for Campus Conduct Policies: Censorship or Constitutionally Permissible Limitations on Speech, 75 MINN. L. REv. 201 (1990) [hereinafter Note, Campus Conduct Polieies]; Note, Racist Speech on Campus: A Title VII Solution to a First Amendment Problem, 64 S. CAL. L. REV. 105 (1990) [hereinafter Note, Title VII Solution] (authored by Ellen E. Lange); Note, Group Vilification Reconsidered, 89 YALE L.J. 308 (1979) [hereinafter Note, Group Vilification] (arguing tlrat group defamation causing "serious harm to public interest" can be banned under the first amendinent); Discussion, Alan Borovoy and Kathleen Mahoney speaking, Barry Brown, Jamie Cameron, David Goldberger and Mari Matsuda commenting, The James McCormick Mitchell Lecture series, Law School of the State University of New York at Buffalo (Nov. 4, 1988), edited transcript reprinted as Language as Violence v. Freedom of Expression: Canadian and American Perspectives on Group Defamation, 37 BuFfalo L. REV. 337 (1988) (discussing Canadian "antihate" laws and analogous American regulations); T. Grey, supra note 8.

Many of these same issues were being discussed four decades ago in the debate over group libel laws occasioned by the Nazi rise to power. See, e.g., Riesinan, Democracy and Defamation: Control of Group Libel, 42 CoLUM. L. REv. 727 (1942) (discussing the possibility of group hibel laws from an anti-fascist perspective).

22. See Campus Battle, supra note 19, at A20, col. 1 .

23. Hamill, Black and White at Brown, EsQurRe, Apr. 1990, at 67-68. 
Oakland.' "24

In addition to denouncing the instigators of these incidents and the racism underlying the instigators' conduct, ${ }^{25}$ several campuses adopted speech regulations designed to prevent such incidents froin recurring. ${ }^{26}$

24. A. Kolling, Assistant to the Dean, Office of the Dean of Academic Programs, University of California at Berkeley, Racial Harassment Issues 2-3 (Oct. 23, 1989) (memorandum to Prof. Tom Leonard, Chair of the Committee on Academic Freedom, setting forth an outline of racial harassment issues in anticipation of the ineeting of the Committee on Academic Freedom). The memorandum states that the examples of racial harassment set forth "are not the only complaints resolved in recent years but certainly typify the range of grievances that come to [the Committee's] attention." Id. at 3.

25. See, e.g., Campus Battle, supra note 19. Offensive speech on campus is not limited to racist or sexist comments. In perhaps the most bizarre imcident, the editor of a student newspaper at Geneva College in Beaver Falls, Pennsylvania, wrote and published an editorial arguing that by allowing the teachings of Cardimals and the Pope to "supersede Scripture," the Catholic Church was violating the true teachings of God and so dooming its inembers to damnation. Student Newspaper Closed Over Editorial, Pittsburgh Post-Gazette, Mar. 29, 1990, at 1, col. 2. The editorial, entitled Theology of the Pointy Hats, referred to the Pope and Cardinals of the Catholic Church as "pointy hats." Id. Understandably, the piece offended many Catholic students at the college (Catholics make up about $20 \%$ of the college's student body). Id. The student editor asserted that the views put forth in the editorial were consistent with those of the Reformed Presbyterian Church, with which the college is affiliated (although Reformed Presbyterians make up only $4 \%$ of the student body). Id. The Student Publieation Board ordered the newspaper closed for the remainder of the semester, although a campus spokesperson sought to assure the campus that "the suspension of the publication was not intended to censor." Id. at 10, col. 1.

Another such controversy erupted as this Comment was going to press. See Himmelstein, Article on Blacks' Credentials Spurs Law-School Flap, Legal Times, Apr. 15, 1991 at 1, col. 4. A student at the Georgetown University Law Center published in a campus paper an article claiming that minority students' scholastic achievements were inferior to those of nonminority students. Id. at 1, col. 4, 9, col. 1. The author offered the results of a "random sample" of LSAT scores in support of his assertion, having obtained the scores during the course of his employinent in the school's admissions office. Id. at 10, col. 3. The article was not well received, and there were calls for the author's expulsion. Id. at 9, col. 2. The criticism seemed to focus generally on the propriety of making such a statement, and more specifically on the quality of the author's statistical methodology, as well as his alleged breach of confidentiality in revcaliug applieant file information (possibly in contravention of the terms of his employment). Id. at 9, col. 1-4, 10, col. 3.

We lack the information necessary to evaluate the accuracy of the second claim, and much of the third. It secms uncontroversial that if the author violated a term of his employinent, he is subject to discipline as an employee. Furthermore, if Georgetown's student code includes a provision subjecting to expulsion a student who engaged in certain forms of prohibited conduct, and doing so regardless of whether such conduct is related to his capacity as a student, the only relevant question is whether the author's conduct (i.e., violation of an employinent rule regarding the privacy of records) would justify his expulsion if he worked for a private law firm and had improperly used his access to case files. What ought to be irrelevant to the above inquiry is the content of the assertions made in the article, as well as the methodological validity of the author's "survey" of LSAT scores. As argued at infra text accompanying notes $48-68$, if the first amendment does nothing else it requires that speech not be punished simply becanse it is "wrong."

26. It is difficult to be certain how many campuses have adopted restrictions on offensive speech. The Carnegie Foundation estimates that $70 \%$ of colleges and universities have adopted regulations restricting the use of offensive speech. Free-Speech Fight, supra note 13, at 6 . Through the kindness of Professor Robert C. Post, we have been able to review regulations from the following: Califorma Polytechuric University at Pomona, Canisius College, Central College (Iowa), Clark University, Dartmouth College, Edinboro University (Pennsylvania), Emory University, Hampshire College, Harvard University, Haverford College, Iowa State University, Kent State 
Perhaps the broadest and certainly the best-publicized regulation was adopted by the University of Michigan. A federal district court held the regulation unconstitutional as both vague and overbroad. ${ }^{27}$ At the risk of frightening the wary reader nito thinking this is yet another casenote (and an appallingly long one at that), a brief examination of Michigan's experience in implementing its regulation may help delineate the problems presented by offensive speech regulations.

The University of Michigan suffered a spate of racist mcidents on campus during Spring $1987 . .^{28}$ It adopted a policy designed to ensure that such behavior would not recur. The broadly written policy generally prohibited not only abusive behavior but also behavior either that had the foreseeable effect of "interfering" with another student's "participation" in campus life or that created a "hostile environment." 29 The policy provided for inforinal niediation procedures as well as formal hearings if any nember of the university community filed a complaint. ${ }^{30}$ The penalties for violations of the policy ranged from reprimand to expulsion. ${ }^{31}$ A graduate student in biopsycliology challenged the policy. ${ }^{32}$ Doe, who was also a teaching assistant, stated that lie wanted to teacl "certam controversial theories positing biologically-based differences between sexes and races," $" 33$ but feared that domg so would niake

University, Loyola University (Illinois), Marquette University, Massachusetts Board of Regents of Higher Education, Massachusetts Institute of Technology, Merrill College (University of California at Santa Cruz), Michigan State University, Mount Holyoke College, Northwest Missouri State University, Oberlin College, Pennsylvania State University, Rutgers University, Stanford University, State University of New York (Colleges at Brockport and Cortland), the University of California system, the University of California at Berkeley, the University of California at Los Angeles, the University of Connecticut, the University of Massachusetts at Amherst, the University of Michigan, the University of Pennsylvania, the University of Southern California, the University of Texas, the University of Wisconsin, Wesleyan College (Counecticut and West Virginia), West Chester State College (Peunsylvania), and Willians College).

27. Doe v. University of Mich., 721 F. Supp. 852, 861-67 (E.D. Mich. 1989).

28. Id. at 854-56.

29. Id. at 856 . The policy, in pertinent part, provided that persons were subject to discipline for:

1. Any behavior, verbal or physical, that stigmatizes or victimizes an nidividual on the basis of race [or] ethnicity .... and that

a. Involves an express or inphied threat to an individual's academic efforts, employment, participation in University sponsored extra-curricular activities or personal safety; or

b. Has the purpose or reasonably foreseeable effect of interfering with an individual's academic efforts, eniployment, participation in University sponsored extra-curricular activities or personal safety; or

c. Creates an intimidating, hostile, or denieaning environnent for educational pursuits, employment or participation in University sponsored extra-curricular activities.

Id. (quoting University of Michigan, Policy on Discrinination and Discriminatory Harassnent of Students in the University Environinent).
30. Id. at 857 .
31. Id.
32. Id. at 858 .
33. Id. 
him liable to sanction under the policy. ${ }^{34}$

The district court first considered the possibility that certain forms of racist speecli could fall into one of the unprotected categories of speech (figliting words, emotional distress, or group libel). ${ }^{35}$ The court concluded that the university could not prohibit racist speech either because it disagreed with the speech, or because large numbers of people found it offensive. ${ }^{36}$ The court then found that the umiversity had in the past applied the policy in various contexts: classrooin discussions concerning the inorality of hoinosexuality; the use of a hoinophobic limerick in a classroon; a classrooin assertion that the speaker had heard that minorities had a difficult time in a particular course; and others. ${ }^{37}$ The court noted that even though the university had not formally punished all the students involved, it had forced then all to endure disciplinary hearings, and had attenupted to persuade then submit to what the court characterized as "voluntary' sanctions."38 Based on these facts, the court found that the university had apphed the pohicy to prohibit constitutionally protected speech. ${ }^{39}$ The court concluded that because the policy left substantial doubt as to what sort of speech would and would not be punished, it was likely to have a substantial chilling effect on protected speech, and thus was impermissibly vague. ${ }^{40}$

Doe inakes clear that the fatal constitutional flaws of the Michigan regulation were its vague definition of what speech would be actionable and its overly broad apphication. Because the court found Michigan's policy so obviously deficient, however, Doe did not address the sort of questions that need to be answered to determine what types of regulations could be permissible: What type of speech can be regulated? What type of speech inust renain protected? How does one distinguish between the two? In alluding to these inore abstract issues, the district court frained the issue as a conflict between "the ideals of freedom and equality."41 Many commentators have franied the issue in a like manner, alternatively referring to a conflict between civil rights and civil liberties, ${ }^{42}$ or between coininunitarian and libertarian values. ${ }^{43}$ Sonie con1mentators, however, deny the existence of any such conflicts, asserting that "[r]acist speech is best treated as a sui generis" that is, "outside the

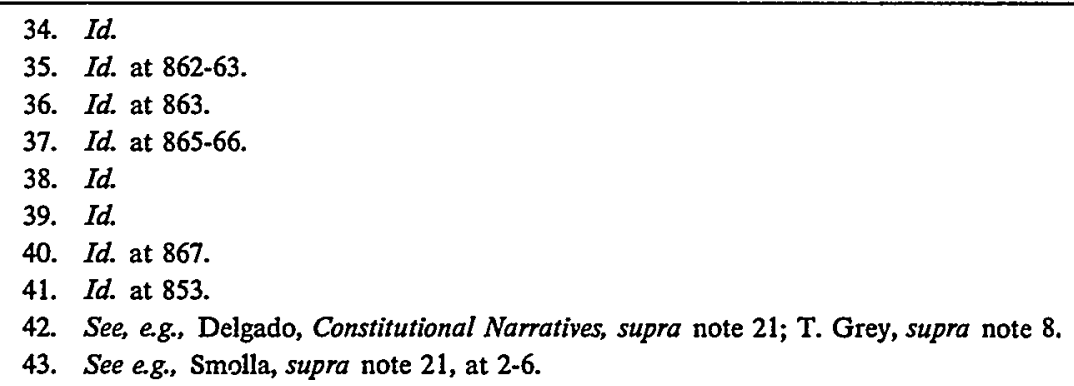


realm of protected discourse." ${ }^{44}$ Such attempts can succeed only if one is able to justify treating racist speech as a qualitatively unique category of speech undeserving of first amendment protection. We address the efforts in this regard below; ${ }^{45}$ for now, we may treat the argument as recognizing the potential for conflict but believing that in the case of offensive speech there is in fact no conflict.

Underlying these more abstract issues is the largely undebated question of how these regulations affect the students who must abide by them. As the quotation beginning this Section indicates, Douglas Hann obviously did not see the larger principle embodied in his expulsion and, though he is not an especially appealing advocate for the view, it is possible to argue that campus speech regulations are more a sigu that a given university has acceded to minority pressure groups and feels a need to affirm its hberal credentials by expelling the odd offensive or "incorrect" student than they are a reflection of a larger principle. Others doubtless perceive such regulations as the absolute minimum the acadeniy owes the students against whon it once discriminated.

Before attenipting to wade through such an imposing thicket of issues, however, we nuust first pause briefly to examine the theoretical underpinnings of the first amendnient, and the implications various first amendinent theories have for the regulations outlined above. Until we know why we protect speech we cannot talk intelligently about whether any given effort to constram speech is dangerous. Adherence to flawed premises distorts the intellectual cliniate of the university; implenientation of such premises through the regulation of speech would simply be perverse.

II

\section{THEORIES OF SPEECH}

Modern theories justifying the freedoin of speech are dominated by a utilitarian vision: we protect speech because it is necessary to achieve sonie greater, often ultimate, social good. Professor Greenawalt describes such utilitarian argunients as "consequentialist."46 $\mathrm{He}$ contrasts these with "nonconsequentialist argunients," which hold that speech is good per se. ${ }^{47}$ We may set the latter to one side for the noment; non-consequentialist arguments are both less widely recognized by courts deciding first amendinent cases and nore difficult to analyze. Three consequentialist argunients are pertinent to university regulations of offensive speech: the argunient fron truth, the argument from

44. Matsuda, supra note 21 , at 2357.

45. See infra text accompanying notes 357-62.

46. Greenawalt, Free Speech Justifications, 89 Colum. L. Rev. 119, 127-30 (1989).

47. Id. 
democratic self-governance, and the argument from tolerance. We address last the only nonconsequentialist argument relevant to such regulations: the argument from autonomy or self-realization.

\section{A. Consequentialist Arguments for Protecting Speech}

Modern consequentiahst first amendment reasoning derives largely from Mill's defense of free expression. Keeping in mind Professor Shiffrin's warning that Mill has been blamed for saying a lot of stupid things he never said, ${ }^{48}$ we begin with the role of speech in discovering truth.

\section{Speech in the Marketplace of Ideas}

Holmes, who was acquaimted with Mill, ${ }^{49}$ introduced the metaphor of "the marketplace of ideas" into first amendment jurisprudence in his famous dissent in Abrams v. United States:

Persecution for the expression of opinions seems to me perfectly logical. If you have no doubt of your premises or your power and want a certain result with all your heart you naturally express your wishes in law and sweep away all opposition. To allow opposition by speech seems to indicate that you think the speech inipotent, as when a man says that he has squared the circle, or that you do not care whole-heartedly for the result, or that you doubt either your power or your premises. But when men have realized that time has upset many fighting faiths, they may come to beheve even more than they beheve the very foundations of their own conduct that the ultinate good desired is better reached through free trade in ideas-that the best test of truth is the power of the thought to get itself accepted in the coinpetition of the market, and that truth is the only ground upon which their wishes safely can be carried out. That at any rate is the theory of our Constitution. It is an experiment, as all life is an experiment. ${ }^{50}$

Holmes' premise is that any idea might be true, and therefore suppression of ideas might cause the suppression of truth. The premise as stated would include, of course, racist ideas. Holmes' premise has carried the day in first amendment jurisprudence, which currently recognizes "no such thing as a false idea." 51 Neither the premise nor the

48. Shiffrin, The First Amendment and Economic Regulation: Away From a General Theory of the First Amendment, 78 Nw. U.L. REV. 1212, 1261-62 (1983).

49. S. Novick, HoNorable JUSTICE 105-06 (1989).

50. Abrams v. United States, 250 U.S. 616, 630 (Holmes, J., dissenting).

51. Gertz v. Robert Welch, Inc., 418 U.S. 323, 339 (1974). The passage was dicta, but has animated a crucial distinction in defamation law ever since it was written. The full passage reads:

We begin with the common ground. Under the First Amendment there is no such

thing as a false idea. However peruicious an opinion may seem, we depend for its correction not on the conscience of judges and juries but on the competition of other ideas. But there is no constitutional value in false statements of fact. 
conclusion, however, is indisputable or even ultimately persuasive. Even if one assuines that truth is an absolute good, ${ }^{52}$ the argument is difficult to inaintain.

Initially, the premise appears by its terms limited to a discourse of ideas distinct froin statements of fact. ${ }^{53}$ There are certain stateinents that we accept as true and, therefore, except from the ambit of the inarketplace theory-even if such acceptance reflects nothing more than our shared interpretation of certain uses of language. ${ }^{54}$ In other words, we consider some stateinents sufficiently verifiable that we do not need to be skeptical about whether some other statennent might actually be the truth; we accept that we have a way definitively to resolve any dispute. If I say the temperature is 100 degrees, the reader may safely rely upon a thermometer if she wishes to check whether I am mistaken. To borrow an exainple froin Professor Post, a statement about the weather on a date hundreds of years ago is perceived as factual even though it cannot be verified today. ${ }^{55}$ The decision to suspend skepticisin about such speech coinports with the Court's view that "there is no constitutional value in false stateinents of fact." 56

Id. at 339-40 (footnote omitted).

Because a libel plaintiff must prove that the allegedly libelous statenent was false (truth being an absolute defense), Philadelplia Newspapers, Inc. v. Hepps, 475 U.S. 767, 775 (1985), Gertz makes crucial, and often dispositive, the characterization of a statenent as one of fact or of opinion. This ineffable distinction lias plagued courts and commentators, and lias spawned quite intricate efforts to articulate rules that will allow for consistent adjudication. See, eg., Post, The Constitutional Concept of Public Discourse: Outrageous Opinion, Democratic Deliberation, and Hustler Magazine v. Falwell, 103 HARV. L. REv. 603, 649.66 (1990) (arguing that the distinction between fact and opinion or ideas can be most convincingly explained by sliared social interpretations of certain forms of speech). On the whole, the Court has more or less adroitly sidestepped the issue by rejecting the "artificial dichotomy" between fact and opinion in defamation actions, while still requiring proof of falsity for the plaintiff to prevail. See, e.g., Milkovich v. Lorain Journal Co., 110 S. Ct. 2695, 270506 (1990).

52. This assumption is not quite as obvious as it seems. If, for example, one could prove (througl whatever method) that men and women liave differential, biologically determined aptitudes in some area, one could plausibly argue for the suppression of such truth in service of the greater social good of equality.

53. See supra note 51 (discussing fact/opimion dichotomy).

54. Professor Matsuda, for one, claims that statenents of racist theories fall into this category and, therefore, may not be protected by reference to inarketplace theory. Matsuda, supra note 21, at 2359.

55. Post, supra note 51, at 655.

56. Gertz v. Robert Welcl, Inc., 418 U.S. 323, 340 (1974). Gertz appears to depart froin Mill's conception of the argument froin truth: Mill would proteet falsity on the rationale that the marketplace would reveal it to be false, thereby strengthening our confidence in the truth. This departure is, however, more apparent than real. Even under Mill's conception, false statements did not have inlierent value; they were valuable only because they enhanced confidence in the trnth, and because of the value inherent in the process of proving them false. The first amendinent protects some falsity on a similarly utilitarian rationale: Some false statements are tolerated to avoid chilling "speech that inatters." Thus, the point in Gertz is technically correct, if somewhat misleading, in its implieation that false statements of fact are never protected by the first amendinent. 
Even when properly confined to speech articulating ideas, however, a version of the marketplace theory that seeks to justify the freedom of speech as the best way to find objective truth must assume that we will recognize truth when it is presented. The theory offers no criterion for judging truth, however, nor any empirical evidence that truth will be recognized. And there is ample empirical evidence refuting an uncritical reliance on people simply to know truth when they see it. ${ }^{57}$ Indeed, as Justice Holmes' Abrams dissent imphcitly recognized, the inarketplace theory is, at bottom, a process-driven theory. It is an experiment in ascertaining truth and achieving the good society. As a process, however, it offers no view on the ultimate question of what constitutes objective truth other than to say that such trutl, whatever it is, is more likely to emerge from this process than from any other.

One is tempted to skirt this difficulty by arguing that the truth is itself defined by the marketplace-truth is that which comes to be accepted through competition. As a justification, however, the argninent is perfectly circular: We protect speech in order to preserve a marketplace of ideas tliat seeks trutli, "truth" being defined as that which emerges from the marketplace. In otlier words, we create a marketplace to provide us with truth, which we proclaim as such when it is a product of our creation. Worse, a rigidly process-based theory of objective truth sliould make us at least a touch uncomfortable. The Nazis were able to avail themselves of a relatively open marketplace to gam power, ${ }^{58}$ and racism has a lengtlyy history of doininating the marketplace in tlie United States. The poimt for now is simply that we should be reluctant to abandon completely the idea of objective truth in favor of a rationale that is, as stated, so completely circular. We should not read substantive content into a procedural metaphor.

Because marketplace theory is process-based, we must confront anotlier problem: why clioose this process over any competing process? As Professor Scliauer puts it, "[i]f truth is defined by reference to and in terms of a process, then why is the process of open discussion preferable

57. Cf. Jacobellis v. Ohio, 378 U.S. 184, 197 (1964) (Stewart, J., concurring) (discussing the difficulty in defining obscenity but claiming "I know it when I see it"). The analogy to obseenity is, whilc hopefully at least somewhat humorous, a serious one. If the Court were willing, there is no doubt that the U.S. Reports could contain as nany opinions struggling with the fact/opinion problem as they do opinions struggling to separate the obscene from the protected. Just as a given photograph will undoubtedly receive different treatment in different comnunities (Berkeley and Cincinnati come to mind), so will a given statement. See, e.g., Milkovieh v. Lorain Journal Co., 110 S. Ct. 2695, 2709-11 (1990) (Brennan, J., dissenting) (arguing that contrary to the Court's finding, the statenient at issue in that case could not reasonably be interpreted to imply statenients of fact); FCC v. Pacifica Found., 438 U.S. 726, 770 (1978) (Brennan, J., dissenting) (noting that language is interpreted differently in different communities).

58. The Nazis, of course, subsequently closed the narketplace they had utilized. The point here is therefore a narrow one-it applies only to their rise to power, not to their rule. 
to any other process, such as random selection or authoritarian fiat?"59 We may postulate that freedom to argue is a necessary condition to the discovery of truth, even if not a sufficient one, but we still have not solved the problem of extractimg substantive criteria for truth from a processbased theory. Moreover, if we really are seeking truth imstead of merely a congenial process, we would be better off with an omniscient dictator rather than a marketplace of ideas.

This problem is highlighted by what appear to the modern eye to be failures in the marketplace of ideas. Assuming for the moment that we can articulate criteria sufficient to identify objective truth, can we realistically be sure that said truth will prevail in the marketplace? This Comment is written in part because of the historical prevalence of racist ideas in this country, and there are innumerable examples of other nations-from Nazi Germany to South Africa-adopting creeds that modern Americans view as repugnant. As we will explore in greater detail below, these cases often (if not always) reflect more an intentional, governmental distortion of the marketplace than a flaw in the basic theory. Nevertheless, the theory provides no way to defend agamst a population that willingly adopts objectively destructive and repugnant beliefs, and would prohibit the government from regulating agamst them. ${ }^{60}$

All this, lrowever, does not require us to abandon marketplace theory as a justification for free speech. For one thing, by comparatively maximizing the amount of speecli available for consideration, it provides criteria pursuant to which we may test the utility of speecli (as opposed to other activity) in leading to the possible discovery of truth. ${ }^{61}$ More importantly, the skeptical premise of the argument allows us to shift our

59. F. Schauer, Free Speech: A Philosophical EnQuiry 20 (1982).

60. Significantly, however, the theory does not prohibit the government from acting as a participant in the marketplace of ideas and engaging in efforts to alter its citizens' views. See infra notes 461-63 and accompanying text.

61. We here part company with Professor Schauer, who views speech as representing the instantiation of differing "background values," which are comprised of the values commonly associated with consequentialist justifications for free speech. Schauer, The Second-Best First Amendment, 31 WM. \& MaRY L. Rev. 1, 4-5 (1989). Professor Schauer argues that speech is inevitably both underinclusive and overinclusive with respect to each background value. Id. at 7 . With respect to the background value of truth, speech does appear overinclusive: Not all speech is true, nor does it necessarily lead to truth.

We do not agree, however, that speech is underinclusive with respect to truth. To demonstrate this point would require one to isolate things that lead to the discovery of truth but that do not fall within speech as broadly defined by the Court. Apart from divine revelation, which itself would require prior acceptance (doubtlessly gained through speech) of a divinity, we question whether such factors may be isolated. While experience may give us a greater appreciation of certain truths, such as the effects of a certain drug, for example, those truths are knowable in an intelleetual sense only through speech and can be rationally interpreted only through speech. This is the point Orwell made when referring to the ultimate effect of newspeak-when there is no langnage to articulate dissent, it is no longer possible rationally to conceive dissent. One is left with only an undifferentiated, unarticulated feeling of dissatisfaction. As Mill said, it is impossible to separate 
focus to the more relevant question: Even given that imdividual determinations of truth are often suspect, why should we expect the government to do any better? Arguments demonstrating the difficulty of imdividual determinations of objective truth apply with equal, and in fact greater, force to governmental determinations. As Professor Schauer argues, "[a]s imdividuals are fallible, so too are governments fallible and prone to error. Just as we are properly skeptical about our own power to distinguish truth from falsity, so should we be even more sceptical of the power of any governmental authority to do it for us."

Marketplace theory is therefore based in large part upon "the possibility and history of error [that] makes us properly wary of entrusting to any governmental body the authority to decide what is true and what is false, what is right and what is wrong, or what is sound and what is foohsh." ${ }^{63}$ Inevitably, therefore, we are faced with a choice between two imperfect options: Either we leave to each individual the choice of what is true and false, right and wrong, and the like, or we grant to the government the power to make that choice and to enforce its choice by prohibiting dissent. In this sense, we must choose either a free inarket, a command economy of ideas, or some mixture of the two. Simply put, the marketplace theory rests ultimately upon the consummately hibertarian behef that individuals are better judges of what is best for them than is the government. ${ }^{64}$

Marketplace theory therefore rests ultimately upon the relative risks of oppression involved. As between the risk that individuals will choose the "wrong" truth and the risk that government will do so, marketplace theory prefers the former. This preference reflects the government's effective monopoly on the use of "legitimate" force to enforce its view of the truth. If an mdividual imistakeuly believes falsity to be true, she suffers for her imistake. If a government makes the same error, inilhons of people may suffer. To borrow froin Professor Epstein on the larger point:

A fine despot may do wonders for a while: public roads may be constructed, the trains may run on time, and the Dow may reach three thousand. But a bad despot, or a good despot turued bad, has quite the opposite effect. Our concerns go beyond potholes, train delays, and the bear inarket. We worry about tyranny, terror, confiscation, segregation, imprisoninent, and death. There is more to fear from the downside than

liberty of belief from "the cognate liberty of speaking and writing." J.S. MILL, ON LIBERTY 74 (Pengum ed. 1985).

62. F. SCHAUER, supra note 59 , at 34 .

63. Id.

64. For an argument recommending the inarketplace of ideas as the model for economic regulation, see generally Director, The Parity of the Economic Market Place, 7 J. L. \& EcoN. 1 (1964). 
there is to gain from the upside. ... [T] not have equal weight. We should set our presumption against the concentration of power in the hands of the government. Too much power is more dangerous than too hittle. ${ }^{65}$

It is true that the theory gives us no protection from a population that selects Nazism from the marketplace. The unfortunate fact is that no other system would, either. The commumists were to hiberate the people from the czars. But who will hiberate them from the commumists? No system is perfect, nor any perfectly safe. But dispersing the choice of what is true and false doctrine, good and bad pohicy, to the people is ultimately the best hope of avoiding tyranny. Writing of statutory imterpretation, Holmes said: "[I]f my fellow citizens want to go to Hell I will help thein. It's my job."66 If enough people embrace an idea of government, evil or not, they will implement it and no theory can change that. That being said, we may say in favor of the theory that an open marketplace is possibly the only ineans short of war to displace a repugnant ideology. As Judge Easterbrook wrote in striking down the Indianapohs antipornography statute, "Free speech has been on balance an ally of those seeking change. Governments that want stasis start by restrictimg speech. . . . Without a strong guarantee of freedoin of speech, there is no effective right to challenge what is."67

65. Epstein, The Mistakes of 1937, 11 Geo. MASON U.L. REv. 5, 5-6 (1988).

66. 1 HolMES-LASKI LETTERS 249 (M. Howe ed. 1953).

67. American Booksellers Ass'n v. Hudnut, 771 F.2d 323, 332 (7th Cir. 1985), aff'd per curiam, 475 U.S. 1001 (1986). In criticizing Judge Easterbrook's approach in Booksellers, Professor Michelman has launched a frontal assault on the premise that we have more to fear from governmental restrictions on speech than from private restrictions on speech. As he puts it, "[w]e simply cannot say, a priori, that either avenue of social action-state or market-is categorically safer than the other." Michelman, Conceptions of Democracy in Ameriean Constitutional Argument: The Case of Pornography Regulation, 56 TENN. L. REv. 291 (1989). Michelman is right to some extent. There is nothing inherent in the concept of the state that compels actual governments to act tyrannically. It seems to work out that way, sometimes to a greater and sometimes to a lesser extent. Public choice theorists would have hittle trouble concluding that legislators would seek to constrain dissent to solidify their own position and maximize their staying power. Whatever the cause, however, at some point it seems counterproductive to ignore such an extensive history of governmental suppression of speech $\mathrm{m}$ order to justify the pursuit of a vision of perfect equality.

According to Professor Michelman, however, if we accept that allowing the distribution of pornography in the marketplace will silence some women, either effectively by causing men to disregard their speech, or hiterally by creating a social atmosphere in which women are imtimidated imto not speaking, then there is no reason to assume that regnlation of pornography is actually a greater limitation of speech than is leaving the inarket free. Id. at 313. For all but purely philosophical purposes it is enough to note, as Professor Michelman concedes, id. at 307, that the first amendment only prohibits Congress froin regulating speech, and the fourteenth amendment only prohibits states from doing so. Assuming that a court could get around this language, however, we still find Professor Michelman's point unpersuasive.

Professor Michelman argues that there is no reason to assume that legislation will fail to reflect the trne interests of all persons in society, including women oppressed by pornography. He argnes that legislative intrusions in the marketplace of ideas might well be safer than the asserted alternative of private suppression so long as the legislation is adopted pursuant to "deliberative politics." Id. at 
Thus, though we have come a long way from Abrams, Holmes' approach remains sound. We need only replace the notion that the marketplace will yield objective truth with the extension of the argument's skeptical premise to government officials seeking to regulate speech. Under this view then, "the first annendment is not the reflection of a society's highest aspirations, but rather of its fears, being simultaneously the pessimistic and necessary manifestation of the fact that, in practice, neither a population nor its authoritative decisionmakers can even approach their society's most ideal theoretical aspirations." 68

\section{Free Speech and Democratic Self-Governance}

The argument from truth shares center stage with the argument that freedom of speech is a necessary prerequisite to democracy. Professor Greenawalt poimts out the close relationship between this argument and the argument from truth, noting that "[a] hiberal deinocracy rests ultimately on the choices of its citizens. Free speech can contribute to the

315. The problem with this analysis is that it depends upon severing legislation from the popular will; it abjures even a mildly strong notion of representative democracy. For if the people whose interests are supposed to be ennbodied in legislation through deliberative politics actually hold the views that Michelman envisions as embodied in an antipornography law, then there presumably would be no demand in the market, or at least very himited dennand, for pornography in the first place. People would forgo its purchase in pursuit of the greater good of participatory equality. And needless to say they would not silence women through inattention or the creation of a hostile environment. Yet there is, according to the argument, a very strong demand for pornography. In light of this demand, it is difficult to see how market-regulating legislation could be anything but the product of an interest group's efficient lobbying rather than deliberative politics. Professor Michelman's vision reduces to the proposition that sometimes the legislature is a better judge of the people's true interests than they are, and when that is the case there is no rcason for the eourts to be inore suspicious of state rather than private action. But this analysis begs precisely the question it should answer. If we are to ignore expressed preferences (expressed through the purchase of pornography, and so on) as the criterion of judging the true interests of the people, what shall wc use?

There are more pedestrian reasons to reject this thesis. The government is the only entity that can legally arrest you and throw you in jail for your speech, and various governmental bodies in this country have done so on more than one occasion. We submit this is sufficient rcason to be especially distrustful of governmental regulation. The case reporters are filled with cases in which individuals endured social condenmation, ridicule, and obloquy without being silenced. See, e.g., Cantwell v. Connecticut, 310 U.S. 296, 301-03 (1940) (Jehovah's Witness proselytizing in neighborhood coinposed of over 90\% Roinan Catholics); Christian Knights of the Ku Klux Klan Invisible Empire, Inc. v. District of Colunbia, 919 F.2d 148, 151 (D.C. Cir. 1990) (Randolph, J., concurring) (whitc supremacist groups sought to march down Constitution Avenue, in Washington D.C., just over a month after a mob prevented them from marching). As an historical matter, speakers have withstood such assaults from private parties and continued advocating their views; the saine cannot be said of the effects of miprisoninent.

68. Schauer, supra note 61, at 2 . This view, of course, does not resolve directly the problem of articulating criteria for identifying normative truth. All it does is to prevent one actor-the government-from deciding what is true and from imposing that decision through a specific means-restrictions upon speech. Given the relationship between speech and truth, this means that the governinent inay decide what is true for the purpose of crafting policy, but may not decide what the citizenry is allowed to believe is true. 
possibility that they, and their representatives, can grasp truths that are significant for political life . . ."69 This argument has special force because, as Robert Bork has put it, "the entire structure of the Constitution creates a representative democracy, a form of government that would be meaningless without freedom to discuss the government and its pohicies." 70

Current first amendment doctrime views speech relating to democratic self-governance as being at the "core" rather than the "periphery" of first amendment values. ${ }^{71}$ Thus, the Court views regulations of such speech with the greatest skepticism. ${ }^{72}$ Any regulation of offensive speech that touches upon issues relating to democratic self-governance will need to overcome the combined force of the general argument from truth and the enshrinement in our democratic structure of the values underlying that argument.

One element of the argument from democracy deserves special attention here: Without substantial refinement, the argument's premise proves too much. The argument views the people as sovereign, and it is their sovereignty which entitles them to all the information they need to make choices about what policy they desire. If the people are sovereign in that sense, however, we are confronted with a paradox: The first amendment exists precisely to deny a majority of the people the right to exercise their sovereign power to restrict speech. We may, perhaps, escape this paradox by conceiving of a form of democracy that does not rely solely upon majoritarian principles, a form of democracy which is in fact represented quite well by the Constitution. The problem is that recognizing that we have a republican forin of government tells us little, if anything, about how much we should protect speech.

Professor Schauer suggests that we may resolve the question by relying upon notions of equality and equal participation in government. As he puts it, "Equal participation by all people in the process of government is even more fundamental to the ideal of self-government than is the idea of majority power. . . If everyone is to participate equally, then everyone must have the information necessary to make that participation meaningful."73 In addition to providing a justification for maintaining a free flow of imforination, the argument from democracy suggests that "the minority's right to object, to attempt to influence the majority, to have some say $i m$ the formulation of final pohicy, provides the moral basis

69. Greenawalt, supra note 46 , at 145 .

70. Bork, Neutral Principles and Some First Amendment Problems, 47 IND. L.J. 1, 23 (1971).

71. See, e.g., Connick v. Myers, 461 U.S. 138, 145 (1983).

72. See, e.g., Texas v. Johnson, 491 U.S. 397, 410-11 (1989).

73. F. SCHAUER, supra note 59 , at 41 . 
for binding everyone to the rule ultimately adopted."74 With this understanding, we may say that decisions a inajority imposes upon a minority are illegitimate (because undeinocratic) to the extent the relevant minority did not have a fair opportunity to be heard on the issue.

We inust pause to note that we here speak of political minorities, which may or inay not correlate with any given social minority, such as homosexuals or African Americans. ${ }^{75}$ As these groups do not necessarily overlap, the claim that freedoin of speech legitimates to soine extent the imposition of political majority decisions upon a political minority might not apply witl equal force to majority inipositions upon social minorities. In the debate over regulations of offensive speecl some have argued that freedom of speech may in fact inake such imposition illegitimate. Strong claims have been raised that racist and other offensive speech effectively denies social minorities the opportunity fully to participate in the marketplace of ideas, and therefore of the opportunity to be heard on issues affecting their hives. If that claim is true, one may make a strong argument that racist speech is inimical to deniocracy because it undermines the ability of minority groups to participate in collective decisionmaking and therefore undermines the moral basis upon which any given majority may seek to curb a (political) minority to its will. ${ }^{76}$ The use of epithets in a debate on a political issue, for example, may effectively deter a person publicly fron expressing her view on the issue.

Social minorities therefore could beconie permanent political minorities in that they would be silenced on all issues of concern to thein, and thus always improperly subject to inajoritarian preferences. Even if the majority's preference coincided with that of a given social ininority group we would not say that the preference was denocratically constituted, even though its enforcement would not contravene the will of the social minority group. Members of social minority groups would be rendered vassals in a "beniguly" despotic state. The beniguity of a despot is, however, an iffy thing. Such a state of affairs would violate the equality necessary to maintain a substantively deniocratic governinent. This arguinent, however, tells us only that the nuajority may not inpair the ability of social minorities to participate in the political process. It does

74. Id. at 42 .

75. While it is perhaps fairly obvious, it bears stressing that social minorities do not have unique or even unitary views on all issues. There is no reason to believe, for example, that there is a unique homosexual view of the legitimacy of taxing corporations upon the distribution of appreciated property. Economic differences may be relevant, but there is no reason to believe that differences in sexual preference make a difference to a person's view on such matters. An individual's membership in a social minority group simpliciter therefore tells us nothing about whether that individual is part of a political minority on any given issue.

76. Post, Racist Speech, Democracy, and the First Amendment, 32 WM. \& MARY L. Rev. 291, 336 (1991). 
not tell us whether the majority must take affirmative steps to facilitate the political activity of social minorities so that their activity does not fall below some threshold at which the majority loses its claim to democratic legitimacy. Nor does it tell us whether restrictions on offensive speecl are necessary to allow for effective participation, or what kind of restrictions to adopt should we choose to do so. We leave the answers to these questions until later. ${ }^{77}$

\section{Free Speech and Tolerance}

The third consequentialist justification relevant to university restrictions of offensive speech is the argument that freedom of speech is crucial to engendering social tolerance. Dean Bollinger has made this argument the centerpiece of his first amendment theory. ${ }^{78}$ As Professor Greenawalt describes this view, its "basic idea is that if we are forced to acknowledge the right of detested groups to speak, we are taught the lesson that we should be tolerant of the opimions and behavior of those who are not like us."79 Although Dean Bollinger contends that tolerance is the core value underlying the first amendment, it is not clear why this should be. For present purposes, we may simply note that the relationship between speech and tolerance is important in considering regulations of offensive speech.

Three points regarding the scope of the tolerance rationale are important here. First, the communicative activity covered by the rationale is largely coterminous with the communicative activity covered by the inarketplace rationale. There is no reason to include false statenients of fact (unless we seek to become niore tolerant of falsity), and perhaps soine reason to exclude true statements of fact. Second, the rationalelike the argument from deniocratic self-governance-proves too much. The logic of tolerance could extend to all speech to which one might take exception, sucli as obscenity, vulgar personal attacks, and the like-areas of speech heretofore considered to have been outside tlie free speech principle. Such speech may deserve first amendment protection under the tolerance rationale, but we nust first identify the conditions in which such speech engenders tolerance, and then protect only speech that meets those conditions.

Finally, the rationale presents the risk that we will become too tolerant, that we will accept imjustice passively and abandon useful standards of behavior in favor of cultural nihilisn1. This arguinent is, of course, the quintessential appeal to the shppery slope and is subject to the weak-

77. See infra text accompanying notes 261-70.

78. See L. Bollinger, The Tolerant Society (1986).

79. Greenawalt, supra note 46 , at 146-47. 
nesses of all such argnments. ${ }^{80}$ Nevertheless, we should be cognizant of this risk, especially where we decide to protect speech that causes pain to those who hear it.

\section{B. Nonconsequentialist Reasons for Protecting Speech}

Nonconsequentiahist rationales for protecting speech necessarily view speech as good per se, though in application these rationales generally take the form of a consequentialist argument confined to the individual speaker. Thus, we may classify as nonconsequentialist those arguments that ground first amendment protection in "self-realization" and similarly hyphenated variants. Professor Redish has been the inost persistent advocate of nonconsequentialist reasoning. Under his theory, "the constitutional gnarantee of free speech ultimately serves only one true value . . . individual self-realization." "81 For Redish, the term is "chosen largely because of its ambiguity: it can be interpreted to refer either to development of the individual's powers and abilities ... or to the individual's control of his or her own destiny through making lifeaffecting decisions." 82 Professor Redish believes that all consequentialist justifications for free speech "are in reahty subvalues of selfrealization." 83

Not surprisingly, Professor Redish rejects the view that it is because speech is in some way different from other human activity that it warrants heightened protection from legislative restrictions. Yet if speech were not in some way different from other human endeavors there would be no reason to view speech regulations any differently than regulations governing the formation of contracts or the maximum highway speed. Redish views argnments attributing soine uniqueness to speech as yieldmg a "null set" of protected speech; ${ }^{84}$ he apparently rejects the view of the first amendment as a negative restriction on governinental authority and instead views it as a positive grant, for speech, of imınunity froin governinental restriction. The result of this rejection is predictable. Because Redish's broad self-realization rationale covers almost every activity, it offers hittle normative gnidance in determining when and what speech to protect.

An example may help demonstrate the point. Redish argues that if his theory were adopted, the two-level theory of speech first articulated

80. See generally Schauer, Slippery Slopes, 99 HARV. L. REv. 361 (1985) (describing conditions necessary for proper use of the argument).

81. Redish, The Value of Free Speech, 130 U. PA. L. Rev. 591,593 (1982).

82. Id.

83. Id. at 594.

84. See Commentary, 78 Nw. U.L. REv. 1307, 1307 (1983) (transcript of colloquy among several professors, including Redish and Schauer). But see Bork, supra note 70, at 23 ("there is something special about speech"). 
in Chaplinsky ${ }^{85}$ would be discarded ${ }^{86} \mathrm{He}$ also explains that under his theory two consenting adults could engage in a conversation consisting of a mere string of obscenities with full first amendment protection. ${ }^{87}$ Redish also inaintains, however, that speech posing a real threat of breaching the peace niay be regulated. ${ }^{88}$ This conclusion, however, cannot be derived from his premises. Departing from Redish's hypothetical, if we make the not unreasonable assumption that even speakers inciting to riot or screaming vile invective an inch from a histener's face are self-realizing in the Redishian sense, we must either protect the speech on that ground or abandon the notion that self-realization, simpliciter, is a sufficient justification for protecting speech.

The fighting words example points up a similar problenı with nonconsequentialist justifications such as self-realization. Speech has effects on all who hear it. Listeners are affected just as are speakers. The nonconsequentialist justifications, which tend to constitute largely undifferentiated arguments for liberty or freedom, do not take note of such effects. Thus, in the case of the speaker screaming invective in his listener's face, we inust acknowledge that while the speaker is "selfrealizing," the listener is almost certainly not. The appeal to self-realization-1neaning in this case the exercise of freedom-tells us nothing about low to resolve such a situation: do we prefer the claim of freedom to hurl invective or the claim of freedom from being the object of such invective, and upon what grounds do we justify our preference? The conflicting versions of freedon that he hidden in such justifications make their application questionable, especially in discussing regulations of offensive speecl, which are troublesome largely because they embody precisely that conflict.

\section{III}

\section{The VALIDITY OF UNIVERSITY REgULATIONS OF OFFENSIVE SPEECH}

We don't put as many restrictions on freedom of speech as we should. ${ }^{89}$ - Canetta Ivy

In each case ... perfectly bright, sophisticated people will come around saying, "This speech causes harm to me or someone that I value, and we

85. Chaplinsky v. New Hampshire, 315 U.S. 568 (1942); see infra text accompanying notes 98 106 (discussing the two-level speech doctrine).

86. Redish, supra note 81 , at 625 .

87. Id. at 627-28.

88. Id. at 626.

89. Campus Battle, supra note 19, at A20, col. 1. Ms. Ivy was a member of the three-member Council of Presidents that oversees Stanford University student government at the time she made this statement. Id. 
ought to suppress it."90

-Gerald Gunther

At least since Cohen wore his jacket to the courthouse, ${ }^{91}$ the first amendment has embodied one of the more widely accepted libertarian notions: that government inay not "1naintain what [it] regard[s] as a suitable level of discourse within the body politic."92 Although colleges and unversities generally accept this proposition, they have difficulty dealing with speech when the content inoves from a topic such as the draft to a social group. As noted above, ${ }^{93}$ universities have adopted three general approaches to regulating offensive speech on campus: regulations designed to prevent violence, regulations desigued to prevent offense to listeners, and regulations designed to protect certain groups from stigma. This Section examines each approach in turn.

\section{A. Regulations Designed to Prevent Violence}

Reasoning that "words can be used in such a way that they no longer express an idea, but rather are used to injure and intimidate, thus undermining the ability of individuals to participate in the University community,"94 the University of California has adopted a regulation prohibiting the use of "fighting words" on cainpus. The regulation defines fighting words as "those personally abusive epithets which, when directly addressed to any ordinary person are, in the context used and as a niatter of common knowledge, inherently likely to provoke a violent reaction whether or not they actually do so."95 Fighting words "include, but are not limited to, those ternis widely recognized to be derogatory references to race, ethiricity, religion, sex, sexual orientation, disability, and other personal characteristics."96 The regulation is expressly derived from Chaplinsky, ${ }^{97}$ and must be viewed im light of the history and theory of the fighting words doctrine.

\section{The Evolution of the Fighting Words Doctrine}

Chaplinsky was a Jehovah's Witness proselytizing before a

90. Id.

91. Cohen v. California, 403 U.S. 15 (1971). Cohen was convicted under a California statute prohibiting "maliciously and willfully disturb[ing] the peace ... by . . . offensive conduct" for wearing a jacket into the Los Angeles County Courthouse that bore the words "Fuck the Draft," capturing his feelings toward the Vietnam War. Id. at 16.

92. Id. at 23-24.

93. See supra notes 5-12.

94. Open Letter From David Gardner, President, University of California (Sept. 21, 1989).

95. U.C. Harassment Memorandum, supra note 6.

96. Id.

97. Office of the President, News and Public Affairs, University of California, Press Release, at 1 (Sept. 26, 1989) [heremafter U.C. Press Release]. 
Rochester, New Hampshire crowd unsympathetic to his message. ${ }^{98}$ Escorted towards the police station (apparently for his own protection), Chaplinsky confronted a city marshal with the accusation that the marslial was a "God damned racketeer" and that the city government was comprised of "Fascists or agents of Fascists." a statute narrowed by the New Hampshire Supreme Court to cover only "words likely to cause an average addressee to fight." 100 The state's rationale was clear: It punished Cliaplinsky's speech as a propliylactic exercise of its power to keep the peace.

The Supreme Court accepted this argument. ${ }^{101}$ The Court did not stop here, however. In a classic case of dicta giving rise to doctrine, the Court articulated a theory of the first amendment in which certain forms of speech simply are not to be treated as speech. According to the Court:

There are certain well-defined and narrowly limited classes of speech, the prevention and punishment of which have never been thought to raise any Constitutional problem. These imclude the lewd and obscene, the profane, the hibelous, and the insulting or "fighting" words-those which by their very utterance inflict imjury or tend to incite an immediate breach of the peace. ... [S]uch utterances are no essential part of any exposition of ideas, and are of such shight social value as a step to truth that any benefit that may be derived froin them is clearly outweighed by the social interest in order and morality. ${ }^{102}$

The Court's basis for excluding these categories was its implicit belief that achieving objective truth is the sole value underlying the first

98. The recitation of facts is taken from Gard, Fighting Words as Free Speech, 58 WASH. U.L.Q. 531, 532 (1980).

99. Id. The opinion in Chaplinsky does not directly indicate that the Court considered it important that the invective was delivered in an essentially face-to-face confrontation. The relevant New Hampshire statute, however, prohibited invective addressed "to any other person." Chaplinsky v. New Hampshire, 315 U.S. 568, 569 (1942). The New Hampshire Supreme Court considered this provision when interpreting the statute, concluding that "no words were forbidden except such as have a direct tendency to cause acts of violence by the person to whom, individually, the remark is addressed." State v. Chaplinsky, 91 N.H. 310, 313, 18 A.2d 754, 758 (1941) (emphasis added). The U.S. Supreme Court quoted this latter passage, but did not limit its holding accordingly. See Chaplinsky, 315 U.S. at 573. For this reason, Chaplinsky's famous quotation is largely dicta.

100. Chaplinsky, 91 N.H. at 320, 18 A.2d at 762 . The state court construction of the statute clarified not only the state interest to be vindicated, but also the very narrow range of prohibited speech. The purpose of the statute, as interpreted by the state court, was " "to preserve the public peace.' "Id. at 312, 18 A.2d at 758 (quoting State v. Brown, 68 N.H. 200, 201, 38 A. 731,732 (1895)). Given that objective, the court inade clear that what was "offensive" under the statute was not to be determined by the hearer's subjective response to the words. Id. at $320,18 \mathrm{~A} .2 \mathrm{~d}$ at 762 . Rather, the test was an objective one, and it could only be met by words that would be "ikely to cause an average addressee to fight," "plainly tending to excite the addressee to a breach of the peace," or "likely to cause violence." Id. at 320-21, 18 A.2d at 762. The court specifically stated that "[d]erisive and annoying" words were prohibited under the statute only if they were of such a nature as to ineet the incitement restriction as well. Id. at $320,18 \mathrm{~A} .2 \mathrm{~d}$ at 762 .

101. Chaplinsky, 315 U.S. at 573.

102. Id. at $571-72$ (footnotes omitted). 
amendment and that use of the marketplace is the sole method of achieving such truth. ${ }^{103}$ The Court fell prey to the simphistic, circular version of marketplace theory outlined above ${ }^{104}$ because it ignored the possibility that the Rochester police rather than what the Court itself perceived as Chaplinsky's cacophony posed the true impediment to truth.

Two elements of the Court's fighting words analysis are significant here. First, the Court equated offensive speech with speech that incites violence, referring to "insulting or 'fighting' words."105 Second, the Court divided speech into two classes, defining the unprotected class by reference to words that "by their very utterance inflict injury or tend to incite an immediate breach of the peace." 106 The Court offered no analysis to support its equation of speech that offends or injures with speech that incites violence. One is tempted simply to accept that offensive words will incite violence. Such an inference, however, is not only counterintuitive except at the margins, but also exacts a high price in unprotected speech. Subsequent cases, however, have made clear that the equation is not tenable as either a logical or constitutional inatter.

After Chaplinsky, the fighting words doctrine was largely dornant during the first amendment revolution of the 1960s, not surfacing again until Gooding v. Wilson. ${ }^{107}$ Wilson, along with soune others, was picketing agaimst the Vietnam War in front of an Army headquarters when he was arrested for obstructing access to the building. ${ }^{108}$ Upon his arrest, Wilson called one officer a "[w]hite son of a bitch," and threatened to choke the officer to death. ${ }^{109}$ Wilson advised a second officer that he would cut the officer "all to pieces."110 Wilson was prosecuted under a Georgia statute making it a misdemeanor to use "opprobrious words or abusive langnage, tending to cause a breach of the peace."111 Wilson's conviction was overturned on habeas corpus when the district court, with the Fifth Circuit affirming, held that the statute was void as vague on its face and overbroad. ${ }^{112}$ The Supreme Court affirned. ${ }^{113}$

From the manner in which the Court framed the issue it was clear that Chaplinsky had not fared well over time. As the Court saw it, the

103. Id. at 572 .

104. See supra text accompanying notes 49-68.

105. Chaplinsky, 315 U.S. at 572 (emphasis added).

106. Id. (emphasis added) (footnote omitted).

107. 405 U.S. 518 (1972).

108. Id. at $519 \mathrm{n} .1$.

109. Id. at $520 \mathrm{n} .1$.

110. Id.

111. Id. at 519 .

112. Wilson v. Gooding, 303 F. Supp. 952 (N.D. Ga. 1969), aff'd, 431 F.2d 855 (5th Cir. 1970), aff'd, 405 U.S. 518 (1972). The district court overturned Wilson's conviction only with respect to the speech statute. It let stand his conviction for assault and battery. Id.

113. Gooding v. Wilson, 405 U.S. 518, 520 (1972). 
statute was valid only if "it is not susceptible of application to speech, although vulgar or offensive, that is protected."114 The set of "vulgar and offensive" words that are not also "fighting" words is small indeed; the Court's question itself overruled Chaplinsky to the extent Chaplinsky equated speech that offends with speech that incites. Justice Brennan's opinion quickly resolved any uncertainty on this issue. The Court seized on the words "opprobrious" and "abusive" in the statute and noted that the dictionary defined them as "conveying or intended to convey disgrace" and "harsh insulting language," respectively. ${ }^{115}$ After a quick review of state court constructions, the Court found that the statute allowed convictions without proof of an "immediate violent response," and affirmed the lower courts. ${ }^{116}$

In the aftermath of Gooding and its string-cite coinpanion, Lewis v. New Orleans, ${ }^{117}$ it is clear that only the incitement rationale survives to justify fighting words restrictions. Lewis had been convicted under a statute that made it "unlawful and a breach of the peace for any person wantonly to curse or revile or to use obscene or opprobrious language toward or with reference to any member of the city police while in the actual performance of his duty."118 The Court, aganı without reference to the facts before it, found that the state court's construction had not adequately limited the statute, "opprobrious" having been disallowed in Gooding as embracing words that "do not "by their very utterance... . tend to incite an immediate breach of the peace." "119

114. Id. (citing Cohen v. California, 403 U.S. 15, 18-22 (1971), and Terminiello v. City of Chicago, 337 U.S. 1, $4-5$ (1949)).

115. Id. at 525 .

116. Id. at 528 .

117. 415 U.S. 130 (1974).

118. Id. at 132 .

119. Id. at 133 (quoting Gooding, 405 U.S. at 525 (itself quoting Chaplinsky v. New Hampshire, 315 U.S. 568, 572 (1942))). Justice Powell's concurrence in Lewis also makes clear that it is no longer possible to equate speech that offends with speech that incites. Because he read the relevant statute as creating a per se rule that the use of opprobrious language constituted fighting words, he found it to be facially overbroad. Id. at 134-35 (Powell, J., concurring). Justice Powell speculated that a police officer might well be expected to show greater restraint than an average citizen when confronted with fighting words. Id. at 135 (Powell, J., concurring). There are two relevant inplications to Justice Powell's position. The first is that the objective standard of what constitutes incitement is to be viewed with at least some degree of particularity, making it an objective-personin-the-addressee's-shoes test. Otherwise, that the reaction of a police officer might be different from that of a nonofficer would seem irrelevant to the analysis.

The second implication is that the maintenance of social order was still foremost in Justice Powell's mind. He does not suggest that a police officer would find the words less offensive, annoying, or painful than a civilian would. By focusing ouly on the decreased likelihood of violent action by the officer as a result of his superior training, Justice Powell makes clear that it is a social and not personal interest that Chaplinsky is properly read to protect. The Court approved Justice Powell's distinction between police officers and civihans in Houston v. Hill, 482 U.S. 451 (1987). In affirming the lower court's conclusion that a statute making it a crime to interrupt a police officer in the performance of his duty was overbroad, the Court referred to "the constitutional requirement 
Chaplinsky's at least partial demise must be understood in the context of the first amendment revolution of the 1960s. The Court's narrowing of the fighting words doctrine in Gooding mirrored its decisions in several other areas, most notably cases involving speech regulations designed to keep the peace and gnard public safety. ${ }^{120}$ Public safety cases differ from fightimg words cases in that the former involve speech that is widely distributed-for example speeches to a crowd or distribution of flyers - and they generally focus on the risk that a crowd will agree with the speecli and as a consequence act unlawfully. Fighting words cases, on the other hand, focus on face-to-face confrontations and the risk of violent disagreement. Not long before Gooding the Court severely restricted the scope of speech that could be regnlated under a public safety rationale by substantially tiglitening the clear and present danger test in Brandenburg v. Ohio. ${ }^{121}$ The Court's reasoning slieds light on Gooding's treatment of the Chaplinsky test.

The Court struck the statute at issue in Brandenburg because it punished both "mere abstract teaching" of the necessity of violence as well as the public mcitement of sucl action. ${ }^{122}$ This limited the range of regulable speech in the same way Gooding did-"mere abstract teaching" of doctrine presumably offensive to the government is the rough equivalent of speech that offends but does not incite. This can be seen most clearly by looking at Brandenburg in historical context. Brandenburg expressly overruled Whitney v. California, ${ }^{123}$ in which the Court had affirned the conviction under the Califorma Criminal Syndicalism Act of a member of the Socialist Party. Whitney's flaw was its adoption of reasoning first set forth in Gitlow v. New York, ${ }^{124}$ which explamed low broad regulations of speech could be rationalized under Justice Holmes' "clear and

that, in the face of verbal challenges to police action, officers ... inust respond with restraint." Id. at 471 .

120. The cases go back to the first major free speeeh opinion on record, Learned Hand's decision as a district judge in Masses Publishing Co. v. Patten, 244 F. 535 (S.D.N.Y.) (enjoining Postmaster from refusing to let anti-draft magazine be sent through the inail), rev'd, 246 F. 24 (2d Cir. 1917); see also Brandenburg v. Ohio, 395 U.S. 444 (1969) (overturning conviction under state statute that regulated speech advocating but not inciting lawless activity); Gitlow v. New York, 268 U.S. 652 (1925) (upholding conviction for publishing anarchist newspaper); Debs v. United States, 249 U.S. 211 (1919) (upholding conviction for public speech advocating socialism and condemning war effort); Schenck v. United States, 249 U.S. 47 (1919) (upholding conviction for circulation of flyer urging resistance to the draft).

121. 395 U.S. 444 (1969).

122. Id. at 448. At issue in Brandenburg was a speech at a Ku Klux Klan rally in which the speaker denigrated certain racial and ethnic groups and stated that "there might have to be some revengeance [sic] taken." Id. at 446. Yates v. United States, 354 U.S. 298 (1957), makes this distinction even more clearly. Justice Harlan noted that "[t]he distinction betwecn advocacy of abstract doctrine and advocacy directed at promoting unlawful action is one that has been consistently recognized in the opinions of this Court." Id. at 318.

123. 274 U.S. 357 (1927).

124. 268 U.S. 652 (1925). 
present danger" test. ${ }^{125}$ Justice Sanford argued in both Gitlow and Whitney that the legislature was perfectly capable of determining what types of speech constituted a clear and present danger, and that courts had no business second-guessing that judgment. As he put it,

[W] hen the legislative body has determined generally, in the constitutional exercise of its discretion, that utterances of a certain kind involve such danger of substantive evil that they inay be punished, the question whether any specific utterance coming within the prohibited class is likely, in and of itself, to bring about the substantive evil, is not open to consideration. ${ }^{26}$

For Justice Brandeis, this was far too coarse an approach to such a sensitive subject as free speech. He argued in concurrence that the courts inust determine whether a defendant's speech had in fact presented a clear and present danger of causing soine evil that the state properly could prevent. As he put it, "[t]he legislature inust obviously decide, in the first instance, whether a danger exists which calls for a particular protective measure. But where a statute is valid only in case certain circuinstances exist, the enactinent of the statute cannot establish the facts which are essential to its validity."127

Brandeis' point was that if the clear and present danger determination was to be divorced from the actual speech at issue in a given case, the first amendment would be a dead letter because the courts would always defer to the legislative determination. Brandeis demanded a judicial inquiry into exactly what the speech did. ${ }^{128}$ Brandenburg represents the triumph of Justice Brandeis' view and the rejection of judicial deference to legislative determinations of the lawfulness of broad classes of speech. The same principle apphies to governmental efforts to define any given class of speech as inherently "fighting words." In both public safety and fighting words cases, the Court now permits regulation only of speech that will cause an immediate, almost refiexive, unlawful response-as determined by courts examining the facts of specific cases.

The Court's rationale for narrowing the fighting words doctrine is not entirely clear from the cases. Nevertheless, the Court's preinise appears to be that if a listener's response is in any way deliberate, if it is

125. Schenck v. United States, 249 U.S. 47, 51 (1919)

126. Gitlow, 268 U.S. at 670; see also Whitney, 274 U.S. at 371:

By enacting the provisions of the Syndicalisn Act the State has declared, through its legislative body, that to knowingly be or becone a meniber of or assist in organizing an association to advocate, teach or aid and abet the commission of crimes or unlawful acts of force, violence or terrorisnı as a means of accomplishing industrial or political changes, involves such danger to the public peace and security of the State, that these acts should be penalized .... That determination must be given great weight.

127. Whitney, 274 U.S. at 374 (Brandeis, J., concurring).

128. Id. at 376 (Brandeis, J., concurring). Justice Brandeis would have had courts ask whether "inumediate serious violence was to be expected or was advocated, or that the past conduct furnished reason to believe that such advocacy was then contemplated." Id. 
the product of consideration of the ideas conveyed by the speech, then the offensive speech must be protected, even if the histener responded violently. ${ }^{129}$ This conclusion is bolstered by Yates' and Brandenburg 's references to the teaching of doctrine, protected because it involves ideas and results in rational deliberation, and explains Holmes' apt reference to unprotected speecli as that which "set[s] fire to reason." ment and fighting words doctrines therefore unay be seen as efforts to protect the individual's ability rationally to process speech. When statutes go beyond this core process-based protection to protect histeners froin the ideas commumicated, the rationale for the doctrines falls away because it is superfluous, and is replaced by the skepticisin of market place theory. Thus, a statute regulating offensive speech that involves the advocacy of an idea or doctrine and whicl is dissemmated in a inanner that allows the listener sufficient time and both physical and intellectual space to conteinplate the content of the speech would be overbroad under Gooding and Brandenburg.

So what does all this mean to the Umiversity of California? Because the regulation is expressly patterned after Chaplinsky, ${ }^{131}$ it at least theoretically runs the risk of overbreadth that arises from the equation of speech that offends with speech that incites. ${ }^{132}$ And indeed, the Umiversity of California regulation defines fighting words to include, apparently by irrebuttable presumption, "derogatory references to race, ethincity, religion, sex, sexual orientation, disability, and other personal characteristics." 133 This presuinption would seein to run afoul of at least

129. As one commentator puts it, "The primary requirement of the fighting words doctrine is hence designed to separate protected expressions of dislike or disrespect for another-to which the hearer's response, violent or otherwise, is essentially idcological-from those inherently provocative words that trigger responsive violence more the product of uncontrollable reflex than intellectual decision." Gard, supra note 98 , at 540 .

130. Gitlow v. New York, 268 U.S. 652, 673 (1925) (Holmes, J., dissenting). This interpretation of the cases helps explain Justice Brennan's reference in Gooding v. Wilson, 405 U.S. 518,526 (1972), to the hypothetical of one person directing insults at another across a river. The listener in the exainple presumably would have sufficient time to absorb and rationalize the offense of the remark and, through the exercise of her rational faculties, conclude that a violent response would be wrong. This notion of rational activity as a barrier to violent response also cxplains why it is unlikely that the fighting words exception would be applied to written speech-the mere act of reading the words would, presumably, sufficiently engage the reader's rational faculties to foreclose violent response as an option.

131. See U.C. Press Release, supra note 97.

132. See supra text accompanying note 105 .

133. U.C. Harassment Memorandum, supra note 6. This is not to say, as we have been interpreted as saying, that the regulation is violated solely by the use of presumptively "fighting" words. See Comment, Campus Anti-Slur Regulations: Speakers, Victims, and the First Amendment, 79 Calif. L. REv. 919, 949 n.192 (1991) (authored by Sean M. SeLegue). The regulation also requires the creation of a "hostile" environment. It of course takes more than a little imagination to sec how the use of "fighting" words could fail to be "hostile." More to the point, when a regulation has two conjunctive elements, the regulation as a whole is unconstitutional if either element is unconstitutional. 
Justice Powell's concurring opinion in Lewis, which argued that the statute involved was invalid for simply assuming that words that offend will also incite. ${ }^{134}$

Gooding and Lewis compel the conclusion that the Umiversity of California regulation is unconstitutional based upon the same impermissible equation of words. ${ }^{135}$ That result, however, is unfortunate from the perspective of first amendment theory. A shightly narrowed version of the regulation could pass constitutional muster if it regulated only the range of speech that not only offends but also imcites.

\section{Reconstructing Offensiveness: Fighting Words and the First Amendment Value of Offensive Speech}

To this poimt we have been very critical of the Chaplinsky Court. The Court's dicta, however, did contain at least an assertion that has retained a kernel of imtuitive truth for many who have studied the fighting words problein-that fighting words were "no essential part of any exposition of ideas" and were of only "shight social value as a step to truth."136 Although the Court offered no reasons to support this assertion, we beheve it had the right idea, though to apply it to the facts in Chaplinsky was plainly a mistake. The task is to articulate a theoretical justification for that assertion, and then to determine what types of regulation it will support.

The Court is firmly wedded to the notion of differential first amendment value for certain kinds of speech. As Justice Frankfurter put it, "[n]ot every type of speech occupies the same position on the scale of values. There is no substantial public interest in permitting certain kinds of utterances ...."137 Thus, for example, commercial speech occupies a "subordimate position in the scale of First Amendinent values."138 And, as Professor Schauer has noted, this process of "categorizing" speech is

134. Lewis v. City of New Orleans, 415 U.S. 130, 134-35 (1974) (Powell, J., concurring); see also supra note 119.

135. Stanford's current policy may suffer from the same deficiency. Paragraph 3 of the Fundamental Standard Interpretation defines harassment to include "vilification of students" on the basis of characteristics similar to those in the U.C. regulation. See Fundamental Standard Interpretation, supra note 8. Paragraph 4(c) of the Fundamental Standard Interpretation purports to limit the rule's applicability to cover only fighting words, defined as words that "by virtue of their form, are commonly understood to convey, in a direct and visceral way, hatred or contempt for human beings" possessing the protected characteristics at issue in the speech. Id.

136. Chaphinsky v. New Hampshire, 315 U.S. 568, 572 (1942). Having quoted these excerpts approvingly, we mnst quickly disavow as reckless and unprimcipled the Court's resort to balancing, using "order and morality" as counterweights. Id. As will be seen, if we must resort to balancing, those are not the proper counterweights.

137. Denmis v. United States, 341 U.S. 494, 544 (1951) (Frankfurter, J., concurring).

138. Ohralik v. Ohio State Bar Ass'n, 436 U.S. 447, 456 (1978). 
both dangerous and inevitable. ${ }^{139}$ The key to the analysis is to assess the speech that is asserted to be of lesser first amendinent value in light of the values einbodied in the first amendinent-the justifications for speech we examined above. This approach is coinpelled both by the Court's language-it says that it is working on a scale or hierarchy of values-and by the failure of either the text of the amendinent or the intent of the framers to provide inuch help. ${ }^{140}$ Working with the skeptical preinise of inarketplace theory, as outlined above, we need to restate the problein slightly. We inust ask whether the risk of state sanctions on speech is high or low for different kinds of speech, and what reasons support the choice in any given case.

With this framework, we may examine the University of California's regulation. As we saw earher, the regulation probably is invalid under current doctrine because its definition of fighting words includes speech that would offend but not incite a histener. Yet one tends to resist this conclusion because the category of speech causing the problein seeins both very narrow and unattractive. We have in mind here speech that for one reason or another will not provoke a violent response but regulaion of which does not seein even remotely tyrannical. The example of a prisoner locked in a cell (and therefore unable to respond to taunts), or of an infirm person unable to fight, will do to set the stage.

In such a case, where the hearer is incapable of an immediate response, Gooding suggests that even if the only speech involved were vile invective screamed into the recipient's face froin six inches away the speech would be protected because the state could not legitimately invoke the public safety rationale to regulate it. ${ }^{141}$ Yet this result seems wrong on both the nonconsequentialist account and the arguinent froin democracy. Nonconsequentialist justifications for protecting speech provide no reason to protect speech in this case. Although the speaker may be self-realizing, achieving harmomic convergence, or whatever, the "histener" is being deprived of her interest in precisely the saine values.

The arguinent froin deinocracy provides a inore coinplex question. One can imagine our hypothetical speaker mixing in pohtical commentary with invective. Additionally, either the speaker or the histener could gam soine forn of political insight from the encounter. At a minimum, we may assume that their views on restrictions of such speech will be greatly refined. Still, this argument is unsatisfying. To cast the hypothetical in narket terms, we do not have a consensual transaction. It is neither voluntary (because the histener wishes the speaker would stop),

139. Schauer, Categories and the First Amendment: $A$ Play in Three Acts, 34 VAND. L. Rev. 265, 282-96 (1981).

140. Bork, supra note 70, at 22.

141. Gooding v. Wilson, 405 U.S. 518, 526-27 (1972). 
nor mutual (because the listener is not given a cliance to respond or even rationally to process the speech). There is no reason to value sucli a "transaction" because it cannot lead to an increased understanding of an issue within the market. Neitlier logic nor precedent allows us to expand Gooding's incitement rationale, however, unless we can articulate a limiting principle that will safeguard the operation of the marketplace and ensure its vitality in the process of democratic self-governance.

We therefore must distimguish cases in which the argument from democracy provides sufficient reason to protect such speech from cases in which it does not, while still maintaining the integrity of the marketplace. We think this distinction can be given substance by drawing on an analogous distinction-the Court's emerging differentiation between public and private speecli. As the natural extension of its belief that "speecli on public issues occupies the "higliest rung of the lieirarchy [sic] of First Amendment values," "142 the Court has afforded the strongest first amendment protection to such speecli even when it is used in what looks like a private context. In Rankin v. McPherson, ${ }^{143}$ for exainple, the Court held that a worker could not be fired for commenting, after hearing of an unsuccessful attempt on President Reagan's life, that she hoped any future attempts would succeed. ${ }^{144}$ The worker's statement was made in a purely private conversation with a coworker, and was overheard by another coworker. ${ }^{145}$

The Court found the stateinent "was made in the course of a conversation addressing the policies of the President's administration," 146 and concluded that " $[t]$ he mappropriate or controversial character of a statement is irrelevant to the question whether it deals witli a matter of public concern."147 Rankin deinonstrates that the concept of public speecli has a very strong content base- the speech at issue was not distributed in anything reinotely reseinbling a public fashion. Moreover, one of Rankin's antecedents indicates that the topics included im "public" speecli include "any matter of political, social, or otlier concern to the community." 148 Nevertlieless, when speech falls outside the boundaries of public speech, the Court lias quickly cut off the protection of the first ainendinent. ${ }^{149}$

142. Connick v. Myers, 461 U.S. 138, 145 (1983) (quoting NAACP v. Claiborne Hardware Co., 458 U.S. 886, 913 (1982) (itself quoting Carey v. Brown, 447 U.S. 455, 467 (1980))).

143. 483 U.S. 378 (1987).

144. Id. at $381,384-89$.

145. Id. at 381 .

146. Id. at 386.

147. Id. at 387.

148. Connick v. Myers, 461 U.S. 138, 146 (1983).

149. See Dun \& Bradstreet, Inc. v. Greenmoss Builders, Inc., 472 U.S. 749, 761 (1985) (plurality opinion) (reducing constitutional value of credit reports). 
Thus, looking to the cases, we may say that the argument from democracy provides its strongest justification for protecting speech when the speech involved is public. This conclusion is somewhat tentative, however, because the Court has not fully addressed two critical questions raised by the argument: Why is the justification for protecting speech strongest with respect to public speech, and how do we know public speech when we see it? The answer to the first question appears fairly straightforward. Public issues are those about which people make decisions in acts that constitute self-governance-and people therefore must have access to all available information on such issues. At least from the perspective of the arguinent from democracy, this rationale provides a compelling reason to protect public speech, even in extreme situations. It should go without saying that the risks which inhere in giving the government power to restrict speech are highest when the speech is about the government.

Moreover, even assuming the primacy of self-governance values, we are left with our second problem: how do we know public speech when we see it? Unfortunately, the cases have not set forth predictable criteria for distmguishing public from private speech; Professor Post refers to the Court's efforts in this regard as "a dreadful mess."150 Nevertheless, the cases do provide a rough guide to the parameters of the distinction. The first, and arguably the inost important, characteristic distinguishing public froin private speech is content. This in turn is divided into two inquiries: whether the speech is normatively public-sonething about which citizens in a democracy should be concerned-and whether the speech is descriptively public-something about which citizens actually are concerned. ${ }^{151}$ The commentary in Rankin clearly falls within the former category, im contrast to the questionnaire at issue in Connick, which addressed primarily issues relevant to a single office, with only one passing reference to an issue of normative public concern. ${ }^{152}$ The Court appeared to assume that speech of descriptive public concern is public speech, even if it pertains to private individuals. ${ }^{153}$

The speech implicated by many university regulations is clearly analogous to private speech under either conception. The University of California regulation, for exainple, refers to "personally abusive epithets," which are deemed to include comments on several inmutable characteristics. ${ }^{154}$ Under no conception of democratic self-governance would we consider abusive epithets, directed solely toward an individual

150. Post, supra note 51, at 667.

151. See id. at 667-74.

152. Connick, 461 U.S. at 141-42.

153. See, e.g., Time, Inc. v. Hill, 385 U.S. 374 (1967) (play on matter of widespread pubic interest protected by the first amendment though based in part on private facts).

154. U.C. Harassment Memorandum, supra note 6. 
target, to be normatively significant. Nor would such epithets be likely to attract much descriptive interest, except perhaps where the target of the epithet was a public figure. ${ }^{155}$ Even in that case it likely would be the use of offensive speech that would be noteworthy, rather than the speech itself. Settimg public figure cases to one side, the content of personal invective is almost by definition private rather than public speech.

The second cliaracteristic frequently used to distinguish public from private speech is the inetlod by which the speecl is disseminated. Tlius, as Professor Post points out, we would view the parody of Reverend Falwell differently if it had been inailed to him, or read to him over the plione, rather than printed in a national magazine. ${ }^{156}$ Our assessinent of the metlod of dissemination depends in turn upon the inotive of the speaker-whetlier she intends her speech to be publicly, ratlier than inerely privately, considered. The intent requirement, however, is potentially problematic. It is at least plausible that speecli of objectively private content disseminated in an objectively private fashion inay be subjectively intended for public consumption. It is not too far-fetclied to imagine, for exannle, that Wilson's invective against his arresting officers was intended to be lieard by his fellow protestors and to strengthen their resolve in picketing, even if they could not in fact liear liim. ${ }^{157}$

The University of Califormia regulation does not address this possibility. Indeed, by reference to words that "as a inatter of cominon knowledge"158 incite violence, the regulation could be read, albeit uncliaritably, as imposing merely a negligence standard in such cases. Such a regulation is independently objectionable as overbroad, ${ }^{159}$ and causes needless confusion in cliaracterizing the regulation as covering public or private speecli. The analogy to the Court's public/private disthiction therefore cautions that the regulation should be interpreted to require a specific intent to offend tlie object of the speecli as a prerequisite to sanctions. ${ }^{160}$ Finally, the narrow category of speech we liave been discussing does not conflict with the skepticisnı of inarketplace theory. Because the regulation covers only speech that is extraordinarily offen-

155. See Post, supra note 51 , at 673 .

156. Id. at 675-76. As Rankin v. McPherson, 483 U.S. 378 (1987), indicates, however, speech on normatively public issues will be considered public discourse even where the speech takes place in a purely private setting.

157. See supra text accompanying notes 143-49 (discussing McPherson).

158. U.C. Harassinent Memoranduin, supra note 6.

159. The use of an intent standard to protect inarginal speech is an integral part of first amendment jurisprudence in the aftermath of New York Tines Co. v. Sullivan, 376 U.S. 254, 283 (1964). To the extent the U.C. regulation seeks to ban only true fighting words, it is crucial to narrow the scope of the regulation to words intended to offend.

160. Cf. Comment, supra note 133, at 951 . The regulation Mr. SeLegue proposes would include speech that the speaker "should reasonably know" would infiict harm as well as speech the speaker in fact knows would do so. 
sive to the histener, there is relatively hittle risk to the marketplace. Invective liurled at a "listener" from short range will most likely be experienced as an assault rather than as the expression of an idea for rational consideration. ${ }^{161}$ In sucli circumstances, there is not sufficient space-intellectual or otlierwise-to allow the histener rationally to process tlie speaker's argument, and there is therefore no possibility that the listener could engage in a consensual transaction with the speaker by inodifying her position to agree with tlie speaker's views. The regulation, modified by the suggestions we offer liere, would not seek to regulate ideas, but only to structure the inanner in whicli people speak to one anotler in order to facilitate the consensual excliange of ideas. Governinent regulation of sucli speech poses no greater threat than do regulations aimed at preventing transactions that are compelled by fraud or duress or are otherwise nonconsensual. ${ }^{162}$

Moreover, the analogy to the distimction between public and private speech allows us furtlier to refine the regulatory structure that emerges froin Gooding and Brandenburg. Those cases established a rule that allows punishment ouly where a violent response would be immediately fortlicoming, and forbids punishment of speech that in one way or anotlier gives the listener sufficient space to consider and reject the inessage and any unlawful alternatives. That distinction drives the proposed expansion of the figliting words category. The only difference here is that in cases like our hypotlietical, there would be, for one reason or anotlier, no risk of an unlawful listener response.

The relatively narrow formulation we suggest also is consistent with the doctrime of intentional infliction of enotional distress in tort law. Such tort doctrines already liave been applied to racist insults, and some cominentators liave argued for eitlier an expansion of the doctrine or the creation of a specific cause of action for outrageous racial insults. ${ }^{163}$ The problem witl sucli arguinents is the cominonly unstated preimise that the first amendment must accommmodate some sort of remedy for all harins caused by speecli. That premise was abandoned wlien it became clear that granting a reinedy for harms, and particularly dignitary harins, caused by speecli could render the first ainendment a dead letter. That is

161. In Professor Bickel's oft-recited words: "There is such a thing as verbal violence, a kind of cursing, assaultive speech that amounts to almost physical aggression, bullying that is no less punishing because it is simulated. ... This sort of speech constitutes an assault." A. BiCKEL, THE MORALITY OF CONSENT 72 (1975).

162. See infra text accompanying note 171 .

163. See generally, Delgado, Words that Wound, supra note 21; Richardson, Racism: A Tort of Outrage, 61 OR. L. REv. 267 (1982) (arguing that recognized actions in tort such as intentional infliction of einotional distress have great potential for offering compensation to victims of racial harassment, and perhaps even changing present societal racial beliefs), and cases cited therein. 
the point of Hustler Magazine, Inc. v. Falwell, ${ }^{164}$ in which the Court established that emotional distress claims are to be treated no differently than any other "dignitary tort." In Hustler, the Rev. Jerry Falwell sued Hustler magazine for, among other things, imtentional infliction of emotional distress based on an "ad parody" that Hustler published. ${ }^{165}$ The Court held that the actual malice doctrine of New York Times Co. v. Sullivan ${ }^{166}$ (which, after all, was created when a $\$ 500,000$ libel judgmient for admittedly false statements threatened to bankrupt certain leaders of the Soutliern Christian Leadership Conference) also applied to emotional distress actions brouglit by public figures. ${ }^{167}$ All concerned admitted that Falwell was a public figure, and this status was a premise of the disposition of the case. ${ }^{168}$ However, given that the narrow formulation offered above deals with purely private speech (that is, speecli privately addressed and not regarding matters of descriptive or normative public concern), it should not run afoul of Hustler.

Regulations such as the University of Califorina's are, of course, potentially unconstitutional at the margin. There is some risk of an erroneous governmental determination of truth, and some risk that a court will penalize what in a perfect world we would call public discourse. The point liere is that, with respect to the extremely narrow category of speecli we liave been discussing, those risks are minimal —as is the extent

164. 485 U.S. 46 (1988). The Court's holding in Hustler would seem to present problems for proposals that seek to build up from doctrines of tort law a broader regime of speech restrictions. See, e.g., Coininent, supra note 133, at $945-51$ (using tort law principles of susceptibility to justify restricting speech in a "civility zone" around potential victims). While Hustler itself concerned speech addressed to a public figure, the principles underlying the Court's public/private distinction, see supra notes 142-53 and accompanying text, make it clear that the rationale of Fustler will apply generally to pubiic speech, even if that ineans that tort law doctrines cannot be extended to justify regulation of offensive speech.

There is nothing novel in this couclusion, nor should the fact that the first amendment has not previously been required to displace such tort doctrines be read as a bar to its doing so now. $C f$. Ollman v. Evans, 750 F.2d 970, 995-96 (D.C. Cir. 1984) (concurring opinion of Bork, J.) (Judges should "adapt their doctrines" to any new causes of action that "become[ a threat to the central meaning of the first amendinent."). What Judge Bork perspicaciously points out in Ollman is that whether the framers, or traditional first amendment jurisprudence, had been concerned with the specific threat of the hibel action is not of great moment. Id. at 996.

What is important is that the Court be able "to see new threats to an established constitutional value," id., whether that threat is posed by a novel application of libel law, id., intentional infliction of einotional distress, Coinınent, supra note 133, at $945-51$, or hostile workplace analogies, id. at 952-55. The Court's holding in Hustler, premised as it is on New York Tiines v. Sulhivan, 376 U.S. 254 (1964), makes it clear that the Court is willing and able to resist such threats, and so to prevent the tail of tort law from wagging the constitutional dog.

165. Id. at $47-48$.

166. 376 U.S. 254 (1964).

167. Hustler, 485 U.S. at 56.

168. Id. at 57. The Court essentially decided the case when it decided that the New York Times standards applied, since the jury had already concluded that the parody could not reasonably be understood as conveying actual facts about Falwell. Id. 
to which such speech fosters the utilitarian values of the first amendment. Every regulation of speech will have some chilling effect, and it simply does not follow that all regulations are unconstitutional. ${ }^{169}$ It is therefore acceptable under the first amendment to regulate such speech on the basis of preserving the ability of potential histeners rationally to deliberate about the merits of ideas presented to them. ${ }^{170}$ Such a narrow regulation, however, differs greatly from more sweeping offense-based restrictions already adopted at various umiversities.

We must make one final poimt here. The modified regulation we describe is generic in the sense that it is designed to preserve the integrity of the process of dehiberatimg about ideas regardless of the speech at issue in any given case. It therefore resembles laws that render contracts obtained under duress voidable, im that the source of the duress (whether it be a gun, or blackmail, or anything else) is irrelevant. ${ }^{171}$ The law is justified simply by the preference for consensual over nonconsensual transactions. Similarly, any speech that, in context, abridges a listener's ability rationally to judge its inerits is not entitled to first amendment protection-even if the speech in a given case does not evince racism, or sexism, or a hatred of homosexuals.

This does not inean, however, that tle specific language used is irrelevant, nor that the use of racist speech (for example) could not be a significant factor in any given case. The degree to which speech used is offensive to the histener certainly does matter. Indeed, the notion that some speech is uniquely imtolerable provides the justification for the fighting words doctrine. Nevertheless, the use of racist or homophobic rhetoric alone may not constitutionally be taken as conclusive proof that the speech at issue in any given case is impermissible; such a position would embrace the equation condemned in Gooding, Lewis, and Hill. In any given case, all the factors necessary to determine whether the speech was used in such a way as to eliminate the possibility of rational deliberation inust be considered.

\section{B. Regulations Designed to Prevent Offense}

Even the most conservative legal scholars at the University of Wisconsm-Madison agreed that its proposed regulation of offensive speech was constitutional, ${ }^{172}$ and in July of 1989 the University adopted

169. Fort Wayne Books, Inc. v. Indiana, 489 U.S. 46, 60 (1989).

170. This resolution is quite obviously an example of balancing, a methodology traditionally disfavored in first amendment cases. This inethodology, however, reflects categorical balancing (determination of cases by reference to the categories of values inplicated) rather than ad hoc balancing (determiuation of cases by reference to the interests of the parties in each individual case). See K. Greenawalt, Speech, CRime, and the Uses of Language 221 (1989).

171. See RESTATEMENT (SECOND) of CONTRACTS $§ 175$ coininent a, $\$ 176$ (1981).

172. U.W. Racisin, supra note 9 . The press release did not identify the conservative scholars. 
a regulation based upon an amalgam of employment, first amendment, and civil rights cases. ${ }^{173}$ The Wisconsm chapter of the ACLU quickly announced that it would sue to invalidate the rule. ${ }^{174}$

The Wisconsin regulation begins by defining "intentional conduct" to encompass whit is commonly considered negligence-_"conduct which the student knew or reasonably should have known would result in conduct prohibited."175 The regulation goes on to prohibit expressive conduct that intentionally demeans "the race, sex, religion, color, creed, disability, sexual orientation, national origin, ancestry or age" of an individual and "create[s] an intimidating, hostile or demeaning environinent for education."176 The regulation, lowever, provides little guidance for determining when or how an environment becomes lostile, intimidating, or demeaning. In practice, though, it seems likely that this requirement can be met by a showing of conduct a student perceives to be demeaining. ${ }^{177}$

The Wisconsin regulation operates on the premise that speecl may be regulated if it is sufficiently offensive, without regard for its tendency to incite violence or to abridge the potential for rational deliberation. Similarly, Stanford Umiversity's current policy ${ }^{178}$ seeks to regulate more speech than is contemplated by the figliting words doctrine by removing the requirement that speech incite violence. The comments following the enacted proposal ${ }^{179}$ make clear that the policy expands the face-to-face requireinent to include a "small group" situation. The comments state that "more than one person can be imsulted face to face." 180 And, although expressly disclaiming any attempt to retain the group libel concept, the comments hearken back to the Beethoven poster incident, stat-

173. $I d$.

174. Id.

175. Board of Regents of the University of Wisconsin System, Proposed Order of the Board of Regents of the University of Wisconsin System Adopting, Amending and Renunbering Rules, at 2 (June 14, 1989).

176. Id. at 4.

177. Cf., e.g., Rogers v. EEOC, 454 F.2d 234, 238 (5th Cir. 1971) (arguing for a broad construction of the phrase "terms, conditions or privileges of employment" in the federal eniployment discrimination statute, and maintaining that "[o]ne can readily envision working environnients so heavily pollnted with discrimination as to destroy completely the eniotional and psychological stability of minority group workers"), cert. denied, 406 U.S. 957 (1972).

178. Fundamental Standard Interpretation, supra note 8, at 22.

179. The comnients serve as both a legislative history of sorts and as an interpretive guide. See T. Grey, Fundaniental Standard Interpretation: Free Expression and Discriminatory Harassnient 1 (Sept. 1989) (Grey's proposed interpretation of the Fundamental Standard subnitted to the Student Conduct Legislative Council). The Council issued the proposal (including the coninents) without change and as its own. See Fundaniental Standard Interpretation, supra note 8.

180. "Speech or other expression constitutes harassment by personal vilification if it . . is intended to insult or stigmatize ... a small number of individuals ...." Fundamental Standard Interpretation, supra note 8, I 4(a). "[I]t is evident that more than one person can be insulted face to face." Id. coninient 4. 
ing that "a poster placed in the coinmon area of a student residence might be found to be addressed to all the students living in that residence who possessed the characteristic vilified."181 The comments caution, however, that any determination would depend upon the intent of the student posting the picture. ${ }^{182}$ The exanple implies that the face-to-face requireinent has been considerably broadened.

Stanford's second deviation froin the tiglttly drawn fighting words doctrine is a soinewliat ambiguous attempt to reinove the "actual threat or likelihood of violent response" as "a necessary element for the application of the fighting words concept." ${ }^{183}$ The full ineaning of this provision is clarified by its author in a paper he has written on the subject. ${ }^{184}$ Professor Grey seeks to resurrect the previously inoribund first half of the Chaplinsky formulation, that is, words which "by their very utterance inflict injury." $185 \mathrm{He}$ analogizes this formulation to the inodern tort of intentional infliction of emotional distress, which requires that the harm-causing conduct inust be " 'beyond all possible bounds of decency,' and 'regarded as atrocious and utterly intolerable in a civilized cominunity'-in sliort, 'outrageous.' "186 By tlius broadening and combining the two standards, Professor Grey seeks to avoid what he terins the "purely predictive analysis" required by the traditional fighting words test. ${ }^{187}$

We want to use these regulations to examine the constitutionality of purely offense-based restrictions. Having discussed that topic with respect to purely private speech, ${ }^{188}$ we will here focus on the rationale as it applies to public speecll-roughly defined for present purposes as speecl on topics of norinative public interest or speech that the speaker intends to be heard by a group rather than merely by the immediate object of the speecli. Regulations based upon the offensive nature of speech provide a unique opportunity to examine a rationale that has been advanced forcefully to justify cainpus restrictions upon offensive speecl1-communitarian theory. Botli the Wisconsin and Stanford regulations partake of this rationale inplicitly and explicitly, and their validity rests in large part upon its validity.

181. Id.

182. Id.

183. Id.

184. T. Grey, supra note 8.

185. Id. at 17 (citing Chaplinsky v. New Hampshire, 315 U.S. 568, 572 (1942)).

186. Id. at 18 (citing RestatemeNT (SECOND) OF TORTS $\S 46$ comment d (1965)). For the groundbreaking effort at incorporating racial epithets into tort law, see Delgado, Words that Wound, supra note 21.

187. T. Grey, supra note 8, at 17. As we argued in the preceding Section, this attempt to avoid the "predictive" nature of the fighting words doctrine is nothing more than an alternative rhetorical justification for the equation of speech that offends with speech that incites. The regulation is therefore invalid in light of Gooding and its progeny. See supra text accompanying notes 107-16.

188. See supra notes $154-57$ and accompanying text. 


\section{Communitarian Theory and Offensive Speech}

On the communitarian view, persons derive a noral identity and the ability to make "determinate choices about how to hive" only as menibers of particular groups or communities. ${ }^{189}$ It is common for a canipus to define itself as a "community."190 Given this fact, and given Aristotle's statement that "every community is established with a view to sone good," 191 one can see how a particular community (the university), with a particular view of the good (enhancing racial or sexual equality), could seek affirmatively to proniote the good by limiting speech that contradicts the good. Many proponents of campus regulations of offensive speech express such a view of the good. Professor Matsuda, for example, argues that universities present a special case justifying the regulation of speech at least in part because umiversity students present a particularly vuhierable class of potential victims of racist speech. ${ }^{192}$ She stresses that they are away from home for the first time and "dependent on the university for community." 193 She contends that these university "comnuunities" "exist and stand for" the goals of "inclusion, education, development of knowledge, and ethics."194

The existence of a community, however, does not in and of itself tell us anything about the desirability of regulating speech. It is important to note Professor Post's argunient that there nust be some point at which coinmunity norms (embodied in prohibitions in or regulations of speech) must be suspended so that members of the comnunity niay critically

189. Note, Communitarian Defense, supra note 21, at 689 (citations omitted); see also Smolla, supra note 21, at 3 (explaining that one impulse "[vying] energetically for control of our legal culture" is that "nian is a creature of the state" and "[o]nly through conımunal hiving and through the state nay men achieve virtue").

190. See, eg., Office of the Dean, Harvard College, Procedures for Dealing with Concerns of Racial Harassment (Feb. 1988) ("[r]acial harassment is unacceptable in the Harvard community"); Loyola University, Racism and Bigotry ("Loyola University is committed to being a racially, ethnically and culturally diverse community"); Commonwcalth of Massachusetts Board of Regents of Higher Education, Policy Against Racism and Guidehines for Campus Policies Against Racisn 2 (June 13,1989 ) ("[t]he policy reaffirms ... the pre-eminence of mdividual human dignity as [a] precondition[] to the aclievement of an academic community"); Marquette University, Racial Abuse and Harassnent Policy (May 5, 1989) ("the University is conmuitted to maintaining an environment in which the dignity and wortl of eacll nember of its community is respected"); J.T. Casteen III, University of Conneeticut, The President's Policy on Harassment (Feb. 10, 1988) ("[t]he University of Conneeticut reaffirms that it does not tolerate liarassment direeted toward any person or group within its community"); West Virginia Wesleyan College, Social Responsibility Statenuent ("[a]1] individuals ... of the West Virginia Wesleyan College community are expected to speak and act witl respect for the hunıan dignity of others") (enıphasis added in all cases).

191. ARistotle, The Politics, bk. I, ch. 1, reprinted in G. Christie, Jurisprudence: Text and Readings on the Philosophy of Law 13 (1973).

192. Matsuda, supra note 21 , at 2370-73.

193. Id. at 2370-71 (enuphasis added).

194. Id. at 2371. 
analyze views not instantiated in the comınunity's norms. ${ }^{195}$ With respect to content-based restrictions on speech, the members of a cominunity therefore must at some point allow for speech that violates community norms. The alternative is to embrace a static community in which ideas and norms evolve internally, if at all, and in which the commumity abjures the possibility that any views outside its norms could possibly have merit.

Even assuming, however, that community norms are to apply in any given case, there are several nore pressing problems with the comniunitarian view. First, even assuming that equality is a necessary ideal of any community, ${ }^{196}$ the communitarian vision (at least as presented by the authors cited here) offers no objective rationale for resolving conflicts between the ideal of equahity and any other ideal a conımunity might hold. The doctrime rehes upon the normative power of whatever happens to be the actual state of affairs in any given community. And, while niost communitarian commentators seem to view the first ainendment as a procedural device, it too arguably expresses substantive values (such as tolerance) and contributes directly to both the individual and social (cominunity) good. ${ }^{197}$ To the extent, then, that the first ainendinent expresses an ideal value of the university coniniunity, the tension between free speech and freedom from racial harm renains unresolved. 198

Worse, if we accept the cominunitarian rationale for limiting racist speech, there almost certainly will be strong negative consequences for the first amendment. ${ }^{199}$ The primary problem with regulations based upon the offensiveness of speech, whether justified by comniunitarianism or some other theory, is to define what types of offense will suffice to trigger the regulation. Communitarian theory holds that "certain affiliations and viewpoints are central to a person's moral identity . . . because they make reflective, deliberative choice possible."200 Under the comniu-

195. Post, supra note 51, at 638-39.

196. History provides many examples of polities one would be tempted to call communities, which seemingly had no commitment whatsoever to the ideal of equality: the Athens of Aristotle's day, for example, which made liberal-or perhaps communitarian-use of slaves. The key question for any community is who will be viewed as a member, and thus an equal.

197. See, e.g., F. SCHAUER, supra note 59, at 35 ("The argument from democracy views freedom of speech as a necessary component of a society premised on the assumption that the population at large is sovereign."), 49 ("Aristotelian coneeptions of happiness present a stronger argument for freedom of speech as an intrinsic good.").

198. This is not necessarily to say that first amendment values are not part of a community that suppresses some speech, but merely that those values are trumped by other, stronger values which in this context may be taken to define the community.

199. See generally Redish \& Lippman, Freedom of Expression and the Civic Republican Revival in Constitutional Theory: The Ominous Implications, 79 CALIF. L. REV. 267 (1991) (arguing that adopting a civic republican view of law would have extremely negative effects on free expression).

200. Note, Communitarian Defense, supra note 21, at 689. 
nitarian view, the limits on speech therefore would be confined to offenses against such "constitutive" elements of community members. Even such a seemingly narrow standard, however, may permit the suppression of an extraordinary amount of speech. ${ }^{201}$

For example, the Wisconsin regulation addresses this problem simply by setting forth hists of characteristics that may not be made the subject of derogatory comment-race, sex, religion, sexual orientation, and so on. ${ }^{202}$ Assuming for the moment that those cliaracteristics are proper triggers for the regulation - which is to say that they fall within the realm of commumitarian "constitutive elements"-we must ask what criteria were employed to select those characteristics, whether the criteria compel the protection of other cliaracteristics as well, and whether the criteria are appropriate in the first place. To do so, we may compare the preferred characteristics to others which all would agree are not proper triggers for the suppression of speech: ${ }^{203}$ a student's stance on abortion or affirmative action, for example. ${ }^{204}$ What distinguishes the preferred from the unpreferred categories? One is at first tempted to say that the proper triggers (constitutive elements) reflect immutable characteristics while the improper triggers (things we merely feel strongly about) do not. But that is not correct-at least with respect to religion. Moreover, the immutable cliaracteristics theory is vastly underinclusive witl respect to potentially offensive speech, unless one is willing to assume that every human cliaracteristic not listed in the regulations is also not immutable. Even apart from the problein of underinclusiveness, however, one is entitled to ask why immutable cliaracteristics are entitled to such special

201. The author of Note, $i d$., argues that communitarian theory "does not necessarily support extension of group libel provisions beyond religious and racial vilification." Id. at 693. The broad range of characteristics listed in most of the campus regulations discussed in this Comment shows, however, that different communities define "constitutive" differently.

202. See WIS. Admin. Code § UWS 17.06(2)(a) (Aug. 1989) (University of Wisconsin rule allowing discipline of students for expressive behavior or physical conduct meant to "demean the race, sex, religion, color, creed, disability, sexual orientation, national origin, ancestry or age" of an individual). The regulation is currently being challenged as a violation of the first amendment, in UWM Post, Inc. v. Board of the University of Wisconsin Systen, No. 90-C-0328 (E.D. Wis. filed Mar. 29, 1990).

203. By this we do not intend an appeal to the shared values of the conımunity of readers. Rather, we wish simply to assert that under the theories outlined above, the following examples constitute paradigmatic cases for invoking the protection of the first amendnient.

204. We include the latter topic to show that it is possible to engage in a face-to-face interracial dialogue that, no matter how offensive, would not be regulable under marketplace theory. Thus, we assume that a conversation in which a student tells an African American student that the African American is the beneficiary of affirmative action, describes affirmative action as an ill-conceived policy based upon liberal guilt, and states that the African American was therefore improperly adnitted to school is clearly protected speech. The result should remam the same even if the incident involved the use of a racial slur. See T. Grey, supra note 8, at 21 (explaining that while racial hatred can be expressed without the use of racial slurs, the Stanford provision prohibits only abusive speech containing such slurs). 
treatinent. That an individual is unable to change a given characteristic does not compel the conclusion that derogatory references to that characteristic are necessarily dehumanizing, and it is a further jump to conclude that such references are invariably sufficiently dehumanizing to warrant the suppression of speech.

Conversely, we are all familiar with fights started over references to such consummately mutable characteristics as ideology. One could, for example, argue that the sometimes (literally) incendiary activities of disputants over the right to have an abortion are at bottom ideological disputes over the proper role of women in society. ${ }^{205}$ Indeed, in the debate over campus "diversity" (of which the debate over regulations of racist speech often seems only a part), it is not uncommon to see students take enormous offense, often to the point of either violence or tears, at vigorous attacks on their views. We may hazard a guess that such offense arises from a deeply felt behef in the fundamental correctness of the offended students' position as compared to the perceived bestial stupidity displayed by the other side. But regardless of the dynamic generating the offense, we find it difficult to conclude that derogatory remarks directed toward immutable characteristics are necessarily more offensive than derogatory remarks directed at changeable things like ideology. ${ }^{206}$

Bereft of immutability, however, the commumitarian view offers no other criterion for differentiating among the clamis of different communities to have their defining characteristics dressed up in constitutive garb and given the power to suppress speech. This shortcoming becoines even more pronounced as we move from considering purely local communities to broader commumities encompassing a wider variety of members. For example, while the Wisconsin regulation would not consider citizenship in this country constitutive, nationahism presents a strong problem for the communitarian view. The prevalence of the nation-state as the dominant form of social organization and governance in modernity ${ }^{207}$ has created what are in essence national communities. National communities are of necessity comprised of fewer common elements than, for example, a rural Georgia town. ${ }^{208}$ The sole and literally constitutive eleinent of such commumities is the identity of the individual as a member of the

205. See K. LuKer, Abortion ANd the Politics of Motherhood 158 (1984).

206. The history of the first amendment is in significant part a study in the perceived power of ideology to stir people to violence, either to carry forward an agenda or to respond to attaeks against one, and the efforts of the state to head off such violence. See supra notes 120-30 and accompanying text.

207. See, e.g., Will, Person of the Millennium, Wash. Post, Dec. 16, 1990, at K7 (arguing that the two great developments of this millennium are the nation-state and political freedom).

208. See generally Bowers v. Hardwick, 478 U.S. 186 (1986) (upholding constitutionality of antisodomy statute); Symposium: Law, Community, and Moral Reasoning, 77 CALIF. L. REv. 475 (1989). 
nation. The community therefore has a significant interest in defending against offense to that element, especially when one realizes that the community speaks (at least in this country) through the voice of the national government. This imphies, at a minimuin, that the flag burning cases ${ }^{209}$ were wrongly decided. ${ }^{210}$ The Justices agreed that the flag is the unique synibol of the national community. ${ }^{211}$ If an attack on equality (such as racist speech) is regulable for being an attack on a central value of the given community, then by the same reasoning, an attack on the syinbol of the community itself-or on any of its values-inust also be regulable. 212 The question then beconies how many other "attacks" on the "community itself" can we properly prohibit?

The failure of communitarian theory to provide criteria sufficient to differentiate among what are asserted to be constitutive characteristics reveals perhaps its most serious shortcoming. Communitarianism potentially justifies many legal systeins that are repugnant by any kind of norinative standard. Strongly stated, communitarian theory claims support froin the arguinent froin deinocracy, with its concern for equality, as an affirmative mandate for restrictions on speech: "The toleration of group vilification ... demes the targets of such expression equal meinbership in the pohtical community, because in denying recognition to sensibilities essential to their identities, toleration fails to respect their

209. Texas v. Johnson, 491 U.S. 391,410 (1989) (holding unconstitutional a statute passed by the Texas Legislature, which had the clear purpose of preserving the flag as a "symbol of national unity"); United States v. Eichman, 110 S. Ct. 2404, 2408 (1990) (striking down the Flag Protection Act of 1989 on first amendment grounds notwithstanding the government's contention that it had an interest in safeguarding the flag as "the unique and unalloyed symbol of the Nation").

210. Professor Smolla takes exception to the counter-example of flag burning, calling any proposed restriction "forced patriotism." Smolla, supra note 21 , at 41 . The presumed difference between forced patriotism and forced anything else that might serve as a constituent element of a community is not clear to us.

211. Johnson, 491 U.S. at 405 ("The very purpose of a national flag is to serve as a symbol of our country."), 421 (Kennedy, J., concurring) ("the flag is constant in expressing beliefs Americans share"), 422 (Rehnquist, C.J., dissenting) ("For more than 200 years, the American flag has oceupied a unique position as the symbol of our Nation .....").

212. That a symbol of a community might be afforded the same protection as a central value of a community is not unreasonable. To remain a community (or a nation), a group of people so constituted must have certain primary symbols that embody their shared values. See generally $2 \mathrm{~J}$. HABERMAS, ThE TheORY OF COMMUNiCATIVE ACTION 47-53 (T. McCarthy trans. 3d corr. ed. 1985). Habermas interprets Emile Durkheim to say that

[a]ll sacred objects-flags, emblems . . . have the same semantic core: . . . they are 'collective ideals that have fixed themselves on material objects'. . . . [1]t is only by expressing their feelings, by translating them into signs, by symbolizing them externally, that the individual consciousnesses, which are, by nature, closed to each other, can feel that they are communicating and are in unison.

Id. at 51 (quoting Durkheim, The Dualism of Human Nature and Its Social Conditions, in EssaYs oN Sociology, Philosophy, AND Aesthetics 335 (K. Wolff ed. 1965)). Thus a theory entailing the regulation of attacks on central commumity values (because such values are what makes the group a community) would seem also to entail the regulation of attacks upon the syinbols of such values. 
personhood."213 It is not entirely clear what a "political community" is, or what could be constitutive for such a community. Nevertheless, this is certainly a very powerful appeal, and it points up a potential conflict between the democratic self-governance and tolerance rationales for protecting speech. We inust therefore examine its premises carefully. When we do, it is apparent that from such seemmgly unassuming and benign premises soine extraordinarily totahtarian conclusions follow.

The most obvious objection to this theory is that it has no substantive content beyond the need to keep the group coherent. If we can prohibit racist speech to protect the personhood and equality of ininority groups, why can we not prohibit speech advocating affirmative action in a community coinposed of ardent segregationists? Unfortunately, the commumitarian response is not persuasive. That response maintains that only some group affiliations are important enough to warrant protection under the personhood rationale. Race, rehgion, "and perhaps a limited number of other" constitutive affiliations potentially justify restrictions upon offensive speech. ${ }^{214}$ We therefore find ourselves asking again what is so special about these groups? And once inore we find that immutability will not do, and there is no other criterion in sight. If we simply define a constitutive affiliation as one that is important to persons at level $X$, then we must grant such preferred status to all affiliations reaching or crossing that threshold. Given that "white flight" remains a persistent problein for our nation's schools, ${ }^{215}$ one may at least cast a skeptical eye on the clami that segregationist affiliations do not meet that threshold. The coinınumitarian response offers no way neutrally to prefer the claim of minority groups over the clain of segregationists, and inoral claims for coinmumitarian primciples ultimately degenerate into the subjective preference for the claims of iminority groups. ${ }^{216}$

The Uinversity of Missouri provided an interesting example of this problem when it denied recognition to a student group called Gay Lib. ${ }^{217}$ The campus justified its decision by pointing out that sodomy was a

213. Note, Communitarian Defense, supra note 21, at 691 .

214. Id. at 693 . The author states that family affiliations, sexual preference, gender, and ethnicity might also be constitutive. Id. at $693 \mathrm{n} .74$.

215. See Applebome, School Segregation More Than a Memory, San Francisco Chronicle, Apr. 22, 1991, at A4, col. 1, noting that this year in Summerton, S.C., site of one of the five lawsuits consolidated in Brown v. Board of Education, 347 U.S. 483 (1954), only 23 of the 1,274 public school students are white. Id. at 4, col. 4; see also Missouri v. Jenkins, $110 \mathrm{~S}$. Ct. 1651, 1667-68 (1990) (Kennedy, J., concurring) (detailing multi-hundred-million dollar plan the district court found was necessary to attract white students to public schools).

216. For critiques of communitarian thought along these lines, see Kahn, Community in Contemporary Constitutional Theory, 99 YALE L.J. 1, 80-81 (1989); Massaro, Equality and Freedom of Expression: The Hate Speech Dilemma, 32 WM. \& MARY L. REv. 211, 238 (1991).

217. Gay Lib v. University of Mo., 416 F. Supp. 1350 (W.D. Mo. 1976), rev'd. 558 F.2d 848 (8th Cir. 1977), cert. denied, 434 U.S. 1080 (1978). 
crime in Missouri. ${ }^{218}$ In reasoning that seems to foreshadow Professor Matsuda's argument that for a umversity to permit racist speech is to participate in discrimination, ${ }^{219}$ the university and the district court found that "[w]hen you institutionalize a cluster of behavior, you are giving it a thrust. You are bound to perpetuate it."220 Having accepted this premise, the campus found it clear that recognizmg Gay Lib would lead to violations of the criminal law, and so the campus considered itself justified in not recognizing the group. ${ }^{221}$ Gay Lib highlights a basic flaw in the communitarian viewpoint. The commumity's norms are the baselime from which similarity is ineasured, and inembers of a community do not view persons who violate those norms as similarly situated. Because equal protection is commonly considered to command only that similarly situated persons be treated similarly, ${ }^{222}$ the commumity can always justify its pumishment of lawbreakers as consistent with its notion of equality.

Gay $L i b$ demonstrates that persons who contradict the core values of the community (as embodied most clearly in its criminal laws) are not members in the full sense of the word. As a consequence, the community feels no need to treat them equally. The University of Missouri's premise also argues that because a community inust promote its vision of the good life for the benefit of its nembers, it is both permitted and obligated to exclude not only direct violations of that good, but also challenges to it, since such challenges are inherently likely to violate the good. The communitarian view thus leads to the elimmation of the "buffer zone" provided by the first amendment's stringent requirenents for incitementbased regulations. ${ }^{223}$ The communitarian attenipt to ground racist speech restrictions in the "inherent values" of the community is thus susceptible to criticisin for providing either not enough justification for

218. Id. at 1358.

219. Matsuda, supra note 21 , at 2378 ("To allow an organization known for violence, persecution, racial hatred, and commitment to racial supremacy to exist openly, and to provide . . access to . . . college campuses for such a group, means that the state is promoting racist speech.").

220. Gay Lib, 416 F. Supp. at 1368 (quoting testimony of Dr. Voth, a "highly qualified medical expert in the homosexual field"). The court adopted the statement as a finding of fact. Id. at 1369.

221. Id. at 1368-70. Neither the court nor the university appeared overly concerned that students might engage in prohibited sexual activity even without the university's approbation. One may expect that the university reduced violations of the law, if at all, by a very thin margin. Its stance was symbolic and was upheld as such by the court.

222. See Tussman \& tenBroek, The Equal Protection of the Laws, 37 CALif. L. REv. 341, 344 (1949) (explaining that classifications can be constitutional simce the Constitution does not require that different things be treated by the law as if they were identical).

223. As noted above, the circuit court reversed. Gay Lib, 558 F.2d 848 (8th Cir. 1977), cert. denied, 434 U.S. 1080 (1978). The issues presented in Gay Lib are unfortunately not unique. See, e.g., Gay \& Lesbian Students Ass'n v. Gohn, 850 F.2d 361 (8th Cir. 1988) (reversing district court decision upholding student senate's denial of funding to homosexual student group); Gay Student Servs. v. Texas A\&M Univ., 737 F.2d 1317 (5th Cir. 1984) (reversing district court decision upholding university's denial of recognition to homosexual student group), cert. denied and appeal dismissed, 471 U.S. 1001 (1985). 
regulating speech in soine circuinstances, or too strong a justification in too many others.

\section{The Source of the Offensiveness}

Let us assume for the moment that the speech we are talking about herein is deeply offensive to the people who are the objects of the insults. Let us also assume that such offense is so severe that it impairs both the self-realization of those persons and their ability effectively to participate in the political process. The question relevant to the first ainendinent is: What is the source of that offense? To reiterate, we are here talking about speech on normatively public topics or speech intended for a pubhic audience. Private offensive speech, as previously argued, inay be regulated where it abridges a histener's ability rationally to process the speech. ${ }^{224}$ We are here talking about speech that is disseminated in a coherent way and allows the histener sufficient intellectual and physical space to consider the speech. ${ }^{225}$ The point we shall attempt to make here is that the speech offends people (here, students on a campus) because of the ideas it conveys. We beheve that such feelings of repulsion cannot support a regulation of offensive speech without completely undermining the skeptical premises of marketplace theory.

This is a difficult proposition, so we allow ourselves the luxury of an easy first example. A speaker addressing a group of practicing homosexuals expounds the theory that homosexuality is both deviant and sinful. Such a speech may or may not violate the Wisconsin regulation, ${ }^{226}$ but we may assume that the immediate audience would be enormously offended. The important point is that in this hypothetical, the offense would arise from the audience's vehement disagreement with the speaker's ideas, and this would hold true for all encounters that offend the relevant histeners without hterally preventing them from processing the information. Thus, even where the same ideas were expounded by a speaker im a face-to-face argument with a member of the relevant group, the histener would be offended by the idea being championed. The context may change both the degree to which the argument becomes heated and the severity of the offense the histener feels. The listener may feel a

224. See supra notes 136-71 and accompanying text.

225. It is easy to make too much of this limitation. We consider it very narrow. A face-to-face confrontation, no matter how intense, is not within this limitation until some characteristic of the speech, such as its volume, renders a listener incapable of processing what was being said.

226. The argument that the speech would violate the regulation arises from the regulation's extraordinarily broad definition of intent as including conduct that a speaker "reasonably should have known would result in conduct prohibited." WIS. ADMIN. CODE \& UWS 17.02(11) (Aug. 1989). One may plausibly argue that our hypothetical speaker should have known his speech would encourage others to demean homosexuals (assuming the speech somehow were distributed beyond the immediate audience). 
sense of personal invasion that otherwise would be diffused by the greater spatial and intellectual distance of a formal speech. The source of the offense, however, remains the same. Doctrinally, the result would remain the same in a conversation in which those ideas were mixed with invective-as Hustler Magazine, Inc. v. Falwell demonstrates. ${ }^{27}$

Similarly, when a speaker hurls homophobic invective in conjunction with commentary on inatters of public interest or with the generic intent to address the public, the speech would be protected. The saine result should obtain even if tlie overwlielming inajority of tlie speecli was invective. Altliougli it is somewliat less clear in this case, the tlreory is that the generic intent (tliat is, the fact that the statement was addressed to a group) generates an intellectual buffer zone between tlie speaker and the potentially offended histeners, and thus preserves the ability of the individual to rationalize the speech. Even if tlie speech generates great offense and appears irrational, listeners experience (or should be expected to experience) such speech as part of the general public exposition of ideas-even if the idea is inerely tliat of a crude liatred of the relevant group. ${ }^{228}$ The source of the offense is the crude idea that emerges through tlie filter of public discourse. ${ }^{229}$ Thus, the speecli subject to the Wisconsin regulation is precisely the type of speech that is protected under Gooding and Brandenburg. ${ }^{230}$

The source of the offense caused by such discourse is the key to analyzing the validity of offense-based regulations. Where the idea the speaker expounds is tlie source of the offense, the skepticisin of marketplace theory teaclies that we inay not regulate the speech to protect listeners, no matter liow severe the offense they suffer. To liold otlierwise would allow the government to define as true an idea to wlich at least persons prosecuted under a given regulation likely do not subscribe (or to

227. 485 U.S. $46,56-57$ (1988) (denying relief to a public figure who had been brutally parodied in a national magazine on the ground that the parody was not done with "actual malice" and that, absent actual malice, the first amendment does not permit sanctions against speech merely because the ideas expressed are offensive).

228. Thus, this situation is similar in structure to the public incitement cases. To be regulated, the speech must be of a kind to incite immediate violence. Where there is an opportunity for reason to intervene, the speech may not be regulated. See, e.g., Brandenbnrg v. Ohio, 395 U.S. 444, 447 (1969) ("the constitutional guarantees of free speech and free press do not permit a State to forbid or proscribe advocacy of the use of force or of law violation except where such advocacy is directed to inciting or producing imminent lawless action") (emphasis added).

229. A rough analogy to the hearsay rule may clarify the point. Assume a prosecntion under a statute forbidding the hatred of a fellow citizen based upon his or her ethnicity or place of origin. Testimony that the defendant called the victim a "mick" or a "honkey" on a given day would not be hearsay because it would not go to prove the truth of either statement. The testimony would tend to prove the defendant illegally hated his fellow citizens. Thus is the social meaning of a phrase conveyed and understood. It is simply wrong to say that "mick" and its ilk have no meaning. They do. They mean, roughly speaking, "I hate you because you are $(\mathrm{X})$ and $(\mathrm{Y})$."

230. See supra text accompanying notes $107-16$ \& 122-30. 
define as false ideas to which they do subscribe). Not surprisingly, Justice Holmes recognized this in his famous dissent in Gitlow v. New York, where he contended:

Every idea is an incitement. It offers itself for belief and if believed it is acted on unless some other behef outweighs it or some failure of energy stifles the movement at its birth. The only difference between the expression of an opmion and an incitement in the narrower sense is the speaker's enthusiasm for the result. Eloquence may set fire to reason. ${ }^{231}$

Holmes' skepticism is reflected in a long line of cases deeming the offense caused by the expression of ideas to be insufficient to justify regulations of speech. Justice Douglas, for example, staked out this position im Terminiello v. Chicago:

[A] function of free speech under our system of government is to invite dispute. It may indeed best serve its high purpose when it induces a condition of unrest, creates dissatisfaction with conditions as they are, or even stirs people to anger. Specch is often provocative and challenging. It may strike at prejudices and preconceptions and have profound unsettling effects as it presses for acceptance of an idea. That is why freedom of speech, though not absolute, is nevertheless protected against censorship or punishment ... . There is no rooin under our Constitution for a more restrictive view. For the alternative would lead to standardization of ideas either by legislatures, courts, or dominant political or community groups. ${ }^{232}$

This notion also underlies Justice Jackson's famous contention that "[i]f there is any fixed star in our constitutional constellation, it is that no official, high or petty, can prescribe what shall be orthodox in politics, nationalism, religion, or other matters of opinion."233 This is the notion that compels us to allow other citizens to burn the flag. ${ }^{234}$ If we are to stay true to these principles, we must forbear froin regulating speecl that offends a group on the basis that it articulates an idea that is anathema to the group.

The Court today expresses its refusal to linit speech on the basis of offense to listeners largely through the requirement of content-neutrality. In fact, in recent years the inquiry into whether the challenged regulation is based on listener offense (to an idea) has come virtually to define the content-neutrality inquiry. In United States v. Eichman, ${ }^{235}$ the Court struck down the Flag Protection Act of 1989,236 in spite of the govern-

231. 268 U.S. 652, 673 (1925) (Holmes, J., dissenting).

232. 337 U.S. 1, $4-5$ (1949) (citation omitted).

233. West Virginia State Bd. of Educ. v. Barnette, 319 U.S. 624, 642 (1943).

234. Texas v. Johnson, 491 U.S. 397, 415 (1989) (offering Justice Jackson's quotation from Barnette in support of decision to strike down Texas flag burning statute).

235. 110 S. Ct. 2404 (1990).

236. 18 U.S.C. $\S 700(1990)$. 
ment's attempt to craft the law in a way that would be content-neutral. ${ }^{237}$ The Court found that the government's interest was "in the communicative impact of flag destruction" and was therefore impermissible. ${ }^{238}$ Similarly, im Boos v. Barry, ${ }^{239}$ the Court struck one part of a statute but not another because although the second part (as narrowed by the court of appeals) regulated only those protests that seriously threatened to disrupt the normal business of a foreign embassy, ${ }^{240}$ the first part sought to limit speech that brought a foreign government into "public odium or public disrepute."241 The Court found that the first part of the statute was not content-neutral because it "focus[ed] on the direct impact of speech on its audience," ${ }^{242}$ namely, the harm that speech critical of a foreign government imight do to the dignity of employees of that government's embassy. ${ }^{243}$ In both Eichman and Boos, the Court reaffirmed that regulations aimed at speech which contains ideas offensive to a given audience will be viewed as violatimg content-neutrality.

\section{Offensiveness as a Barrier to Self-Governance}

The above argnment demonstrates that we carmot sustain these regulations in the face of marketplace skepticism. It does not, however, resolve the asserted conflict between such skepticism and the argument from democracy. Recall that the communitarian version of the argument in favor of speecli regnlations contended that speech offensive to constitutive elements of the listener's personality demed the listener "equal membership in the political community." 244 If the communitarian view truly identifies a conflict between marketplace theory and the argument from democracy, we obviously cannot strike the regulation simply by reference to marketplace theory. As we saw earlier, communitarian theory fails to sustain its claim to resolve an alleged conflict between skepticism and democracy, because commumities tend to define equality by reference to communty norms rather than objectively neutral criteria.

Apart from communitarian theory, however, a wide array of scliolars have used the argument that offensive speech is inimical to the participation vital to democracy as a justification for university restrictions on speech. These scholars stress that offensive speech may alienate the members of a social minority from society at large and thereby exclude

237. Eichman, $110 \mathrm{~S}$. Ct. at 2408.

238. Id. at 2409.

239. 485 U.S. 312 (1988).

240. Id. at 331 .

241. Id. at 316.

242. Id. at 321 .

243. Id.

244. See supra text accompanying note 213 . 
them from the political process, either directly, by virtue of their feelings of disaffection, or indirectly, through a diminished sense of personhood and self-respect caused by hearing offensive speech. ${ }^{245}$ Such diminished personliood, the argument goes, prolibits members of a social minority from participating effectively in democratic self-governance.

Professor Lawrence has made this argument a major part of his defense of regulations of racist speech, and his article on the subject provides an excellent background against which the argument may be tested. ${ }^{246}$ First, however, we must address his attacks on the notion that narketplace theory (at least as presently conceived) is useful in thinking about the first amendment and racist speech. Marketplace theory assuines that participants in the inarket are rational and will act in their own best interest. For consumers, this means buying the goods that give tliem the most utility, and for participants in the inarketplace of ideas, it means accepting the arguments that ineet the same standard, presumably those that seem to them to be correct. Those who claim that offensive speecli is inimical to democracy generally assert that this premise is undercut by the irrationality that offensive speech is said to introduce in the inarketplace.

Professor Lawrence offers a strong version of this argument, asserting that the inarketplace of ideas is irrational because "[r]acism is an epidemic infectimg the inarketplace of ideas and rendering it dysfunctional."247 He borrows from Professor Ely the notion that "courts slould interfere with the normal majoritarian political process when the defect of prejudice bars groups subject to widespread vilification from participation in the political process and causes governmental decisionmakers to inisapprehend the costs and benefits of their [own] actions."248 Combining these two notions, Professor Lawrence tlius makes the inost powerful frontal assault on marketplace theory possible: $\mathrm{He}$ argues that we inust regulate the market in order to save it. If he and lis fellow critics are right, needless to say, we cannot rely upon marketplace skepticism to reject regulations of offensive speech. We believe, lowever, that these scliolars are mistaken.

Professor Lawrence's position defines racism to exclude certain race-based determinations. In other words, unless his argunnent is flawed by the racism lie attacks, he inust assume the possibility of valid premises for an arguinent concerning race, whicl can only be premises untainted

245. Post, supra note 76 , at $336-41$.

246. See Lawrence, If He Hollers Let Him Go: Regulating Racist Speech on Campus, 1990 DUKE L.J. 431.

247. Id. at 468 .

248. Id. at 470; see J. Ely, Democracy and Distrust: A Theory OF Judicial Review 152-58 (1980) (arguing courts should give heightened protection to the interests of minorities systematically excluded from the political process). 
by racism. Indeed, it would be impossible to have a debate over campus speech regulations unless one can classify speech by reference to racial content without actually being racist. Professor Lawrence's argument is problematic at this level, however, because it proves far too much. His argument undercuts the possibility of rational, nonracist discourse on issues of race. ${ }^{249}$ This is a minor point, but it is an important one. If every position taken in a debate over race relations with which Professor Lawrence (or anyone else for that inatter) disagrees is "racist," the inarket failure he asserts is grossly overstated, indeed nonexistent. One would not say that the inarket was infected by racism, but rather that the existence of a inarket (ineaning coinpeting ideas on a racial topic) both constituted and was proof of racism. Things begin to get circular at this point. If racism infects all thought on the topic then we cannot advocate a theory of speech at all, uuless we simply decide to iguore the charge that our theory is racist. There is an enormous difference between the use of racial invective and, for example, argunig that universities should not be allowed to reserve soine scholarship funds solely for minority students. ${ }^{250}$ The existence of nonracist premises (which at this point we simply assert do in fact exist), however, disproves Professor Lawrence's assertion, at least to soine extent, by demonstrating that the existing, unregulated market can generate ideas untainted by racism. We cannot accept an equation between such an argument and invective, nor do we beheve Professor Lawrence intends such an equation. We beheve that it is possible to discuss race relations without being racist, though the scope of such speech is indeterminate and speech at the margins will undoubtedly be interpreted as racist by some.

Past such preliminary skirmishes, the arguinent runs into even greater difficulty because, especially as Professor Lawrence puts it, the argument is misstated as an attack on the marketplace theory per se. It is not that. Rather, it is an expression of dissatisfaction with the degree to which "consuiners" of ideas in the market choose to adhere to racisın-the critics are unhappy with racism's relative market share. ${ }^{251}$ It is extremely risky to presunie a market failure, however, with no more evidence than the relative market shares at any given point in time. Twenty years ago the notion that Japanese manufacturers might gain a substantial share of the American automobile inarket would have seemed improbable at best. There should be hittle doubt that the idea that racism is bad is both widely argued and almost universally recoguized, even if

249. Unless, of course, one considers racist ideas rational.

250. See, eg., Rights Commission Asks Bush to Back Minority Scholarships, Wash. Post,'Jan. 26, 1991, at A3 (discussing criticism of Education Department's ban on race-specific scholarships).

251. See, e.g., Lawrence, supra note 246 , at $467-69$ (stating that "ever since the market opened, racism has remained its most active item in trade"). 
not universally accepted. Given this, the argument necessary to cast Professor Lawrence's dissatisfaction with racism's relative market share as a market failure is untenable.

Professor Lawrence, for example, assumes the irrationality and moral repugnance of racisn, and we cannot see how anyone could disagree with him on that issue. Nevertheless, it seems clear that the erudition that allows Professor Lawrence to argue so eloquently for restrictions on offensive speech is best acquired in a relatively open marketplace of ideas, run largely according to the hibertarian principles advocated here. The widespread dissemination of arguinents of advocates for Professor Lawrence's position seem to us to undermine the notion that the marketplace is incapable of dealing with issues of race relations. Nevertheless, by effectively seeking to coinpel agreement with his views by eliminating competing views from the market, his proposal threatens to undermine the free speech structure that fostered its intellectual foundations in the first place. ${ }^{252}$

The argument also suffers from a significant contradiction in the view of the market it must assume if it is to succeed. This contradiction undermines the ability of critics to claim that they know the objective truth regarding race relations, and at the same time undercuts their ability to claim with any degree of rigor that people with opposing views are wrong. Professor Lawrence asserts that all people are racist, and that racism is $\mathrm{m}$ part unconscious and therefore not susceptible of change through reasoned discourse, inaking reliance on marketplace theory strictly a non sequitur. ${ }^{253}$ The problem with this analysis is that if true, it undermines his adoption of Professor Matsuda's assertion that "[r]acial supremacy is one of the ideas we have collectively and internationally considered and rejected."254 If Professor Matsuda's assertion is correct, then Professor Lawrence's assertion that the marketplace is pervaded by racism, which renders it imcapable of efficient operation, is simply wrong.

If Professor Lawrence's theory of pervasive racisin is correct, however, his assertion that society has rejected racist beliefs is wrong, and we suddenly find ourselves with substantially less ground to believe that Professor Lawrence has identified the objective truth about race relations, and therefore less ground to believe that we have "inisap-

252. Because his real objection is to racism's share of the marketplace of ideas, Professor Lawrence's solution stands little chance of solving the problem of racism. It is possible, perhaps, that government participation in the marketplace (by advocating egalitarian principles and condemnimg racism) could decrease racism. Such possibilities are discussed at infra text accompanying notes 303-64.

253. Lawrence, supra note 246 , at $468-69$.

254. Id. at 463 n.119 (citing Matsuda, supra note 21, at 2360); see also Post, supra note 76, at 315. 
prehend[ed] the value of ideas in the market."255 Indeed, if any significant part of society lias considered but not rejected racist beliefs, tlien Professor Lawrence lias no basis for claiming that lie has identified a market failure. Professor Lawrence cannot truly call tlie disparity between his view of race relations and what he (probably accurately) describes as tlie current structure of the market a "market failure" unless he can postulate a source of truth outside the market, and a nonmarket criterion for claiming that what he has found is the truth.

Ratlier tlian attempt to do so, liowever, he asserts that racism's market share is something he has already said it is not, and he uses this to argue that the market is hopelessly flawed. This contradiction does not mean that there is a reasonable question whether racism is irrational or evil; there is not. It does mean, however, that if we are to justify regulations of offensive speech, we must look beyond the assertion that there is a consensus that racism is irrational and evil. The simple fact is that if the consensus were as he portrays it, we would not be engaging in this debate because incidents of racist speech would be neghigible. Such incidents are hardly neghible: they are pervasive even on campuses populated in large part by presumably intelligent people. We should instead recognize that the market itself yields at best ainbiguous results and is being used imconsistently by the proponents of regulation. As a result, the normal fears we feel when the government regulates the marketplace of ideas should be heightened.

Professor Lawrence does not limit his frontal attack on marketplace theory to the assertion that current market share reflects a failure to apprehend objective truth. He also asserts two related points, the second of whicll brings us to his argument from equal participation. Professor Lawrence's first point is that "[r]acist speech also distorts the inarketplace of ideas by ... devaluing the speecli of blacks and other nonwhites."256 This point need detain us only briefly, for it suffers from the saine flaw as his earlier points. It assumes an objectively discernible normative value for sucli speech but offers no way to ascertain that value that does not suffer froin the inarket flaw the argument is intended to remedy, nor any objectively derived criterion to distinguish his favored value from its coinpetitors (which of course include the unregulated inarket share). Moreover, his is an extraordinarily broad assertion. Not all speech is of equal value, and if we are to deem a histener's choice to disregard soine speecli as racist, we are at least entitled to some proof, even if only a contextual description, of that point. ${ }^{257}$ Just as the antitrust laws

255. Lawrence, supra note 246 , at 470 .

256. Id. It seems safe to assume that Professor Lawrence would extend this reasoning to social minorities who happen to be white, such as homosexuals. See id. at 471 n.147.

257. Professor Lawrence offers as evidence for this assertion exit polls from two recent elections 
protect "competition, not competitors,"258 marketplace theory does not demand that everyone who wants to speak must be heard, but only that everything worth saymg must be available to be heard, ${ }^{259}$ or, to borrow Justice Brennan's classical formulation, debate must be "uninhibited, robust, and wide-open."260 Thus, while the market's choice to ignore the speech of certain individuals has significant implications for deınocratic theory, it does not constitute a per se failure of marketplace theory (though it may be evidence of such a failure).

Moreover, there is at least some reason to doubt that Professor Lawrence's assertion is true in any broad sense. We believe it is fair to assume that inost ideas are available in the marketplace for those who wish to seek them out. Certainly the notion that racism is bad is available to all citizens at virtually no cost. Indeed, according to Professor Lawrence, it is a pervasive cultural truisin. Access to inore refined and sophisticated ideas entails greater information costs, and thus relatively fewer people will seek it, but that does not mean that those ideas are not available in the inarket. ${ }^{261}$ While this argument could easily become circular (any idea one could inention to refute it would by definition be available in the market), we believe it is valid to prove the narrower point that exclusion of soine potential speakers does not necessarily alter the availability of ideas. A market does not fail because people decline to adhere to a given set of ideas that the market makes available. A market does fail when it is prevented froin making available certain ideas to whicl people might wish to adliere. The function of a inarket is to provide choices, not compel them.

We inust also remeinber that we speak of the marketplace as frozen in time, but actually it is not. Different ideas are ascendant at different times in history; the refinement of theory and argument is the innovation of the intellectual inarketplace, and new theories alter the structure of the inarket over time as do new products. As Judge Easterbrook put it, "[a]t any time, soine speech is ahead in the gaine; the inore numerous

which showed more whites claimed to have voted for the African American candidates than actually did so. Id. at $471 \mathrm{n} .147$. There is no reason to believe, however, that this constitutes evidence that the voters devalued the African American candidates' speech, or, for that matter, that it says anything else at all about speech. One may at least argue, and we believe persuasively, that the polls say more about whites' desire not to appear racist (regardless of whether they were) than it does about speech. Professor Lawrence's conclusion simply does not follow from the results of the polls.

258. Brown Shoe Co. v. United States, 370 U.S. 294, 320 (1962).

259. A. Meixlejohn, Political Freedom: The Constrtutional Powers of the People 26 (1948).

260. New York Times Co. v. Sullivan, 376 U.S. 254, 270 (1964).

261. In this sense, the cost of information in the marketplace of ideas serves the same function as does price in real markets; more sophisticated ideas will be sought only by those for whom access to those ideas yields sufficient utility to justify the cost. 
speakers prevail."262 Finally, given the foregoing, it is fair to say that Professor Lawrence's argument rehes primarily upon the value of speech in the self-realization of the speaker. As we noted above, however, such arguments are not, properly speaking, arguments for free speech at all. In its typical form, the argument from self-realization is nothing more than an undifferentiated argument for liberty. Here the argument is reversed, as it takes the form of an undifferentiated claim to be treated with equal dignity by others in society. That version of the argument, however, is no more an argument about free speech than is its counterpart. That is to say, Professor Lawrence's argument is one about the existence of racism and racist practices. It has little to do with speech per se, and indeed, it ignores the unique danger posed by ceding to the government the ability to determine what speech is true.

Professor Lawrence's second point is that racist speech silences members of social minorities and therefore excludes their voices from the marketplace of ideas. ${ }^{263}$ Here his argument dovetails with the broader contention that racist speech is imconsistent witl democracy to the extent it alienates members of social minorities from the political process and thus denies them the right of political self-determination. ${ }^{264}$ In Professor Meiklejolin's elegant terms:

[I] $n$ the deeper meaning of the Constitution, voting is inerely the external expression of a wide and diverse number of activities by means of which citizens attempt to ineet the responsibilities of inaking judgments, which that freedoin to govern lays upon them. That freedom imphies and requires what we call "the dignity of the individual." Self-government can exist only insofar as the voters acquire the intelligence, integrity, sensitivity, and generous devotion to the general welfare that, in theory, casting a ballot is assumed to express. ${ }^{265}$

Thus, the argument goes, we need not protect offensive speech because "[t]he purposes of collective self-determination require ... that public action be founded upon a public opinion formed through open and interactive processes of rational deliberation."266

There is good reason to question whetler offensive speech truly renders social minority groups outsiders incapable of participating in collective self-determination. In the first place, there are wide areas of democratic choice in which an individual's status as a member of a social ininority group most likely will be relatively less important than some other cliaracteristic slie possesses. That a person is a member of a social

262. American Booksellers Ass'n v. Hudnut, 771 F.2d 323, 331 (7th Cir. 1985), aff'd per curiam, 475 U.S. 1001 (1986).

263. Lawrence, supra note 246 , at 471 \& n. 147.

264. See Post, supra note 76, at 330-35.

265. Meiklejohn, The First Amendment is an Absolute, 1961 Sup. CT. REV. 245, 255.

266. Post, supra note 76 , at 326 . 
minority group should have little to do with, for example, her views on the regulation of energy, or whether to increase taxes, pursue alternative forms of energy, or pass stricter laws against pollution. To the extent that in large areas of policy an individual's identity as a inember of a social minority is less relevant than other characteristics, therefore, there is a broad range of debate in which offensive speech is relatively less likely to be used and in which there is a somewhat lesser chance that neinbers of social minorities will be deterred froin participating.

Within the set of policy choices that overtly consider race, however, the argument must be considered directly. At the risk of appearing simple, we note initially that the debate over these regulations is controversial precisely because various social minority groups have been able, by reference to the relevant political processes, to get regulations enacted protecting thein froin such speech. Indeed, social minority groups have been sufficiently successful in obtaining protective regulations that at least one of thein has been stricken as unconstitutional. ${ }^{267}$ To that extent, at least, we may say that although offensive speech is demeaning and perhaps interferes with the ability of meinbers of a social minority group fully to realize their personality, such speech does not exclude thein from the pohtical process nor prevent thein from becoining part of effective political inajorities that implennent sanctions against such speech.

This answer seeins satisfactory at least with respect to the cainpus environment. All the theory in the world camiot supplant the actual success of social minorities in obtaining protective, if not overly protective, speech regulations, and this success adequately refutes the theoretical construct which clainis they should not be able to do so. This does not answer the question completely, however. As we discuss in greater detail below, ${ }^{268}$ the university is in many respects different from the rest of society, and the success of social ininorities there may not transfer to state and national politics. It is possible that the emotional dannage inflicted upon members of social ininorities while they are on campus alienates thein from society at large and thus effectively prevents them from participating in deinocratic self-governance in those larger arenas. Although this arguinent possesses considerable force, it ultinately does not justify regulation of offensive speech.

We begin by acknowledging what should be obvious, and what Professors Lawrence, Matsuda, and Delgado have stated. Society incurs significant social costs when we forbid universities (or cities or states, for that inatter) from regulating offensive speech directed at ineinbers of social ininorities. Whenever a minority student is driven out of a univer-

267. See, e.g., Doe v. University of Mich., 721 F. Supp. 852 (E.D. Mich. 1989).

268. See infra notes $365-85$ and accompanying text. 
sity by a hostile racial climate, which includes offensive racial speech, that student pays the price of preserving marketplace skepticism. Even if the student transfers to another umiversity, the student pays a cost because the student has been forced to accept his or her second-choice school, which is presumably of less utility to the student than the original school. ${ }^{269}$ Whenever a member of a social minority feels too frightened to voice her opinion because she fears racist responses, the student pays the social cost of preserving marketplace skepticism. Though we state the argument in economic terms to preserve the metaphor, the cost we speak of represents feelings of humiliation, degradation, and ahenation. The question is how to combat such costs, and im particular whether they justify governmental constriction of the marketplace. We beheve the answer is no.

Initially, we must note that "equal membership in the political community" means something very different than equal opportunity to participate in the political process. The phrase is used to denote a level of substantive equahty, generally a level to be achieved through the differential treatment of social minority groups. Democracy, however, does not require-and could never obtain-absolute individual equahity. Some voters, for example, are simply smarter than others; even voters of equal intelligence may have different imterests such that they are more or less willing to bear the cost of becoming relatively more informed on any given issue. This argument reflects a more Aristotehian notion of equality-equality as proportion rather than as similar treatment simpliciter. Additionally, to uphold a regulation based upon individual inequality would require us to identify the characteristics differentiating the offense experienced by different groups, which, as we have seen, is an elusive task. A.t one level, we may say that when faced with relatively marginal conflicts such as the one posed by offensive speech, we prefer marketplace skepticism to a strong version of equality because to do otherwise would sarnitize the marketplace such that participation in it would be approximately equal but frivolous.

There is nore to the arguinent than this, however. Persons offended by racist or homophobic speech, for example, are, in an adimittedly formal sense, treated precisely the same as any other person. Thus, should they wish to reply with equally offensive speech, they are free to do so. Should they choose to respond with rational discourse deinonstrating the irrationality of the prior insult, they may do so and all concerned will be

269. To this limited extent, therefore, it is incorrect to say that "[c]ombating racial discrimination and protecting free speech should be viewed as mutually reinforcing, rather than antagonistic, goals." Strossen, Regulating Racist Speech on Campus: A Modest Proposal?, 1990 DUKE L.J. 484, 489. While the point may be accurate in the long run-due to the tendency of a strong first amendment regime to foster tolerance-that does not mean that such a regime does not impose short-term social costs. 
the better for it. This treatment comports with at least one notion of equality, and it reflects the Court's usual methodology in first amendment cases. ${ }^{270}$ The question then becomes whether formal equality is so insufficiently protective of the sensibilities of social minority groups that members of such groups camiot use meaningfully the protections of the first amendment.

This is a difficult question to discuss in the abstract. Speech that is offensive to members of social minorities might well cause them to feel alienated from society, but it does not follow that they will stop participating in the process of self-governance. We find it difficult to beheve, for example, that members of social minorities who otherwise would do so will decline to vote because of the absence of racist speech regulations, or even because they were the subject of epithets. We find it equally unlikely that offensive speech will stop parades, speeches, petitions, letter-writing campaigns, or any of hundreds of other ways in which social minorities attempt to brimg political majorities around to their point of view. Historically, such abdication has not been the case. ${ }^{271}$ If anything, one might expect the use of invective to stir social ininority groups to dennand redress froin political leaders. There is simply no reason to beheve that absolute (or even substantial) freedoin from einotional distress is a precondition of a democratic society.

Apart from theoretical probabilities, this debate asks a largely empirical question that simply is not susceptible to syllogistic resolution. Perhaps the most we can say is that to einpower social minority groups sufficiently for their members to feel free to take advantage of their first amendment rights we inust grant the government the power to determine both the degree of offensiveness beyond which speech may be regulated, and the validity of the felt offense- whether the social minority is normatively justified in feeling offended by any given type of speech. These powers are enormously broad; assuming no group may justifiably claim protection froin the offense they feel froin "true" speech, ${ }^{272}$ they include ceding to the government the power to determine the truth or falsity of speech. There could be no plainer violation of marketplace theory. To borrow agam from Judge Easterbrook:

A power to limit speech on the ground that truth has not yet prevailed

270. See Posadas de Puerto Rico Assocs. v. Tourism Co., 478 U.S. 328, 341 (1986).

271. See, e.g., Gregory v. City of Chicago, 394 U.S. 111, 113-30 (1969) (Black, J., concurring). Justice Black's concurrence describes a march led by civil rights leader Dick Gregory to the home of Mayor Richard Daley, which the marchers then picketed. The opinion also describes in general the public demonstrations for equality prompted by Brown v. Board of Education, 347 U.S. 483 (1954). Gregory, 394 U.S. at 114; see also, H. KALVEN, JR., THE NEGRo AND THE FIRST AMENDMENT (1966).

272. American Booksellers Ass'n v. Hudnut, 771 F.2d 323, 330-31 (7th Cir. 1985), aff'd per curiam, 475 U.S. 1001 (1986). 
and is not likely to prevail implies the power to declare trutli. At some point the government must be able to say ... "We know what the trutl is, yet a free exchange of speecl lias not driven out falsity, so that we must now prohibit falsity." If the government may declare tlie truth, why wait for the failure of speecli? Under the First Amendment, lowever ... the government may not restrict speech on the ground that in a free exchange trutli is not yet dominant. ${ }^{273}$

In the absence of compelling evidence mdicating that the marketplace hiterally cannot function without such regulations, the risks inherent in allowing the government so much latitude justify rejecting the argument for restrictions, even if there is a cost in terms of overall participation.

Our final observation about offensiveness goes not to the role of the marketplace but rather to the nature of the society for which it operates. As we have seen, scholars with both commumitarian ${ }^{274}$ and selfgovernance $^{275}$ orientations argue that offensive speech denies members of minority groups equal nenubership and participation in governing the community. As the above arguments demonstrate, the clann is inore about the participation of groups than the participation of any individual within those groups. Professor Lawrence's assertion that the market systematically undervalues the speech of minorities ${ }^{276}$ takes as its premise that the problein stems from the speaker's group membership and not from what she is saying.

The kind of remedy that those seeking speech restrictions desirc reinforces the notion that it is fundamentally groups and not individuals who are at stake. Professor Grcy speaks of the symbohc value that offensive speech restrictions have in putting a university on record as opposing such speech. ${ }^{277}$ Professor Post similarly notes that such restrictions would act as a gesture of inclusion towards historically excluded groups. ${ }^{278}$ While these certainly may be laudable goals, such groupbased conceptions are fundamentally at odds with the premises underlying American society, which privileges the individual over the group. Writing in the 1989 Nebraska Symposium on Motivation, psychologist Harry Triandis discussed the factors that give content to the concepts of "individualism" and "collectivism," as well as the conditions that lead a society to develop along one line or the other. ${ }^{279}$ Triandis describes an individualist culture as one in which "most people's social behavior is

273. Id.

274. See supra note 213 and accompanying text.

275. See supra notes $263-65$ and accompanying text.

276. See supra note 256 and accompanying text.

277. See T. Grey, supra note 8, at 38; see infra notes 298-302 and accompanying text.

278. See Post, supra note 76, at 312-17; see infra notes 298-302 and accompanying text.

279. Triandis, Cross Cultural Studies of Individualism and Collectivism, in 37 CuRrent TheORy and Research Motivation: Nebraska Symposium of Motivation, 1989, at 41 (J. Berman ed. 1990). 
largely determined by personal goals that overlap only slightly with the goals of collectives, such as the family, . . . coreligionists, . . . and the state."280 Individualism predominates in societies that are both culturally complex and affluent, ${ }^{281}$ and evolves out of collectivism in those societies that move from agrarian to industrial economies. 282 The United States, not surprisingly, is "among the inost individualistic cultures of the world." 283

Individualism is not without its costs; for Triandis it "works well in economics, but not as a philosophy of life."284 It is in fact consistent with a justification of racism through the affirmation of the status quo. ${ }^{285}$ However, collectivism is also consistent with the toleration of "considerable mequality when dealing with outgroup members,"286 probably for the reasons outlined above. ${ }^{287}$ Perhaps inost importantly, individualism is strongly associated with belief in individually arrived at, as opposed to group determined, trutll. The corollary is that in collectivist cultures, it is commonly understood that "the group that possesses the truth should run things."288

Social science research thus provides descriptive support for the individualist assumptions that ground much first amendment theory. This is not to argue normatively that one type of society is preferable to another (if for no other reason than that the criteria of preference are likely to be societally contingent). It is to point out that since our society is demonstrably premised on the behef that the person, rather than the group, is the relevant social unit, ${ }^{289}$ offensive speech restrictions derived from rationales which privilege group over individual rights will run counter to many of our most fundamental premises.

\section{Offensiveness and the Neutrality Problem}

A related question arises from proposals that regulate all speech reaching a certain level of offensiveness but that effectively would apply only to majority-group speakers offending minority-group listeners. These proposals would not sanction even demeanimg invective issued by a minority-group member against a majority-group listener. While none of the university regulations discussed above propose such structures, both

280. Id. at 42 .

281. Id. at 44 .

282. Id. at 71 .

283. Id. at 44 .

284. Id. at 101.

285. Id. at 102 .

286. Id. at 103.

287. See supra notes 196-216 and accompanying text (outlining weaknesses of communitarian theory).

288. Triandis, supra note 279, at 103.

289. Id. at 101 (citation omitted). 
Professor Grey and Professor Matsuda have done so. ${ }^{290}$ Professor Grey's regulation is offense-based, and he justifies his departure from the neutrality normally required by the first amendment by reference to the differential offense levels he beheves are associated with different slurs. For Professor Grey, this inquiry is tied to the differential social power of the relevant groups. As he puts it:

[T] here are no epithets in this society at this time that are "generally understood" to convey hatred and contempt for whites (or men, or heterosexuals) as such. This is no accident; the racial and other epithets covered by the rule are able to inflict so serious and distimctive an mjury because they are tied to ineınbership in groups subjected to long-standing and deep-rooted prejudices widely held and disseminated by the dominant culture of this society.... The racist and other epithets draw their capacity to inpose special mjury from their tendency to turn the whole socially and historically inculcated weight of these prejudices inward upon their victim. ${ }^{291}$

It is perhaps an exaggeration to say that "honky," for example, is not "'generally understood' to convey hatred and contempt for whites." 292 Professor Grey's argument rehes more on the proposition that, due to the historical differences in the sociological positions of whites and social minority groups in the United States, members of social minorities are more susceptible than whites to real emotional injury from an epithet. Conceding that no white called a honky could ever suffer real emotional injury (especially, perhaps, a very hiberal white who prided himself on his sensitivity to racial concerns), it does seem fair to say that epithets directed against menibers of social minority groups are niore likely generally to cause severe harm. The problem remains, however, that such a harm-focused inquiry is most appropriate to an "inherently inciting" analysis, which Professor Grey rejects. While it is possible to argue that no white could ever be hurt, it would seen that such an inherently empirical determination is ill-suited to such a categorical assertion. It seems a more prudent and constitutionally sounder course not to exclude insults against whites on a per se basis.

Professor Matsuda adds an additional, psychological justification: "I would interpret an angry, hateful poem by a person fron a historically subjugated group as a victim's struggle for self-identity in response to racism."293 Thus, Professor Matsuda apparently would presume that

290. T. Grey, supra note 8, at 23-24; Matsuda, supra note 21, at 2361-62.

291. T. Grey, supra note 8, at 23-24. Professor Delgado has expressed similar sentiments. See Delgado, Words That Wound, supra note 21, at 180 (noting that under his proposed scheme only rarely would a white plaintiff recover tort damages for insults from a minority defendant).

292. T. Grey, supra note 8, at 23.

293. Matsuda, supra note 21, at 2361-62. She concludes, "Part of the special harm of racist speech is that it works in concert with other racist tools to keep victim groups in an inferior position." Id. at 2362. 
racist statements by minority group members against majority group members could not be made with a specific intent to harm the majority group member. This argument strikes us as essentially an empirical prediction that is based upon a well-defined view of the effect of social status on the members of social minority groups. As phrased, Professor Matsuda's presumption appears directed more toward what we commonly think of as motive rather than specific intent. A member of a social minority might well intend to insult and injure a white person through speech, yet be motivated by his own inner pain and frustration. In a typical legal analysis, motive would not excuse otherwise sanctionable conduct. Rather, the person would be held to have coininitted all the elements of the offense and then would have the opportunity to offer a motive-based excuse or defense.

From a first amendinent perspective, however, this approach is problematic. It focuses on the role of speech in the process of the speaker's self-realization, which as we have seen is not a justification for protecting speech at all. Moreover, while in any given case the white histener's personality may be degraded by an epithet to a lower degree than the social minority would benefit through the cathartic effect of speech (thus yielding a "net benefit" in self-realization), there is no reason to presume that this is the case. Because Professor Matsuda's view on this point fails to distinguish speech from other forms of activity that could lead to catharsis, her arguinent fails to offer a justification for protecting speech beyond that which could be offered for other cathartic activities (such as punching a bigot), and by the same reasoning fails to offer a justification for excepting the offensive speech of minority group members from an otherwise apphicable speech restriction.

Furthermore, we are skeptical of the abihity of this approach to support a departure from the norm of content-neutrality for two reasons. To return to Professor Grey's views, we see that his argument focuses upon the role of race or gender in constituting the personhood of prospective listeners in much the same way as did the communitarian effort to cabin the scope of offense-based restrictions. One of the probleins we saw with such efforts, however, was that the focus on constitutive elements of personhood is logically neutral-race is constitutive for both minorities and whites. Thus, since Professor Grey's argument cannot turn on the role of race in constituting personhood simpliciter, he must justify the departure from neutrahity in terms of the severity of the listener's injury.

Unfortunately, Grey does not atteinpt a justification at this level, and as we saw above there is no principled way that we can merely assume that only speech denigrating minority groups rises to whatever level we decide justifies the regulation of speech. As a practical matter, such differences as may exist in individual cases probably would be 
reflected in differential jury awards for white and minority plaintiffs, ${ }^{294}$ but this provides no basis for blanket regulations. Worse, Grey's argument proves far too much. His proposed regulation would prohibit, roughly speaking, racist speech that would immediately incite violence and private offensive speech, yet it would not do so neutrally. ${ }^{295}$ The premise that a certam level of harm to personhood justifies a departure from neutrality supports such a departure in every instance-regardless of whether the speech is public or private and regardless of whether the offense comes from an idea the histener perceives as offensive.

Indeed, the justification turns primarily upon the ideas invoked by the words Professor Grey wishes to prohibit. Grey admits that the words inflict injury primarily because they are tied to "long-standing and deep-rooted prejudices widely held and disseminated by the dominant culture."296 His justification thus violates the skepticism of marketplace theory. Grey, however, freely admits this violation. His departure from neutrality is an express accommodation to the "civil rights perspective" (as opposed to the "civil liberties perspective"), in which "there are false ideas and ideologies, among which white suprenacy and related forms of bigotry are the paradigm examples."297 We will not repeat again the response dictated by inarketplace theory other than to note that we beheve it is dispositive of this argument.

Grey beheves, however, that this intrusion into inarketplace theory is justified by the symbohic value that a nonneutral regulation will carry. ${ }^{298}$ As he puts it, "when a university administration backs its antiracist pronouncenients with action, it puts its money where its mouth is. . . A Authorities nuake the inost effective statement when they are honestly concerned to do soinething beyond making a stateinent."299 This argument is exceedingly curious. ${ }^{300}$ Assuming for the moinent that his departure from neutrality violates current first amendinent doctrine (as we beheve he would concede), he attempts to justify that violation simply by reference to the utilitarian conclusion that the violation is marginally

294. Cf. Post, The Social Foundations of Privacy: Community and Self in the Common Law Tort, 77 CALIF. L. REV. 957, 967 (1989) (noting the role of jury awards in vindicating plaintiff' bringing invasion of privacy claims).

295. T. Grey, supra note 8, at 14-16.

296. Id. at 23.

297. Id. at 25 (emphasis in original).

298. Id. at 36 ("I concede that the main purposes behind the proposal are in a certain sense educative or symbolic.").

299. Id. at 38 (einphasis in original).

300. Professor Post considers a similar argument. See Post, supra note 76, at 312-17. Post notes that the act of restricting racist speech would be a "gesture of social esteem" designed to meet the needs of "those who feel alienated." Id. at 131. Professor Post, however, rejects the argument as a justification for restricting racist speech because he correctly perceives that it is not susceptible to principled limitation and would lead to the restriction of an excessive ainount of speech. Id. at 31617. 
acceptable in light of the symbolic benefit. ${ }^{301}$ That argument, however, not only begs the real marketplace question-which is who decides precisely that question-but it also attempts to weigh clearly incommensurate values. ${ }^{302}$

The value underlying marketplace tlieory is probably best characterized as the pubhic interest in bemg free from potentially erroneous governmental determinations of truth. That value generates a skepticism which in turn prohibits, as absolutely as anything can be prohibited in our constitutional system, the governinent from making determinations on what the citizenry may believe. Against that value Grey seeks to weigh the value entailed in having the university deinonstrate its commitment to combating racism by doing more than implementing a counterspeech policy. Even assuming that we may disregard marketplace theory for the moment, Grey leaves us no principled way to support his departure from neutrahty beyond his preference for the result. Ultimately, therefore, the departure is not justified. Although the aphorism that the remedy for bad speech is more speech sounds cliché, it is particularly apt with respect to this situation. The skepticisin of marketplace theory leaves us no other choice.

The conclusion that offense-based regulations are inpermissible under the first amendment is frequently disputed by commentators who beheve that there is a realin of truth that may be defined by the state and enforced through limitations on speech. Such arguments, however, are best addressed through the prism of stigma-based regulations.

\section{Regulations Designed to Prevent Stigma}

On March 1, 1989, the Stanford Student Conduct Legislative Council proposed a campus speech regulation that provided that "[m]einbers of the Stanford commumity have the right not to be inescapably and mvoluntarily exposed to ... forms of expression that by accepted community standard stigmatize, victimize, or pejoratively characterize per-

301. We assume here that Grey could limit his incursion into marketplace theory only to determining that the ideas invoked by racial or gender-based slurs are not true. While we may feel more comfortable if we decide the scope of the incursion that may be cabined, this fact provides no support for making the incursion in the first instance-it is merely an anticipatory response to a "slippery slope" argument. Grey can draw no more validity from his efforts to limit his incursion than could Texas in arguing that its flag burning statute was similarly limited. See, e.g., Texas v. Johnson, 491 U.S. 397, 421-35 (1989) (Rehnquist, C.J., dissenting). While Chief Justice Rehnquist's dissent in Johnson succeeds in establishing that the flag is a unique symbol, it fails to establish that the government properly could declare in the first instance that the flag could be shown respect but not contempt through the burning. Assuming that fiag burning is symbolic speech, it cannot be restricted without a prior governmental determination that the message conveyed is in some sense impermissible.

302. See, e.g., Shiffrin, supra note 48 , at 1249 n.240. ("the balancing metaphor implies that all values can ultimately be reduced to one measuring standard"). 
sons or groups on the basis of personal or cultural differences."303 The University of Michigan adopted a similar approach. ${ }^{304}$ These regulations attenipted to resurrect the largely dormant doctrine of group hbel, which allows a nieniber of a defamed group to sue a speaker for statenients made about the group generally, even absent a reference to any specific meniber of the group. ${ }^{305}$ Professor Matsuda attenipts to justify an exception to the normal rule limiting hibel recovery only to plaintiffs who were themselves defamed, by instead limiting recovery to instances in which the speech directed at groups denied the personhood of group members, and in which the group targeted is an historically oppressed racial group. ${ }^{306}$

The doctrinal support for the group libel exception to the first amendnent begins (and very likely ends) with Beauharnais v. Illinois. ${ }^{307}$ In Beauharnais, the Supreme Court uplield the crimmal conviction of the defendant, who had circulated a leaflet calling for the halt of the encroachment of African Americans into white neigliborhoods, decrying the "aggressions . . . rapes, robberies, knives, guns and marijuana of the negro," and spoke of the need to prevent the wlite race fron being "niongrelized by the negro." 308 The defendant was convicted under a statute proscribing the portrayal of the "depravity, criminality, uncliastity or lack of virtue of a class of citizens, of any race, color, creed or religion" if it was defamatory to the class or could tend to lead to a breach of the peace. ${ }^{309}$

The Suprenie Court first noted that the statute had been authoritatively construed by the state supreme court as a "form of criminal libel law."310 The Court began by citing language froin Chaplinsky to the effect that libel was one of the unprotected categories of speech, based on the state's mterest in preventing the breach of the peace that could flow fronı such libel.11 The Court recognized that the speech in question would be libelous if inade about a specific individual, ${ }^{312}$ and then concluded that an utterance which could be prohibited if directed at an individual could be prohibited if directed at a group. ${ }^{313}$ Having determined that Beauliarnais' speech fell into a category not worthy of first

303. Council Additions, supra note 13, at 21 (emphasis added).

304. Doe v. Umiversity of Mich., 721 F. Supp. 852, 853 (E.D. Mich. 1989).

305. See generally H. KALVEN, JR., supra note 271, at 7-64 (discussing Beauharnais v. Illinois, 343 U.S. 250 (1952), in particular, and group libel in general).

306. Matsuda, supra note 21, at 2357-58.

307. 343 U.S. 250 (1952).

308. Id. at 276.

309. Id. at 251.

310. Id. at 253 .

311. Id. at 255-57.

312. Id. at 257-58.

313. Id. at 258 . 
amendment protection, the Court proceeded to apply what was labeled a rational basis test to the statute. ${ }^{314}$ Far from making the sort of conclusory statement usually associated with rational basis scrutiny, however, the Court traced the significant history of racial tension and violence in Illinois, cited statistics regarding the racial makeup of the state, and argued at some length that the state should be allowed to experiment with arguably inefficacious remedies in attempting to solve so pressing a problem. ${ }^{315}$ The Court's discussion assumed that libels such as Beauharnais' would tend to cause breaches of the peace. ${ }^{316}$ Beauharnais was the last the Supreme Court heard of group libel. Later developments, however, have caused most coinmentators to question the validity of the case. ${ }^{317}$

Most importantly, New York Times Co. v. Sullivan ${ }^{318}$ established that not all hibelous speech is beyond the protection of the first annendment. New York Times' emphasis on falsity led the Court later to conclude that stateinents that could not be proven false could not support an action for defamation. ${ }^{319}$ Statements about supposedly generic tendencies of a given group hikely will be perceived as statements of opinion, because histeners will understand such statements as characterizations rather than as assertions of fact. ${ }^{320}$ Such statements would therefore

314. Id.

315. Id. at $258-63$.

316. Id. at $259-61$.

317. See, e.g., Kretzmer, supra note 21, at 449-50 \& n.27; Schauer, Codifying the First Amendment: New York v. Ferber, 1982 Sup. CT. REv. 285, 303 \& n. 100.

318. 376 U.S. 254 (1964).

319. Philadelphia Newspapers v. Hepps, 475 U.S. 767, 777 (1986).

320. Milkovich v. Lorain Journal Co., 110 S. Ct. 2695 (1990) (holding that statements that cannot be proven false are protected by the first ainendment). Even if the speech concerns supposedly generic characteristics, such as in Beauharnais, it may be interpreted as a statement of fact. This merely raises the question of the extent to which regulation of group libel is permissible under New York Times. Under New York Times, false statements of fact about a public official are not actionable unless made with "actual malice." 376 U.S. at 279-80. The "actual malice" test requires that the defendant must have either known that the statements were false, or have shown "reckless disregard" as to whether the statements were false. Id. at 280. The Court extended this protection to statements made about public figures in Curtis Publishing Co. v. Butts, 388 U.S. 130, 164 (1967) (Warren, C.J., concurring). Whether the protections of New York Times apply to the libel of groups depends $\mathrm{m}$ part on whether groups can be characterized as public figures.

In Gertz v. Robert Weich, Inc., 418 U.S. 323 (1974), the Court declined to extend the protections of New York Times to defamatory statements about private figures, even where the statement concerned a "public issue." Id. at 345-46. Instead, the Court concluded that, so long as some level of scienter remained an element of the tort, states were free to impose liability for a "defanatory falsehood injurious to a private individual." Id. at 347. The Gertz Court considered two main factors in determining that the first amendment did not substantially restrict libel suits by private figures. First, the Court noted that public figures, unlike private figures, had access to the media, and thus could counteract the harmful effects of libelous statements. Id. at 344. Second, the Court reasoned that public figures had consented to being discussed when they voluntarily chose to assume a role in public life, whereas private figures had not "thrust themselves to the forefront of 
receive full first amendment protection. ${ }^{321}$ Second, the post-Chaplinsky line of cases, as well as Brandenburg v. Ohio ${ }^{322}$ and its progeny, call into question the breach of the peace analysis of Beauharnais. Both lines of cases deal with potential restrictions on speech predicated on preventing a breach of the peace. Unlike Beauharnais, however, both lines of cases reject a mere "tendency" to cause a breacli of the peace and require soine showimg of an "imminent" or "clear and present" danger of such a breach actually occurring as an immediate result of the speaker's words. ${ }^{323}$

Beauharnais has not fared well in the courts either. In Collin v. Smith, ${ }^{324}$ the Seventh Circuit struck down time, place, and manner restrictions passed by the Village of Skokie ${ }^{325}$ that liad the effect of denying inembers of the American Nazi Party the right to hold a march. ${ }^{326}$ One of the ordinances specifically included language similar to that contamed in the statute uplreld in Beauharnais. 327 The Collin court expressed its doubts about the continuing viability of the "tendency to induce violence"328 prong of Beauharnais, citing Gooding, Cohen, and Brandenburg. ${ }^{329}$ It then questioned Beauharnais' otlier rationale-that libel is not constitutionally protected speech-in light of New York Times and its progeny. The court expressly rejected the argument that group libel could be regulated solely on the basis of its offensiveness without regard to its likelihood to lead to violence. ${ }^{330}$ The Suprenie Court denied

particular public controversies in order to influence the resolution of the issues involved." Id. at 344-45.

Applying these two factors to groups of individuals suggests that the underlying rationale for allowing private figures to recover in libel actions does not necessarily extend to a defamed group. To the extent that many groups in America are organized and represented by soine form of public counsel-for example, both the NAACP and MALDEF have legal departments, see 1 ENCYCLOPEDIA of Associations 1620 (Entry No. 14429), 1695 (Entry No. 15140) (D. Burek 25th ed. 1991)-and thus they have greater access to the media, and so a greater ability to rebut libelous remarks, than do individual private figures. It is also arguable that these groups, as groups, lave voluntarily "thrust themselves to the forefront of particular public controversies in order to influence the resolution of the issues imvolved." Gertz, 418 U.S. at 345.

321. Lorain Journal, 110 S. Ct. 2695.

322. 395 U.S. 444 (1969).

323. See also Terminiello v. City of Chicago, 337 U.S. 1 (1949) (dcaling witl a "heckler's veto" situation and lolding that a breach of the peace statute construed to prohibit any conduct which "stirs the public to anger, invites dispute, brings about a condition of unrest, or creates a disturbance" violated the first amendment). But see Feiner v. New York, 340 U.S. 315 (1951) (upholding a conviction in a seemingly sinilar situation, without discussing Terminiello).

324. 578 F.2d 1197 (7th Cir.), cert. denied, 439 U.S. 916 (1978).

325. Id. at $1207-10$.

326. Id. at $1199-200$ \& n.3.

327. Id. at 1199 .

328. Id. at 1204 .

329. Id.

330. Id. at 1205 \& n.15. 
certiorari. ${ }^{331}$ The constitutional soundness of Beauharnais is thus, at best, debatable.

Of course, if Beauharnais is no longer good law, then stigma-based restrictions are clearly unconstitutional to the extent they rely upon its premises. A preliminary problem facing any group libel proposal is the extent to which it is preempted by Gooding and Lewis, which rejected regulation of "opprobrious" language. ${ }^{332}$ To the extent that Beauharnais really was a breach of the peace case (with a higher than average risk based on unique historical facts), ${ }^{333}$ its state interest, and so its inquiry, can properly be conpared with the inquiry in Gooding and Lewis which rejected similarly "opprobrious" language. At least in analogous cases, a group libel sanction seeins particularly inappropriate. Additionally, we niust consider two niore theoretical points about sucl1 proposals.

\section{Stigma-Based Regulations as Restrictions on Thought}

The argument fronı stigma is structurally different from the argunent fronı offensiveness. The latter envisions a bipolar nodel of speecl1-sonieone speaks harmful words eitlier to or witlin earshot of the listener, who suffers liarm. Stigma-based arguments, however, are umique because they allow for the regulation of speech even where no members of the denigrated group are present to suffer inniediate offense. Stigma-based regulations therefore conteniplate an essentially triangular structure. On one axis, stigma-based regulations assert that a speaker may not defame a meinber of a group to his face because such speech could reinforce notions of inferiority in the listener; this type of stigma was the harm asserted to affect African American children in Brown v. Board of Education. ${ }^{334}$

On the second axis, stigma-based regulations assert that a speaker may not defame a group, even in the absence of any group members, because her audience might accept the defaniatory statenients as true. This furtlier ensconses racist views in the audience and, on the third axis, makes nienibers of the defanied group suspect in eyes of noninembers of the group. ${ }^{335}$ The ability to control this type of audience response is the unique benefit of group defaniation laws. Suclı laws are remarkable in

331. Smith v. Collin, 439 U.S. 916 (1978). One possible ray of hope for Beauharnais is that in his dissent from a denial of certiorari to an earlier iteration of the case, Justice Blackmun, joined by Justice White, pointed out that Beauharnais "has not been overruled or formally limited in any way." Id. at 919.

332. See supra notes 107-19 and accompanying text.

333. This was the view of the Collin court. See Collin, 578 F.2d at 1204-05.

334. 347 U.S. 483 (1954); see also Lawrence, supra note 246, at 439 (segregated schools held unconstitutional because they convey to African American children the message that they are part of an untouchable caste).

335. For an argument in favor of such a regulatory structure, see Note, Group Vilification, supra note 21 . 
that they avowedly seek to eradicate ideas contrary to the theory behind the law's enactment by prohibiting the dissemination of the ideas in even the most calm and rational manner. In this sense, such regulations seek to regulate what listeners im general may hear and, tlierefore, at least in part, what they may believe.

Stigma-based theories tlius seek to support the strongest possible form of regulation. If taken to their logical conclusion, such theories allow the government to prohibit one group, in this case including at a minimum white men, from believing something the government concludes is harmful to a second group, $m$ this case any of a variety of social minorities. The concept of stigma puts the potential conflict between the first and fourteenth amendments in its starkest terms: to enforce social equality, may the government prohibit its citizens from believing in mequality? Stated in more sympathetic terms, the question is whether the Constitution defends an individual's right to be a racist (or sexist or hoinopliobe). Does the Constitution forbid people from hating one another, or does it protect their right to even the most irrational hatred?

The question is the most important one we can ask in considering these issues. Racist speech and acts are in fact symptoms; they are manifestations of racist belief. As such, it is literally impossible to stamp out racist behavior coinpletely without stamping out racist ideas. And if one assumes the fourteenth amendment mandates the elimination of not only the branches of racism but also the root, the leap is not all that far to the conclusion that the fourteenth amendinent inandates the prohibition and subsequent eradication of the idea of racism. As Professor Lawrence has persuasively argued, "[t]he goal of white supremacy is not achieved by mdividual acts or even by the cumulative acts of a group, but rather it is achieved by the institutionalization of the ideas of white supremacy." 336 Similarly, as Judge Easterbrook noted in his opmion striking down Indianapohis' antipornography law as unconstitutional, the city was able rationally to conclude that "[p]ornography is an aspect of dominance. It does not persuade people so much as change them. It works by socializmg, by establishing the expected and the permissible. In this view pornography is not the idea; pornography is the injury."337 We beheve that the Constitution clearly prohibits governmental efforts to eradicate behef, no matter how repuguant a given belief may be.

Professor Lawrence does not expressly advocate such severe governmental intrusions into behef, but he does argue for premises supporting that view. It is therefore fair to test his position, and the validity of the stigma-based regulations that rely upon these premises, by examining the

336. Lawrence, supra note 246, at 442-43.

337. American Booksellers Ass'n v. Hudnut, 771 F.2d 323, 328 (7th Cir. 1985), aff'd per curiam, 475 U.S. 1001 (1986). 
constitutional validity of such intrusions. Professor Lawrence seeks to collapse the state action doctrine, which otherwise would prohibit the use of the fourteenth ainendinent to justify regulations of private conduct. Borrowing froin Professor Michelinan, Professor Lawrence argues that the doctrine, "by directing us to the text of the fourteenth amendment, diverts our attention froin the underlying issue-whether we should balance the evils of private deprivations of liberty against the government deprivations of hiberty that inay arise out of state regulations designed to avert those private deprivations."338

Although it is common to see somewhat strained interpretations of constitutional language, it is rare to confront the argument that the language of the Constitution distracts us from the constitutional issue. The fourteenth amendment does not tell us that we are entitled unequivocally to equal protection; it tells us that we are entitled to the equal protection of "the laws."339 It seeins enough to say that if one seeks to rely upon the fourteenth amendinent as the source of power to legislate equality, one is entitled to support only to the hinits of the amendment's language. When Professor Lawrence states that rehance on the state action doctrine "fails to consider that the alternative to regulating racist speech is infringeinent of the claims of blacks to liberty and equal protection,"340 he is quite right. The claims to which he refers, however, are based in morality and natural law-they are not constitutional claims, or at least not ones grounded im the fourteenth amendment. ${ }^{341}$ This dichotomy inakes sense for those who are persuaded that it is more dangerous to grant the government power over speech than it is to let people argue it out themselves. For those not persuaded, the dichotomy seems incoherent. But, as we argued earhier, there is very little to commend the idea of benevolent, neutral governmental speech restrictions.

Professor Lawrence goes on to point out, however, that his position receives indirect support from the Supreine Court's interpretation of the Civil Rights Act of 1964 in Heart of Atlanta Motel, Inc. v. United

338. Lawrence, supra note 246 , at 446 (emphasis added).

339. See U.S. CoNST. amend. XIV, \& 1 ("[N] jurisdiction the equal protection of the laws.").

340. Lawrence, supra note 246 , at 446.

341. It is not clear whether Professor Lawrence would accept a distinction between morality and natural law, and the Constitution. He argues that where women on campus are subjected to despicable racial and sexual taunts and "the University fails to protect them in their right to pursue their education free from this kind of degradation and humiliation, then surely there are constitutional values at stake." Id. at 448. There may well be, and indeed the debate on this issue tends to confirm that conclusion. The issue, however, does not arise from the severity of the injury any more than a person maimed in an accident has a claim by virtue of the severity of her wounds. If there is a constitutional issue, it must be found in generalizable principles that exist prior to the injury; any approach grounded in the severity of the pain suffered will fail to offer a principled way to resolve the question of who should bear the cost of the injury. 
States. ${ }^{342}$ According to Professor Lawrence, "[i]n upliolding the public accommodations provisions of [the Civil Rights Act], the Court implicitly rejected the argument that the absence of state action meant that private discriminators were protected by first amendment free speech and associational rights." 343 The Civil Rights Act, of course, was passed under the commerce power, ${ }^{344}$ and therefore Heart of Atlanta does not support Lawrence's point precisely. Further, because the Court in Heart of Atlanta expressly invoked a rational basis standard of review ${ }^{345}$-and although Heart of Atlanta predates United States v. O'Brien ${ }^{346}$-one suspects the Court would have reviewed the provisions of the Civil Riglits Act in greater detail had it perceived that first amendment issues were at stake. The Court's mvocation of rational basis analysis, however, was in fact a response to the assertion that the Act deprived motel owners of hiberty and constituted a taking under the fifth amendment; no first amendment issue was presented. ${ }^{347}$

Nevertheless, it is insufficient to argue, as Professor Strossen does in response to Professor Lawrence, that the Civil Rights Act focused on discriminatory conduct, not racist speech. ${ }^{348}$ It is insufficient at least if one accepts, as Professor Strossen does, the notion that all speech is one hundred percent conduct and one hundred percent speech. ${ }^{349}$ Within that paradigm, one must ask whether a given regulation is aimed at the expressive aspect of conduct, especially because we here seek to appraise an argument premised upon "the complete overlap of the idea and practice of racism."350 It seeins fairly clear that the Civil Rights Act is not directed at the expressive aspect of racisin, or at least that is what the government told the Court in Heart of Atlanta. ${ }^{351}$ Indeed, the Court specifically abjured rehance upon a Senate Committee Report that einphasized the "deprivation of personal digmity" inherent in being refused accommodations on account of race-the only arguably commumicative consideration mentioned by the Court. ${ }^{352}$

Thus, we may say that under a retroactive apphication of $O^{\prime} B r i e n$

342. 379 U.S. 241 (1964).

343. Lawrence, supra note 246 , at $448-49$.

344. U.S. CoNST. art. I, $\S 8$, cl. 3; Heart of Atlanta, 379 U.S. at 243-44.

345. Heart of Atlanta, 379 U.S. at 258-59.

346. 391 U.S. 367 (1968).

347. Heart of Atlanta, 379 U.S. at 258-59.

348. Strossen, supra note 269 , at 546 .

349. Id. at 542 n.295. This argument originated with Professor Ely. See Ely, Flag Desecration: A Case Study in the Roles of Categorization and Balancing in First Amendment Analysis, 88 HARV. L. REV. 1482, 1495 (1975) (any attempts to determine whether speech or conduct predominates will degenerate into question-begging judgments); see also Post, supra note 76, at 285 ("all '[w]ords are deeds' " (quoting L. Wittgenstein, Culture and Value 46e (P. Winch trans. 1980))).

350. Lawrence, supra note 246 , at 444 n.58.

351. See Heart of Atlanta, 379 U.S. at 252-60.

352. Id. at 250 . 
the Act was not directed at the expressive aspect of private segregation. It is equally clear, however, that although Congress was relying on the commerce clause, it was concerned not "with national commerce in any substantive sense," 353 but rather with circuinventing the state action doctrine. ${ }^{354}$ Congress might have intended to include the expressive aspects of racism. It seems unfair, then, to deprive Professor Lawrence of support for his argument simply because Congress resorted to a constitutional subterfuge to enhance the scope of the Act. Nevertheless, the Court took Congress at its word and the cases therefore do not support Professor Lawrence's analogy.

Apart from problems in finding constitutional support for his argument, however, we beheve that any attempt to focus upon philosophical justifications ultimately compels rejection of the state's ability to regulate private belief in the name of equality. Such a proposition is, to say the least, unusual within the history of the first amendment-although there have been analogous attempts to regulate belief in the naine of patriotism $^{355}$ - and the proposition in addition is diametrically opposed to the marketplace theory we sketched previously. ${ }^{356}$ Thus, there should be very strong reasons if we are to accept the position. We believe that the argument in favor of collapsing the state action argument falls short of the inark.

Professor Matsuda, however, has presented a group of alternative justifications for stigma-based regulations. Her reasoning serves prinnarily to reinforce our original skepticism. Professor Matsuda advocates state adoption of the view both that racism and, in our view, other somewhat nebulous attendant ideas are wrong, and that persons may be punished for speaking in favor of racist (and perhaps sexist or homophobic) views. ${ }^{357}$ The justification for this position is a pure appeal to truth. Professor Matsuda argues that "[w]e know, from our collective historical knowledge, that slavery was wrong. We know the unspeakable horror of the holocaust was wrong. We know white minority rule in South Africa is wrong. This knowledge is reflected in the universal acceptance of the wrongness of the doctrine of racial supremacy." 358

353. G. Gunther, Constrtutional Law 163 (11th ed. 1985) (quoting Letter from Professor Gerald Gunther to the Department of Justice (June 5, 1963) (the letter was written several weeks before Congress passed the Act)).

354. Id. at 159 (citing $A$ Bill to Eliminate Discrimination in Public Accommodations Affec/ing Commerce: Hearings on S. 1732 Before the Senate Comm. on Commerce, 88th Cong., 1st Sess. 163 (1963) (statement of the Hon. Robert F. Kennedy, Attorney General of the United States)).

355. Alder v. Board of Educ., 342 U.S. 485 (1952) (considering New York law denying employment by public school system to any person found to be a member of an organization that advocated revolution by force), overruled by Keyishian v. Board of Regents, 385 U.S. 589 (1967).

356. See supra text accompanying notes 49-68.

357. Matsuda, supra note 21, at 2380.

358. Id. at 2359. 
The initial problem with such arguments lies in figuring out who "we" are. As we saw above while examining Professor Lawrence's view of the issue, at a minimuin the speakers advocating the ideas Professor Matsuda seeks to suppress presumably disagree with her, undermining to at least some extent lier assertion of universal agreenent. What Professor Matsuda seeins to mean when she refers to "we" is that welleducated persons such as lierself who have studied the problem have coine universally to conclude that racism is wrong. Of course, the empirical support for that proposition is somewliat coniplex-one wonders whetlier the leaders of the innunierable nations thiat overtly discriminate on the basis of ethnicity are not well-educated or whetlier they have not studied the problein. ${ }^{359}$ This coniplexity is conıpounded by Professor Lawrence's persuasive description of the pervasiveness of racist beliefs in America.

Moreover, Professor Matsuda's method of supporting lier assertion of universal truth is probleniatic; seeking descriptive support for an assertion of nornative truth is both logically incoherent and soniewliat risky. What do we say about countries that practice segregation? We niay say that they are wrong, but if we are to conflate normative claims with entpirical ones, does not the existence of racist pohcies in these countries undermine the normative force of our claim? Worse yet, if the empirical evidence shows that niore people and nations are racist tlian are egalitarian, nuust we conclude tliat racism lias sonie truth to it, or even constitutes objective truth? Even if there is umiversal support for Professor Matsuda's position, the structure of lier argunient niay be seen as a classic assertion of a process-based theory of truth: We know racism is wrong because over time the opposing view lias triumplied in the global inarketplace of ideas. ${ }^{360}$

The argument is thus subject to the criticism applicable to all efforts to extract substantive truth from niarketplace notions: It is ultimately circular. Professor Matsuda denies thiat slie lias adopted a process-based tlieory of truth; ${ }^{361}$ stripped of even thit theoretical gloss her argument reduces to the proposition that she believes she is right and lier belief is strengthened by the widespread agreenient with her position. We niay agree completely with lier position, lowever, and still recognize thiat it provides no basis upon which to ground a group hibel regulation. Professor Matsuda's opinion cannot be preferred, at least by the govern-

359. South Africa is the most obvious and prominent example. Israel's treatment of the Palestinians and Arabs within its borders is often criticized as well. Less prominent states such as Sri Lanka also discriminate along ethnic lines, leading to the Tamil-Sinhalese conflict currently plaguing that country.

360. This characterization is ours, not Professor Matsuda's.

361. Matsuda, supra note 21, at 2359 n.203. 
ment, to any other position without running afoul of the reasons justifying the skepticism that animates inarketplace theory.

\section{Stigma-Based Regulations as Content-Based Restrictions}

A second point regarding group libel laws deserves inention here. As Justice Black noted in dissent in Beauharnais, group libel statutes make it extremely difficult to argue about matters of normative public concern. As he put it, "[I]n arguing for or against the enactment of laws that may differently affect huge groups, it is now very dangerous indeed to say soinething critical of one of the groups."362 Indeed, by emphasizing freedom from stigma to the apparent exclusion of other values, group libel laws pose a serious threat to the freedoin of speech, without telling us how to resolve conflicts that may arise.

Current first amendment doctrine holds that regulations may not pumish speakers for advocating a particular point of view. This doctrine contends that "[i]f there is a bedrock principle underlying the First Amendment, it is that the Government may not prohibit the expression of an idea simply because society finds the idea itself offensive or disagreeable."363 Not surprismgly, therefore, "outside the realm of low-value speech, the Court has invalidated almost every content-based restriction that it has considered im the past thirty years."364 Stigma-based regulations clearly run afoul of this doctrine, thereby adding to our list of reasons why stigma-based regulations are not constitutional.

IV

\section{Problems In Implementing University SpeEch Restrictions: The UNIVERSITY AS A SPECIAL ENVIRONMENT}

[S]tudents who support universities through tuition and who are encouraged to think of the university as their home are involuntarily forced into a position of coinphicity with racism when their campus is offered to hate groups as a forum. ${ }^{365}$

-Mari Matsuda

362. Beauharnais v. Illinois, 343 U.S. 250, 273 (1952) (Black, J., dissenting). Justice Black concluded his dissent with an appeal for a prohibition on such laws, stating that "the First Amendment, with the Fourteenth, 'absolutely' forbids [laws making it a crime to petition for and publicly discuss proposed legislation] without any 'ifs' or 'buts' or 'whereases.' " Id. at 275 . Justice Black also warned, "If there be minority groups who hail this holding as their victory, they might consider the possible relevancy of this ancient remark: 'Another such victory and I am undone.' " Id. (misquoting Plutarch's report of Pyrrhus' remarks after his victory over the Romans, Plutarch, The Lives of the Noble Greeks and Romans 325 (Brittanica Great Books ed. 1952) ("[Pyrrhus said that] one other such [victory] would utterly undo him").

363. Texas v. Johnson, 491 U.S. 397, 414 (1989).

364. Stone, Content-Neutral Restrictions, 54 U. CHI. L. REv. 46, 48 (1987).

365. Matsuda, supra note 21, at 2372-73. 
In a university knowledge is its own end, not merely a means to an end. A university ceases to be true to its own nature if it becomes the tool of Church or State or any sectional interest. A umiversity is characterized by the spirit of free inquiry, its ideal being the ideal of Socrates-"to follow the argument where it leads." This implies the right to examine, question, modify or reject traditional ideas and behefs. Dogma and hypothesis are incoinpatible, and tlie concept of an immutable doctrine is repugnant to the spirit of a university. 366

The discussion to this point has addressed speech regulations in the abstract. The regulations are, however, designed to operate in a university setting, which is both undeniably and mercifully different from a park or factory or Congress. We need to address two questions about the setting. First, how are universities different, for free speech purposes, from the world at large, and second, do those differences inatter?

Before we begin, we will explore one broader issue, that of state action. Although state universities are state actors in that they are created by the state government and receive state funds, their mission is not simply to enforce the general laws of the state. Their mission, stated most broadly, is education, and so a somewhat more sophisticated analysis is needed to appraise the constitutionality of university action than to analyze the deprivation Wilson suffered on his picket line. ${ }^{367}$ The issue may be analyzed as an unconstitutional conditions problem. Universities claim an exemption from the first amendment based on their educational mission. When a university regulates a student's speech, it claims that that restriction is necessary to effectuate its goal. For example, a university may not grade nieaningfully a series of papers, assigning some A's and some F's, without engaging in what in other circunistances would be impermissible content discrimination. The inquiry thus is twofold: whether the goal the university has chosen is a legitimate one for it to pursue as a market participant and whether the restriction of speech is related to that goal in some sufficiently close way as to pass constitutional muster. ${ }^{368}$ The second inquiry may proceed in the same way as it does in other areas where the fit between a regulation and its stated purpose is of constitutional importance. ${ }^{369}$

366. The Open Universities in South Africa 10-12 (statement of a conference of senior scholars from the University of Cape Town and the University of the Witwatersrand, including A.v.D.S. Centlivres and Richard Feetham, chancellors of the respective universities), quoted in Sweezy $v$. New Hampshire, 354 U.S. 234, 263 (1957) (Frankfurter, J., concurring).

367. See Gooding v. Wilson, 405 U.S. 518 (1972).

368. This approach is similar to the approach suggested by Professor Sunstein for unconstitutional conditions cases generally. See Sunstein, Why the Unconstitutional Conditions Doctrine is an Anachronism (With Particular Reference to Religion, Speech, and Abortion), 70 B.U.L. REV. 593, 621 (1990).

369. See Tussnian \& tenBroek, supra note 222. 
The former inquiry, however, is inore difficult. It is not enough sinply to assert, as Professor Byrne does, ${ }^{370}$ that uinversity officials are inore trustworthy than other sorts of state actors in regulating speech. There is no a priori reason to believe that this is true, and the practice under the Michigan regulation should give us long pause before we place uncritical reliance upon university administrators to be relatively nore benign despots than are politicians. We need a theory, grounded in the first amendinent, constraining the purposes for which a state university inay clain an exeniption for its speech regulations. An easy exainple would be a university that sought to teach only doctrimes espoused by the Republican or Deniocratic party. Such a prograin would be unjustifiable on purely pedagogical grounds, and would be a clear violation of the content-neutrality generally mandated by the first ainendment. ${ }^{371}$

One could niake a similar arguinent for restrictions designed to ensure civility on canipus. After all, Cohen seeins to foreclose state control of the civility of speech, ${ }^{372}$ and there are relatively few cases in which such a regulation seenis necessary to facilitate the goal for which a university claims exemption from the first ainendinent-education. Where the fit between civility regulations and education is sufficiently tight, for example in the classroon,, there would be no constitutional problem. Outside the classrooin, however, the fit seeins too loose to withstand Cohen. This argument is not necessarily compelling, however, as universities nuy choose among several competing conceptions of their nission. ${ }^{373}$ There is no constitutional reason that any of these clioices is coinpelled. We see no reason, for exaniple, why the first amendment necessarily prohibits a state from establishing a small university desigued to comfort and nurture its students in a close, comniunal environinent. We beheve, lowever, that soine choices are better than others, and that the university best realizes the true conception of its purpose when it maximizes the speech that is exclianged within its confines by reference to niarketplace primciples. The argunients set out above seek to establish the superiority of marketplace theory generally. Those below seek to establish that superiority witl specific reference to the university.

\section{A. The Argument From Student Vulnerability}

The argument regarding how we slould treat universities for free speecli purposes revolves around two ideas that arise froin diametrically

370. See Byrne, supra note 21, at 418 ("[w]hen the university proscribes a manner of speech, it is more likely that the step is taken to further valid goals of education or scholarship rather than to maintain favor with the majority who may dismiss the censor").

371. See Texas v. Johnson, 491 U.S. 397, 414 (1989).

372. Cohen v. California, 403 U.S. 15, 22-23 (1971).

373. See Post, supra note 76, at 319. 
opposed premises. The first premise holds that the university should maintain at least a minimal level of civility so that its students will not feel threatened and so be unable effectively to pursue their studies. This premise rests upon an empirical assumption that college students require such protection because, as Professor Matsuda puts it, "[n1]any of the new adults who conre to live and study at the major universities are away froni home for the first time, and at a vulnerable stage of psychological development. Students are particularly dependent on the university for community, for intellectual development, and for self-definition."374

The assumption and premise together support viewing the campus as a special environment in which racist speech should not be tolerated. Matsuda asserts:

Official tolerance of racist speech in this setting is inore harmful than generalized tolerance in the community-at-large. It is harmful to student perpetrators in that it is a lesson in getting-away-with-it that will have lifelong repercussions. It is harmful to targets, who perceive the university as taking sides through inaction, and who are left to their own resources in coping with the damage wrought. Finally, it is a harm to the goals of inclusion, education, developinent of knowledge, and ethics that uinversities exist and stand for. ${ }^{375}$

Matsuda believes that mimority group students are especially harmed because they "often come to the university at risk academically, socially, and psychologically."376 This argument covers a wide range of psychological and jurisprudential turf, but it ultimately fails to justify

374. Matsuda, supra note 21, at 2370-71. Matsuda expounds upon the vulnerability of students as follows:

The typical university student is emotionally vulnerable for several reasons. College is a time of emancipation from a pre-existing home or community, of development of identity, of dependence-independence conflict, of major decision making, and formulation of future plans. The move to college often imvolves geographic relocation-a major life-stress event-and the forging of new peer ties to replace old ones. . . A negative environmental response during this period of experimentation could mar for life an individual's ability to remain open, creative, and risk-taking.

Id. at 2370 n. 249.

375. Id. at 2371.

376. Id. Professor Matsuda bases her assertion upon statistics indicating that minorities are underrepresented in the professions and underenrolled in colleges, and suffer from higher drop-out rates than majority group students. $I d$. at $2371 \mathrm{n} .253$. She then mentions, presumably as part of her causal assertion, that minorities are not represented on law faculties in proportion to their percentage of society at large. These assertions are subject to the same objections that apply to Professor Matsuda's use of racism's relative market share.

First, if faculty composition is an alternative or additional cause of minority discomfort at universities, increasing minority discomfort by some amount, then restrictions on racist speech will not solve the problem completely, falling short by precisely this amount. Moreover, Matsuda presents no evidence that restrictions on speech will solve problems of campus racism and minority discomfort. Such regulations are both drastically underinclusive and overinclusive for that task, at levels that simply cannot pass first amendment scrutiny. At a mimimum, there is no reason to believe that regulating speech will alter the utihty of holding racist beliefs and therefore no reason to believe that regulations will address the problem underlying the mjuries Professor Matsuda seeks to remedy. 


\section{treating the campus as a special environment in which speech may be} regulated to protect students. ${ }^{377}$ The argument's empirical assumption

See supra note 252 (arguing that the suppression of racist speech will not lower the utility of holding racist behiefs).

377. But see Comment, supra note 133, at $952-55$ (universities particularly justified in protecting students because they as a practical matter cannot leave the campus). We find the increasingly frequent attempts to analogize the university to the workplace deeply disturbing. The argument, which was made in Doe v. University of Michigan, 721 F. Supp. 852, 856 (E.D. Mich. 1989), and has been around for some time in the journals, see, e.g., Note, Campus Conduct Policies, supra note 21, at 226; Note, Title VII Solution, supra, note 21, at 125 , is premised on the notion that a college education is an economic necessity in this day and age. This premise is, however, plainly false. While it is true that college graduates earn more than those without degrees, this fact is, of course, a function of the relative scarcity of college graduates. If everyone went to college, there would be no incoine gap. Yet if only a relatively few people go to college, and a college degree is necessary to prosperity, then what are we to say of the millions of people in this country who do not have degrees? It is more than a hittle demeaning to the overwhelming majority of people who have not finished college to say that they lack the "necessities" presumed to inhere in a college degree. That average incomes of college graduates exceed the average for nongraduates tells us preeisely the opposite of what the premise claims: a college degrce is not necessary, in any meaningful sense, to get along in this country. A degree may, of course, be necessary if by necessity one means relative economic wealth-a sohdly upper-middle class lifestyle. One should not wreak such linguistic havoc, however, in the name of proving something that is clearly false.

This point leads to a second, more disturbing point. The analogy assumes that people seek to maximize wealth rather than utility. This, again, is sunply false. People do not mevitably seek the employment that gives them the biggest paycheck. In employment, as in everything else, they seek those things that have the greatest utility for them, which may or may not be thc most remunerative. There are plenty of law professors who could be millionaires but who prefer a more reflective life. Such decisions are not economically irrational. By assuming people are motivated only by money, the analogy necessarily posits a purely money-based view of education. We go to college, on the analogy's account, because we want to make money. There are plenty of people, however, for whom education is its own reward, and who would attend school even without any economic incentive. Students who go into social work, public interest law, and the like, evidence similar nonmonetary motivations. The analogy between work and school cannot explain this phenoinenon. (Even if some people work because they love what they do, if economic necessity is to be equated with maximizing one's salary, as in the analogy, a worker would leave a job she loved for a less satisfying but more remunerative position.) (The Managing Editor of this law review led a life of profitable debauchery as a tour manager for rock bands, a life he gave up to work on this Comment. Only such extreme examples may be considered prima facie irrational.)

Finally, the analogy distorts the first amendment beyond all recognition. Speech in the workplace is controlled in part because work is compelled for the majority of people-workers are a true captive audience. If they leave their posts to avoid offensive speech, they will either literally be leaving their jobs or they will be fired. At this level, the analogy collapses because the economic necessity premise is patently false. At a minimum, one can graduate college without spending inuch time in public areas where offensive speecl is hikely to be found. And, as noted at infra notes 453-55, regulation of epitliets in tlie classroom (all that is "necessary" to get a degree in the strict sense) poses few first amendment problems. More to the point, however, speech regulations in the workplace serve, at least in part, to allow workers to concentrate on the job at hand without distraction. And upon closer examination, this aspeet of workplace regulations clearly differentiates the office and the classroom, at least witl respect to first amendment theory.

Workplace speech restrictions, especially those mandated (as interpreted by the courts) by title VII, clearly refect a normative judgment that certain types of speech are simply too hurtful to be vented at work. These restrictions are designed, lowever, essentially to make the workplace safe (psychologically and otherwise) for workers who might be verbally persecuted by virtue of minority status. Title VII exists to help people get work by prolibiting discrimination in hiring, and it helps them to keep their jobs by prolibiting discrimination once they are hired. A worker who is unablc to 
about the nature of college students is at best a very broad generalization, with himited applicability to many large universities which typically enroll a substantial number of graduate students, older, returning students, and other less vulnerable sorts.

We need not contest the empirical vahdity of Professor Matsuda's assumption, however, to resist her conclusion. First, students in general may well be extremely vulnerable wlien they arrive at college and, therefore, more easily traumatized by racist speech. That fact alone, however, merely describes individualized vuhuerabilities that may exist in a wide array of places-it fails to distinguish the campus from other fora except by asserting that the concentration of vulnerable people is higher on campus than in society generally. Because it fails umiquely to justify restricting speecl on campus, Professor Matsuda's assumption is largely irrelevant to her conclusion.

The same may be said of Professor Matsuda's harm-based arguinents. Matsuda first argues that the harm from racist speech on campus is more severe because perpetrators learn that they can "get away with it," presumably meaning thiat they can engage in racist speech witliout official penalty. ${ }^{378}$ Of course, persons speaking off campus learn the saine lesson, and the argument is circular to the extent that it assunies that racist speakers should be subject to official regulation-the very point at

do the job may be fired, and title VII does not apply to such a situation, even if the reason the worker cannot do the job is that she was traumatized by offensive speech on the way to the factory. (A worker traumatized by, say, racist speech at the factory might well have a claim, which is of course the source of the analogy.)

Ultimately, therefore, title VII keeps the workplace safe from speech that will inhibit an employee's ability to work. That is why the Equal Employment Opportunity Commission's guidelines on the statute (which, after all, does not itself mention speech) speak in terms of harassment that "unreasonably [interferes] with an individual's work performance." 29 C.F.R. $\S 1606.8$ (1990). This whole structure assumes, however, that the employee's job is soinething other than to consider and analyze ideas that inay be expressed in potentially offensive remarks. Otherwise the utilitarian structure of title VII folds into itself and falls apart. As argued extensively above, however, the "job" of university students (at least from the university's perspective) is precisely to confront and analyze new ideas. If those ideas are deeply offensive to the student, the university gives him the freedom to formulate a response and reject the idea. Offensiveness alone changes neither the student's nission nor the university's. The idea of restricting speech to allow a student to do his or her "job" is incoherent.

More generally, the "captive audience" rationale is of httle utility in constructing a "civility zone" around potential victims moving in public places. First, the citizens who stood to be offended by Cohen's jacket were in a courthouse hallway, Cohen v. California, 403 U.S. 15 (1971), and literally may have been compelled to be there by virtue of an arrest warrant or subpoena. As such they were far inore "captive" than a college student with access to all parts of a campus. Second, such restrictions are not content neutral: they turn on what is offensive to the listener. See Boos v. Barry, 485 U.S. 312, 320-24 (1988) (rejecting justifications of preventing offense to foreign government in striking regniations prohibiting picketing in form of embassies). To enact such restrictions would resuit in a least-conımon-denominator level of civility for everyone to protect the "individual" interest of the most sensitive listener whose "civility zone" might overlap with such speech.

378. Matsuda, supra note 21 , at 2371 . 
issue. Professor Matsuda next argues that the targets of racist speech will perceive the university as taking sides against them through inaction. ${ }^{379}$ This argunent claims, at least to sonse extent, that students will engage in a paradigm example of the fallacy of the false opposite, and there is really no good reason that speech should be regulated to prevent such imdulgence. If we are to regulate speech because a prospective audience inay interpret it through a logical fallacy, there will be little speech left at all. Additionally, it advocates the questionable tactic of preparing students to deal with what she describes as a largely racist world by shieldinig thein froni racism. We are thus left with the question of what to do with vuhrerable students offended by racist speech. The alternative to msulating them from racist viewpoints through the mechanism of speech restrictions is to inculcate the values of tolerance and intellectual self-rehance by preserving a vigorous and widely varied university niarketplace. From both a normative and a pragmatic perspective, the latter result is preferable.

Moreover, as Justice Powell has written in a soniewhat different context, "University students are, of course, young adults. They are less impressionable than younger students and should be able to appreciate that the University's pohicy is one of neutrality . . ."380 Finally, the argument fronı student vulnerability is difficult to cabm in anything reinotely resenibling a principled fashion. In essence, the argunient advocates a revival of the vision of the university in loco parentis for the narrow case of racist speech. The argunient, however, takes a faniliar form: Racist speech harms students at level $X$, and thus may be regulated for the students' own good. All external stimuli harming students at level $X$ may be regulated under this principle, and we niust now differentiate among such stimuli, a quest similar $\mathrm{m}$ forn and difficulty to our prior search for constitutive elentents of personhood. The question now is why racist speech and not obscenity or speech advocating communism or some other doctrine offensive to a given board of regents?

The problem is not clinerical, as the University of Missouri's efforts to deny recognition to a homosexual student group denionstrate. The university's rationale was precisely Matsuda's-the university first found that "[t]here are potential or latent hoinosexuals . . . who come into adolescence or young adulthood unaware that they have honiosexual tendencies."381 The university further found that "honrosexuality is an illness and should and could be treated as such and is clearly abnormal

379. Id.

380. Widmar v. Vincent, 454 U.S. 263, 274 n.14 (1981). Widmar struck down the University of Missouri's policy prohibiting religious groups from using campus facilities.

381. Board of Curators of the University of Missouri, Resolution (Nov. 16, 1973), quoted in Gay Lib v. University of Mo., 416 F. Supp. 1350, 1359 (W.D. Mo. 1976), rev'd, 558 F.2d 848 (8th Cir. 1977), cert. denied, 434 U.S. 1080 (1978). 
behavior." ${ }^{382}$ From such a base, it was only a short analytical journey to denying recognition to the student group on the ground that formal recognition would "tend to reinforce the personal identities of the homosexual members of those organizations and will perpetuate and expand an abnormal way of life."383 Worse yet, and inore pertinent to the present discussion, formal recognition would "tend to cause latent or potential homosexuals who become members to become overt homosexuals."384

This form of refutation itself should appear familiar, for it is precisely the form of argument we saw in demonstrating that process-based theories of truth are untenable. ${ }^{385}$ The conclusion there apphies here as well: Because we cannot agree upon what is true, or what should be deened to reach the threshold of harm $X$, we should prevent the government from inaking that decision for fear that it might get it wrong. The concept of normative truth is simply replaced with the concept of a normative level of harm justifying the exercise of power in loco parentis. Not surprisingly, the argument from student vulnerability also runs afoul of the principles we saw in discussing offense-based regulations-we are protecting the students from ideas, which are by definition neither true nor false. Our earher discussion does not decide the question of the umversity as a special environment, however. For Matsuda makes one final argnment, best treated as a particular vision of the university as a special marketplace of ideas.

\section{B. The University Marketplace}

Traditional first amendment doctrine holds that the university is "peculiarly the 'marketplace of ideas," "386 and that the skepticism underlying marketplace theory is at its strongest on campus. Chief Justice Warren put it best, if somewhat dramatically:

To impose any strait jacket upon the intellectual leaders in our colleges and universities would imperil the future of our Nation. No field of education is so thoroughly comprehended by man that new discoveries cannot yet be made. Particularly is that true in the social sciences, where few, if any, principles are accepted as absolutes. Scholarship cannot flourish in an atmosphere of suspicion and distrust. Teachers and students must always remain free to inquire, to study and to evaluate ... otherwise our civilization will stagnate and die. ${ }^{387}$

The urnque strength of marketplace skepticism on campus is reflected in

382. Id.

383. C. Coil, Hearing Officer's Recommended Findings of Fact (adopted by the Board of Curators of the University of Missouri, Nov. 16, 1973), quoted in Gay Lib, 416 F. Supp. at 1358.

384. Id.

385. See supra text accompanying notes $56-58$.

386. Keyishian v. Board of Regents, 385 U.S. 589, 603 (1967).

387. Sweezy v. New Hampshire, 354 U.S. 234, 250 (1956). 
the Court's application of that skepticism to offense-based regulations, holding that "the mere dissemination of ideas-no matter how offensive to good taste-on a state umiversity campus may not be sliut off in the name alone of 'conventions of decency.' " 388

This view is opposed by what Professor Matsuda refers to as "the goals of imclusion, education, development of knowledge and etlics that universities stand for."389 These "goals" lead Matsuda to conclude not only that racist speech generally may be regulated, but also that certain ideas should be demied even a classroom forum. Slie argues that "[p]oorly docuniented, racially biased work does not meet tlie professional standards required of academic writing."390 These competing visions are difficult to reconcile. Professor Matsuda's marketplace argument obviously runs headlong into the problems with stigma-based regulations that we discussed above. Still, there is a strong intuitive pull in the notion that the campus is different from society at large, and that we should preserve tliat difference. We behieve, liowever, that Professor Matsuda mistakes the way in which universities are, and should be, different from the rest of society.

The umiversity marketplace is different froin tlie marketplace in society at large because the umiversity cominumity exists to consider a inucl wider range of ideas in much greater deptll. These differences separate the umiversity from political debate, workplace debates, and inass media. $^{391}$ The animating features of the university community are tlie mutually reinforcing values of tolerance and skepticism. They alternatively allow and inspire investigation and intellectual innovation; wliere they are constrained, the commumity is to that extent weakened. This view comports witl the Court's current view of the university-and probably with the aspirations of most university conmunities. We also beheve tliat it is a desirable vision, and we may see this by returning to Professor Matsuda's vulnerable students. When a student confronts a highly offensive, degrading instance of speech, wliat is she to do? The marketplace theory we advocate liere tells her, in essence, to listen to the speech and formulate rational, coinpelling responses. She must then place those responses in the same marketplace and fight for tliem until tliey are accepted. ${ }^{392}$

388. Papish v. University of Mo., 410 U.S. 667, 670 (1973) (citing Healy v. James, 408 U.S. 169, 192-93 (1972)).

389. Matsuda, supra note 21 , at 2371.

390. Id. at 2365.

391. Geraldo on Habermas is an experience we will undoubtedly (and mercifully) be spared.

392. A corollary of this argument is that the best way to combat racism in society as a whole is to disprove its premises through open discussion. The argument applies analogously to racist speech and invective. As Professor Farber puts it:

[O]ffensiveness is often an important part of the speaker's message. Use of offensive language reveals the existence of something offensive and ugly, whether in the situation 
The campus debate over offensive speech has not been limited to the speech of students or outside speakers, but has come to include questions of professorial classroom speech as well. Two recent incidents from the Berkeley campus of the University of California should serve to frame the problem. The Fall 1990 class reader for Environmental Design I contamed excerpts from a work by Wallace Stegner. ${ }^{393}$ The passage included the word "wetback," used as a reference to Mexicans who had entered the United States im apparent violation of apphicable immigration laws. ${ }^{394}$ Some students in the class (and later students not in the class) were offended by the use of the term and criticized the instructor for his insensitivity for including them in the first place. ${ }^{395}$

Later that same terni, a group of approximately fifty students held a demonstration during an anthropology class taught by Professor Vincent Sarich. ${ }^{396}$ Many, if not most, of the students apparently were not enrolled in Professor Sarich's class at the time. ${ }^{397}$ The students objected to statenients pubhished by Professor Sarich (and related inforniation taught in the course) which attempted to draw a statistical correlation between differential male/female cramal volume and differential male/ female perfornance on standardized tests. ${ }^{398}$ The demonstration succeeded in preventing further instruction that day, in spite of vociferous objection to the demonstrators voiced by at least some of the students enrolled in the class. ${ }^{399}$

Between them, these incidents implicate two of the core concerns of acadermic freedom: freedom of research and freedom of teaching. ${ }^{400}$ If offensive speech restrictions (or equivalent standards adopted by faculty review panels) ${ }^{401}$ are read to cover the classroom speech or research pubhications of professors, the imphications for the university could go beyond even those flowing from restrictions on student speech. Bearing in mind John Searle's warning that many supposedly dire campus trends

described by the speaker or in the speaker's mind itself. . . Suppressing this language violates a cardinal principal of a free society, that truths are better confronted than repressed.

Farber, Civilizing Public Discourse: An Essay On Professor Bickel, Justice Harlan, and the Enduring Significance of Cohen v. California, 1980 DUKE L.J. 283, 302.

393. Jennings, Racial Slur Found in Course Reader, Daily Californian, Oct. 23, 1990, at 1, col. 3. The excerpts were from Stegner, Striking the Rock, THE AMERICAN WEST AS LIVING SPACE (1987).

394. Jennings, supra note 393 , at 1 , col. 3 .

395. Id. at 7, col. 3-4.

396. Miller, Students Clash in Anthro, Daily Californian, Nov. 8, 1990, at 1, col. 1.

397. Finseth, Sarich an Eclectic by Nature, Daily Californian, Dec. 7, 1990, at 3, col. 1.

398. Miller, supra note 396 , at 11 , col. 1 .

399. Id. at 1, col. 1, 11, col. 1 .

400. Metzger, Profession and Constitution: Two Definitions of Academic Freedom in America, 66

TEX. L. REv. 1265, 1269 (1988).

401. See infra text acconpanying notes 419-20. 
are merely silly, not catastrophic, ${ }^{402}$ this Section will nevertheless examine what limitations, if any, academic freedom places upon restrictions of professorial speech. In order to do so, we must examine the primary justifications for, and implementations of, academic freedom in American universities.

It is important to note at the outset that there are two operational conceptions of academic freedom in the United States. The first is the conception held within the academy, and enforced primarily within a given umiversity or within the profession as a whole, which tends to focus on the rights of the individual academic. ${ }^{403}$ The second is the conception adopted by the courts, which focuses upon the freedom of the institution agamst other societal actors, includimg courts theinselves. ${ }^{404}$ We will refer to the former as the professional conception, the latter as the legal conception. Academic freedom in the United States imitially derived from the model that flourished in Germany during the nimeteenth century. ${ }^{405}$ The German model covered two primary activities: research and teaching. The concern was that the development and dissemination of knowledge not be limited by social forces (usually the government or the church) external to the university. ${ }^{406}$

As American universities began to spring up im ever-increasing numbers during the nineteenth century, they generally were structured on a corporate model: Established by a charter or trust, they were managed by a President who was appoimted by, and in turn ultimately answerable to, a board of trustees. Professors formally were the employees of the institution, and so were subject to the same legal rules as the employees of any other firm. Most importantly, they could be fired at will. 407

Against this background, it is apparent why the first formal effort to define and implement a coherent and nationwide policy on academic freedom im the United States took pains to put forth an alternate view of the relation between the university and the individual professor. The American Association of University Professors (AAUP) issued its first

402. Searle, The Storm Over the University, N.Y. Rev. of Books, Dec. 6, 1990, at 34, col. 2.

403. See generally Metzger, supra note 400, at 1276-77; Byrne, Academic Freedom: A "Special Concern of the First Amendment," 99 YALE L.J. 251, 255 (1989); see infra notes 408-20.

404. See Byrne, supra note 403, at 255 (academic freedom sometimes used to refer to the freedom of the university as corporate entity against the state).

405. Metzger, supra note 400 , at $1270-71$. The German conception included three freedoms: for the university, the professors, and the students. For reasons that are beyond the scope of this Comment, only the first two survived the journey to our shores, and the rights of students have never been included in any working definition of "academic freedom" as used in this country. Id. at 1269 . 72.

406. Id. at $1269-72$.

407. Rabban, Does Academic Freedom Limit Faculty Autonomy?, 66 TEx. L. REv. 1405, 1413 (1988). 
Principles of Academic Freedom in 1915, and the conception there articulated was and remains the foundational and most eloquent (if not most recent) statement of the professional conception of academic freedo1n. ${ }^{408}$ The AAUP put forth the idea that even private universities were not, for the most part, truly private concerns. ${ }^{409}$ Instead, the Declaration argued, they were entrusted with a public mission: the advanceinent of knowledge in all its forms, and through that advance the advancement of the republic as a whole. ${ }^{410}$ In short, uriversities were to carry out the project of the Enlightenment. This, however, required that the profession make a decision as to how such an advance was best to be achieved.

The 1915 Declaration clearly commits the AAUP to what was in essence the marketplace theory of truth. ${ }^{411}$ The Declaration is for the most part phrased in the language of science, reflecting the prevailing view of the day that most disciplines were "sciences" of one sort or another. ${ }^{412}$ In such disciphines, the goal was to inove ever closer to a simgle, objective, and ultimately knowable truth. ${ }^{413}$ With knowledge so conceptualized, the profession's commitment to inarketplace theory is readily understood: As long as the search for truth proceeds according to commonly agreed on principles, such as standards of verifiability, ability to be reproduced, and rules of proof, error can be detected, and corrected, in a relatively efficient way. The consequence is that the AAUP rejected any attempt institutionally to define truth. ${ }^{414}$ Truth is, of course, never considered conclusively established. It is always open to challenge and possible refutation.

The individual freedom required by the marketplace inodel was clearly inconsistent with a relationship based on master-servant principles. Instead, the umiversity administration and the board of trustees were viewed as trustees in a inuch stronger sense: holders of a trust from the public as a whole, a trust dedicated to the idea of free inquiry into the truth. ${ }^{415}$ Professors, in turn, were viewed not as employees in the traditional sense, but rather as appointees, who should hold their appointinents during good behavior. ${ }^{416}$ The academy had come to conceive of

408. The most recent comprehensive AAUP statement is the 1940 declaration of principles. Both statements are reprinted in ACADEMIC FREEDOM AND TENURE (L. Joughin ed. 1967) [hereinafter ACADEMIC FREEDOM], with the 1915 version at page 155 and the 1940 version at page 33.

409. Id. at 160 .

410. Id. at 161; see also Rabban, supra note 407, at 1409.

411. See supra text accompanying notes 49-68.

412. ACADEMIC FREEDOM, supra note 408, at 164-65.

413. Id. at 164 .

414. Metzger, supra note 400 , at 1274,1320 .

415. Id. at 1279.

416. ACADEMIC FreEdom, supra note 408, at 156. The 1915 Declaration draws an explicit analogy to federal judges. Id. 
itself as a profession, properly subject only to self-regulation.

Self-regulation ${ }^{417}$ was and remains one of the keys to the implementation of the professional view of academic freedom. Decisions as to hiring, proinotion, and evaluation are to be inade by faculty committees. ${ }^{418}$ While those decisions are subject to approval by various levels of the university administration, ${ }^{419}$ culminating in the board of trustees, the professional view of academic freedom contemplates that such actors should only rarely, in the inost extreme of circumstances, overturn the decisions of the peer review coinmittee. ${ }^{420}$

The legal conception of academic freedoin is generally stated in terms of the "four freedoms" of umversities, froin a statement by South African universities quoted by Justice Frankfurter in his concurrence in Sweezy v. New Hampshire:421 The right of the university "to determine for itself on academic grounds who inay teach, what may be taught, how it shall be taught, and who may be admitted to study."422 The relationship between the academic mission and the university's restrictions on speech is what justifies its claim of exemption froin the strictures of the first amendment. ${ }^{423}$ The values underlying this freedom are that universities are the prime players in the disinterested (that is, unbiased) search for knowledge, that they foster a inethod of thought and discourse conducive to that search, and that they instill such capabilities in others, who in turn carry those values into society.

The necessary consequence of this is that the legal conception of academic freedoin does relatively little to protect the interests of individual professors, as opposed to institutions. ${ }^{424}$ If the goal is to maximize institutional autonony and minimize intrusion by the government, the fact that courts are part of the governinent limits the extent to which they can substitute their judgement for the choices of the institution. Thus, courts generally do not characterize the claims of individual professors as "academic freedoin" claims, preferring instead to resolve

417. This is generally known in the trade as peer review.

418. Rabban, supra note 407 , at $1410-11$.

419. Id. at 1411. It is important to remember that most members of the administration will also be academics in their own right, and so should have professional interests partially balancing their institutional ones.

420. Id. at 1412. Even Marxist critics of the American implementation of academic freedom seem to agree that peer review is a tolerable device. See e.g., Piven, Academic Freedom and Intellectual Dissent, in REgulatiNg THE INTELlectuals 21 (C. Kaplan \& E. Schrecker eds. 1983).

421. 354 U.S. 234 (1957).

422. Id. at 263 (Frankfurter, J., concurring) (emphasis added).

423. See supro notes $365-70$ and accompanying text.

424. Cf. Metzger, supra note 400 , at 1291 ("the . . 1915 report did not find a close friend in the first amendment"); see also Byrne, supra note 403, at 255 (arguing that while the "non-legal tradition of academic freedom has been directed at protecting . . . the individual professor," the legal conception "should primarily insulate the university from interference by the state"). 
such claims under general first amendment analysis. ${ }^{425}$

Applying the different conceptions of academic freedom to the problein of potentially offensive professorial speech yields differing results. The legal conception probably would prohibit certain express limitations imposed by a board of regents or president, but quite possibly ouly if imposed on the subject inatter of a class or course of research. In any case, such restrictions imposed by an administration nornally would be opposed vigorously by the faculty and peer review organs within a university. The real problem occurs when precisely those organs, usually the guarantors of the rights of individual professors, becoine the actors who either imitiate or acquiesce in the restriction on faculty speech. If, as was the case with the situation involving Professor Sarich, there was a possibility not only of disciplinary action against a professor, but disciplinary action taken by a faculty committee, ${ }^{426}$ there is hittle that courts would be willing to do to intervene. The issue thus collapses to a normative one: how ought peer review committees judge cases involving allegations of offensive speech on the one hand, and academic freedom on the other?

The issue in large measure returns to the goals of the university, the preferred method for achieving those goals, and so to inarketplace theory. There is hittle we can add here to the discussion of marketplace theory given above. A peer review comınittee should be mindful of its role as the internal guarantor of professional autonomy. Thus, when faced with a case involving what Professor Matsuda has termed "[p]oorly documented racially biased work," 427 a peer review committee should take care to ensure that its judgment is based solely on the first, and not the second, set of objectives.

\section{The University as a Public Forum}

Public forum doctrine is relatively recent, and has been characterized by confusion regarding botli its foundations and apphication. ${ }^{428}$ The doctrine states that certam places and resources controlled by the goverument are public fora, where speech will receive the full protection of the first amendment, whereas other places and resources controlled by the goverument are not. These latter places are more

425. Metzger, supra note 400 , at 1319 .

426. Finseth, supra note 397 , at 3, col. 1 .

427. Matsuda, supra note 21, at 2365.

428. See Post, Between Governance and Management: The History and Theory of the Public Forum, 34 UCLA L. REV. 1713, 1715-16 (1987). 
analogous to private property ${ }^{429}$ where speech may be restricted. ${ }^{430}$

The doctrine was born in Hague v. CIO, ${ }^{431}$ in which the Court struck down an ordmance requiring a permit for public parades or ineetings in streets and parks. ${ }^{432}$ Acknowledging that the government owned the land in question, and that a private landowner could restrict speech on his property at will, the Court concluded that the government held public streets and parks in trust for the people, and that these streets and parks have been devoted to expressive activity from time immemorial. ${ }^{433}$ Such a simple formulation quickly ran into trouble, ${ }^{434}$ however, and in recent years the Court has refined the forum inquiry to focus on the primary purpose of the government institution at issue and on the compatibility of first amendinent activity with that purpose.

In Cornelius v. NAACP Legal Defense and Educational Fund, Inc., ${ }^{435}$ for example, the federal government sought to exclude all advocacy organizations from the Combimed Federal Campaign, or CFC..$^{436}$ The Court concluded that although the CFC took place in a public office, the government intended to facilitate the raising of charitable donations, while minimizing the accompanying disruption of the federal workplace. ${ }^{437}$ Findimg that both goals would be thwarted by allowing advocacy organizations to jom the CFC, and finding no intent on the part of the government to open the federal workplace to all speech, the Court held that the CFC was not a public forum. ${ }^{438}$ Thus, the public forum doctrine examines the primary mission of the government institution,

429. See id. at 1758-64 (describing in detail the state of the doctrine). A refinement of the doctrine, stating that in some circuinstances private property will be considered to have become a public forum, would be relevant to the treatment of private universities. In an attempt to preserve the umitary treatinent of public and private campuses, we will not pursue that distinction here.

430. If the govemment property is found to be a public forum, any content-based restriction on speech will be subject to strict scrutiny. Umited States v. Kokinda, 110 S. Ct. 3115, 3119 (1990) (plurality opinion) (holdmg sidewalk outside post office not traditional public forum). Even if the Court finds the property a nonpublic forum, the state is still limited to imposing restrictions in a viewpoint-neutral inanner. Comelius v. NAACP Legal Defense \& Educ. Fund, Inc., 473 U.S. 788, 806 (1985) (reinanding for inquiry into viewpoint-neutrality of otherwise permissible regulation in a nonpublic forum).

431. 307 U.S. 496 (1939) (plurality opinion).

432. Id. at 516 (ordinance requiring permit for public parade or nueeting void on its face because it allows for "arbitrary suppression of free expression of views on national affairs").

433. Id. at 515 .

434. Compare United States v. Grace, 461 U.S. 171, 178-80 (1983) (finding public sidewalk in front of Supreme Court to be a public forum) with Greer v. Spock, 424 U.S. 828, 835-37 (1976) (finding public streets and sidewalks within military base not a public forun).

435. 473 U.S. 788 (1985).

436. Id. at 790 . The CFC is the annual charitable fundraising drive within federal govemment offices; it is carried out by government eniployees on goverument time. Id.

437. Id. at 805 .

438. Id. at 804-06. Similarly, in Perry Edueation Association v. Perry Local Educators' Association, 460 U.S. 37 (1983), the Court found that by providing an interoffice mail system for its teachers, the school district had not created a public forum coinpelling it to allow all groups to use 
and only permits regulation of speech that is fundamentally incompatible with that mission. ${ }^{439}$ If we use this approach to imquire whether universities are public fora, we must look first to the traditional role the university has played. The language the Court has chosen in the past indicates that it views campuses as crucially involved in the marketplace of ideas. ${ }^{440}$ This view supports the conclusion that a university campus is in fact a pubhic forum.

The language of past holdings on campus speech suggests that the Court has traditionally viewed universities as unique locations where speech plays a heightened role and thus where the interchange of ideas, even offensive ideas, receives full first amendment protection. ${ }^{441}$ The Court has spoken of "the . . . significant interest in the widest latitude for free expression and debate consonant with the mamtenance of order." Moreover, the Court emphasized that the first amendment does not allow for standards based upon the content of speech. ${ }^{443}$ Instead, the Court stated, the first amendment was particularly committed to protecting academic freedom, ${ }^{444}$ for the classroom "is the peculiarly 'n1arket-

the mail system. Id. at 46-47. Furthermore, the Court found that such access would be inconsistent with the purpose of the system. Id. at 49-52.

439. Note that this does not displace completely the inquiry into the traditional use of the government institution. Where the institution has long been used for speech purposes, for instance, a government claim that speech is suddenly incompatible with the institution properly may be viewed with skepticism. Similarly, we may cousider the Court's "limited" or "designated" public forun doctrine as a subset of the overall purpose inquiry. "Limited" or "designated" public foruns are those which traditionally have not been used for free speeeh purposes, but which the government is found inteutionally to have opened to speech. Cornelius, 473 U.S. at 802; Perry, 460 U.S. at 45. Government regulation of speech im a limited or designated forum is subject to the same constraints as regulation in a traditioual public forum. Perry, 460 U.S. at 46 . That the governinent intentionally opened an institution for speech can best be seen as creating a presumption that speech is not incompatible with the imstitution's purpose. Should this presumptiou prove inaccurate, the government can close the institution to speech, but it must do so on a reasonable basis. See United States v. Kokiuda, $110 \mathrm{~S}$. Ct. 3115, 3119-20 (1990) (plurality opinion) (regulation of speech on property that government has not dedicated to speech tested under the rule).

440. The special role of the university was first discussed in Sweezy v. New Hampshire, 354 U.S. 234 (1957). Although the case involved a professor who challenged questions put to him at a loyalty hearing, and the case was decided on due process grounds, the plurality opinion included a paragraph-long encomium on the virtues of the university. Id. at 250. The concurring opinion, quoting from a South African plea for academic freedom, was similarly impressed with the importancc of unfettered speech on college campuses. Id. at 262-63.

441. See, e.g., Papish v. Uuiversity of Mo., 410 U.S. 667 (1973) (student on campus distributed uewspaper containing offensive headline and cartoon); Healy v. James, 408 U.S. 169 (1972) (studeuts wishing to organize local chapter of Students for a Democratic Society (SDS) denied recognition and access to campus facilities); Keyishian v. Board of Regents, 385 U.S. 589 (1967) (professors sued to enjoin application of state statute requiring dismissal of any employee who was member of "subversive" organization, whether or not employee intended to carry out aims of organization).

442. Healy, 408 U.S. at 171.

443. Papish, 410 U.S. at 671 ("the First Amendment lcaves no room for the operatiou of a dual standard in the academic community with respect to the content of speech").

444. Keyishian, 385 U.S. at 603 ("Our Nation is deeply committed to safeguarding academic 
place of ideas." "445

The Court provided a final gloss on the question of the university as a public forum in Widmar v. Vincent. ${ }^{446}$ In Widmar, the Court was faced with a challenge to a University of Missouri policy that denied use of canıus facilities to groups ineeting for religious purposes while allowing their use by secular campus groups. ${ }^{447}$ The Court held that the university had created a public forum "open for use by student groups" by opening its facilities generally to sucli groups. ${ }^{448}$ The canıpus' status as a public foruin in turn subjected to first anendinent scrutiny any university policy that restricted use. ${ }^{449}$ Thus, tlie Court's holding linked a marketplace model of the university with content-based constitutional standards. It tlierefore appears that even inanagerial authority ${ }^{450}$ las limits when that authority seeks to restrict speecl because of the ideas tlie speecli contains. The exercise of sucl authority is valid only insofar as it serves to facilitate the inarketplace. ${ }^{451}$

The analysis is clearest when the area in question is a campus plaza, commons, or quad. Sucli a space closely reseunbles the traditional "speaker's corner" of a public park. More importantly, it is a speaker's corner for a community whose primary imssion is best carried out through n1aximizing tlie excliange, discussion, and investigation of ideas. The pliysical cliaracteristics of sucli an area are another iunportant factor in determining whether it is a public forum. Such open spaces allow students to move freely froin one conversation to another, or to avoid debates altogetlier. Speakers and listeners are not subjected to speech they cannot avoid. ${ }^{452}$ Sucli cliaracteristics, as well as the voluntary participation of tlie speakers and histeners involved, provide the sort of "buffer zone" that inakes it likely tliat different sensibilities and points of

freedom [which is] a special concern of the First Amendment, which does not tolerate laws that cast a pall of orthodoxy over the classroom.").

445. Id.

446. 454 U.S. 263 (1981).

447. Id. at 265 .

448. Id. at 267.

449. Id. at 267 n.5 (quoting Healy v. James, 408 U.S. 169, 180 (1972))

450. Professor Post uses the term "managerial authority" to describe the exercise of the government of its power to limit speech inconsistent with the primary purpose of an institution. Post, supra note 428, at 1717 (stating that government's inanagerial authority allows it "constitutionally [to] regulate speech as necessary to achieve instrumental objectives").

451. See id. at 1799 ("government action withm organizational domains is at times designed for the specific purpose of facilitating symbolic interaction, as occurs . . . in . . . universities"); id. at 1834 n.402 ("Special environments like universities may constitute an exception to this generalization, since in such environments the culture of academic freedom miglit instrumentally connect a tradition of public access for expressive purposes with the achievement of educational objectives.").

452. See Cohen v. California, 403 U.S. 15, 21 (1971) (dismissing argument that state has interest in protecting sensitive viewers in courthouse lallway when the viewers could "avert[ ] their eyes" or move away). 
view can be accommodated. ${ }^{453}$ To limit ${ }^{454}$ speech in such a location would run counter to both the traditional physical conception of a public forum and the educational mission of a university.

While the analysis may appear more complicated in the classroom, neither forum analysis nor marketplace theory ultimately supports a conclusion different from the one we reached above. Although the physical characteristics of a classroom certainly differ from some traditional public fora, they by no means preclude tlie conclusion that the classroom is also one. The classroom is at the core of the educational mission of the university. It is where ideas are not merely exchanged, but are subjected to reasoned inquiry. Appeals to emotion have less place there than on a soapbox. This means that an erroneous idea expressed in class is likely to meet searching scrutiny and be effectively disproved. Moreover, the classroom is the primary place for students to acquire the tools necessary to disprove, as opposed merely to disagree witl, racist assumptions. The success of this endeavor may be less certam, and certainly less fully tested, if those in the classroom cannot dissect offensive assumptions out loud.

Most of the objections to "free speech" in a classroom can in fact be expressed as time, place, and manner limits. When a professor decides which students to recognize, and in what order, slie simply is using a precedence system that varies only slightly froin the "first come, first served" method. The fact that students are expected not to conduct an argument by screaming at one another reflects a straightforward manner linitation on volume. ${ }^{455}$ The key is that a professor could not consistently refuse to call on a student because she disagreed with the student's views, or allow some students to yell while requiring others to whisper. In such an event the professor would be imposing speech restrictions unrelated to the academic mission, and thus would forfeit the university's claim to be exempt from the first amendment. These traditional understandings of the proper functioning of a classroom reflect the classroom's purpose as a forum for the interchange of ideas. The classroom resembles a market under perfect conditions-it exists for the introduction and exchange of ideas, not for their inculcation.

The most coinplicated situation is presented by residence halls. The umiversity is generally the owner, but residence halls are also, at least in part, private living spaces for the students who occupy them. Tradition-

453. See generally Post, supra note 294; see also supra notes 49-68 and accompanymg text.

454. By "limit" we mean a content-based limitation. We assume that a true time, place, and manner limitation (for example, limiting the times of day that amplification equipment can be used, or mitiating a precedence system) would be as valid on a university campus as anywhere else.

455. See Ward v. Rock Against Racism, 491 U.S. 781 (1989) (upholding sound amplification restrictions on concerts in New York City's Central Park as valid place and manner restrictions). 
ally, private homes have been viewed as enclaves which to some extent displace the first amendment. ${ }^{456}$ This means that, at the very least, a unversity could restrict the right of one student to enter another's room. The university most likely could also discipline a student who posted material on another student's door, simce such speech would be directed at the personal residence of the affected student. ${ }^{457}$ The common living spaces of a dormitory (for example, the lounges, restrooms, and recreation halls) present a more difficult problem, but one that ultimately can be solved through an examination of the physical characteristics and purposes of the specific areas. Lounges in which students hold open discussions, meetimgs, and the like are probably public fora, while dormitory study halls devoted to sohtary reading probably are not. Even in those spaces that are not traditional public fora, restrictions on speech must conform to the limits of viewpoint-neutrality. ${ }^{458}$

The determination that the vast majority of space on a university campus is a public forum is consistent with the general rationale of the "marketplace of ideas." Marketplace theory works best where inquiry can be full and where values of rationality apply. ${ }^{459}$ To the extent that our society is committed to the arguinent from truth, the university is "pecuharly" the marketplace of ideas in part of necessity: If reason cannot be expected to prevail in such a setting, it cannot be expected to prevail anywhere.

This view of the role of the campus clashes with Professor Matsuda's view that the campus has a special obligation to restrict racist speech because its students are especially vulnerable. First, because the structure of classroom debate makes it more likely that no opinion will go unchallenged, if we are confident that racist ideas are insupportable, then the uriversity would seem the ideal place to have thein aired and disproved. Second, if, as Professor Matsuda says, education and the development of knowledge are among the goals of the university, then it seems anomalous to adopt a policy that is both at odds with that development through the marketplace of ideas and stifling to the education of persons who hold false views-who, at least in Professor Matsuda's eyes, are presumably in the most desperate need of education. If the university

456. See, e.g., Frisby v. Schulz, 487 U.S. 474, 483-84 (1988) (upholding local ordinance limiting demonstrations on public sidewalks outside private homes in part because of the privacy interests inherent in the home); FCC v. Pacifica Found., 438 U.S. 726, 748 (1978) (allowing limits on indecent radio broadcasts in part because they reach into private homes).

457. See Pacifica, 438 U.S. at 748 (upholding limit on speech uttered in a public forum but directed at a private home).

458. Cornelius v. NAACP Legal Defense \& Educ. Fund, Inc., 473 U.S. 788, 806 (1985) (holding that in regulating access to a nonpublic forum, government may not distinguish on the basis of viewpoint).

459. F. SCHAUER, supra note 59, at 26 ("In systems of scientific and academic discourse, the argument from truth has substantial validity."). 
is a public forum, the main conclusion we can draw is that the first amendment applies with full force on campus. This serves to negate arguments by proponents of offensive speech regulations that the cainpus should adopt special measures against offensive speech. It does not prevent the campus from taking action consistent with the first amendment, lowever, to limit nonpublic discourse that would not otherwise qualify for first ainendment protection. ${ }^{460}$

\section{CONCLUSION}

University restrictions upon offensive speecl may be divided into three categories. The first includes regulations designed and tailored to prevent speech that will provoke a violent response. Such regulations are constitutional under the "figliting words" exception. The second category includes regulations designed and tailored to prevent private speech that severely offends listeners; this category includes a very narrow range of speech tliat is not inherently likely to provoke a violent response and is not addressed to a topic of normative or descriptive public concern. Sucli regulations are constitutional because the relevant speech implicates constitutional values at a very low level. Other types of offensebased regulations, however, are unconstitutional. The third category includes regnlations designed to protect members of a protected class from stigma. Such regulations are unconstitutional because the offense they seek to regulate arises from the ideas a speaker expresses, ideas that may not be deemed false without violating the skeptical premises of marketplace theory.

To say that the government may not regulate speecl is not to say that it must stand idly by im the battle to achieve true equality for the members of social minorities in this country. Rather, the government should vigorously condemn racism and inequality, but as a market participant ratlier thian as a market regulator. As Professor Strossen has suggested, "[a]11 government agencies and officers, including state university officials, sliould condemn slavery, de jure segregation, and otlier racist institutions that tle government formerly supported."461 Universities may also, within reason, use their power over curriculum to enhance

460. As Professor Charles Wright stated in his landmark article, "I fully share the view ... that the life of a university depends on 'the pursuit of truth and knowledge solely through reason and civility, and that lack of civility leads only to a harmful polarization of opinion, but it is perfectly clear that the first amendment did not enact Mrs. Emily Post's book of etiquette." Wright, The Constitution on the Campus, 22 VAND. L. REv. 1027, 1057 (1969) (quoting CRISIS AT Columbia: REPORT OF THE FACT-FINDING COMMISSION APPOINTED TO INVESTIGATE THE DISTURBANCES at Columbia University in APRil AND MAY, 1968, at 196 (1968)).

461. Strossen, supra note 269, at 562; see also Post, supra uote 76 , at 314 (discussing government actions short of restrictions on public speech that would have the effect of welcoming minorities into the public discussion). 
students' awareness of the history and present concerns of social minorities. The government's power in this regard is not unlimited. In the economic market, the government would not be immune, in its capacity as market participant, from the antitrust laws; a similar constraint would prevent the government from seeking to monopolize the marketplace of ideas. ${ }^{462}$ Nevertheless, the government should participate vigorously in the market.

Students are not without recourse to market forces either. There is currently a national debate over the rise of so-called "politically correct" behefs and the efforts of students in universities to advocate such beliefs in their schools. ${ }^{463}$ While marketplace theory prohibits the government from adopting regulations enforcing the students' beliefs as true, the students' vigorous efforts to prevail over what they see as the predominant value structure is precisely the type of no-holds-barred competition envisioned by marketplace theory. The degree to which "political correctness" has come to be a subject of widespread contention in the mass media and on campus seems to belie the contention that racist and other "incorrect" speech disables members of social minorities from participating in robust debate and political self-determination. "Politically correct" behefs may or may not prevail, but to the extent the debate takes place in a free marketplace, all concerned will be the better for it, regardless of the outcome.

462. See, e.g., City of Columbia v. Omni Outdoor Advertising, Inc., 59 U.S.L.W. 4259, 4262 (Apr. 1, 1991) (local government acting in its regulatory capacity is immune from antitrust laws); Shiffin, Government Speech, 27 UCLA L. Rev. 565, 587 (1980). This, of course, says nothing about how aggressively the government may compete in an otherwise private and competitive market.

463. See, e.g., Ruley, What's Correct About Campus PC?, Wash. Post, Feb. 3, 1991, at C1, col. 1 . 